\title{
An Analysis of Modern Public Administration in the Context of Policy-Making Cycle (Case Study)
}

Mehrdad Bozorguinezhad ${ }^{1}$ Ph.D Student, Department of Public Administration, Faculty of Management and Economics, Science and Research Branch of Islamic Azad University, Tehran, Iran.

Gholamreza Me'marzadeh Tehran ${ }^{2}$ Associate Professor, Department of Public Administration, Faculty of Management and Economics, Science and Research Branch of Islamic Azad University, Tehran, Iran (Corresponding Author).

Abolhassan Faghihi ${ }^{3}$ Professor, Department of Public Administration, Faculty of Management and Economics, Science and Research Branch of Islamic Azad University, Tehran, Iran.

\begin{abstract}
One of the important success factors in public sector organizations is voluntary participation or citizen-centered approach which is emphasized by modern public administration paradigm. The purpose of this research was to introduce the modern public administration paradigm and to emphasize the vital role of modern public administration dimensions as the predisposing factors of citizens' participation in the policy-making cycle of Tehran Municipality. A matrix was made up of modern public administration dimensions and steps of policy-making cycle drawn respectively on the $\mathrm{X}$-axis and Y-axis of the Cartesian coordinate system so that the importance and priority of citizens' participation could be determined at the interception point of the matrix. Then, a conceptual model was developed based on targeted sampling method involving 10 experts and applying fuzzy Delphi technique in two phases and with structured interviews. Besides, 392 questionnaires were distributed among the staff personnel of the municipality, selected through random sampling method. Results show that participation affects policy-making cycle through one-way communication, dialogue and deep conversation in six phases; through social counseling in five phases and through work sharing in three phases. Also, modern public administration dimensions have positive impact on policy-making cycle through the four types of participation, meaning one-way communication, social counseling, dialogue and deep conversation and work sharing.
\end{abstract}

Keywords: Modern Public Administration, Public Policy-making, Public Policy-making Process, Citizen-centered Approach, Citizens' Participation.

1. bozorginejad@tehran.ir

2.govmanagement@srbiau.ac.ir

3. A.faghihi@srbiau.ac.ir 


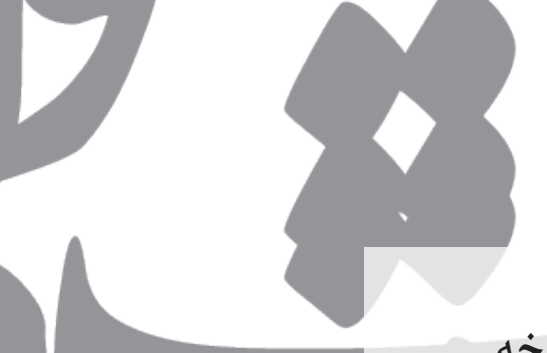

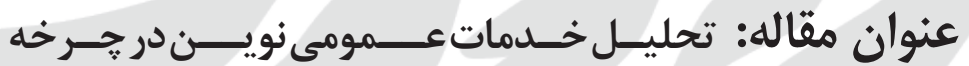
خطمشى كذارى (مطالعهموردى)

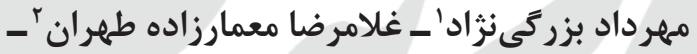

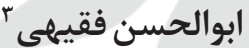

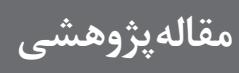

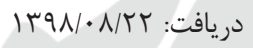

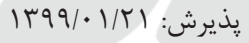

\section{جكيu:}

از عوامل مهمم موفقيت سازمانهاى بخش دولتى مشاركت داوطلبانه و شهروندمحورى مارى

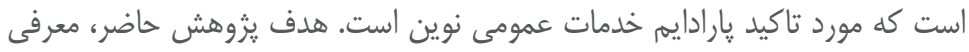

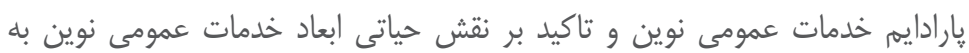

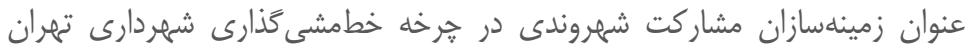

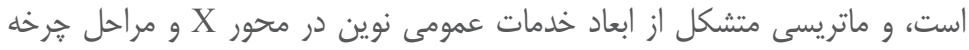

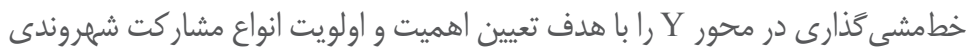

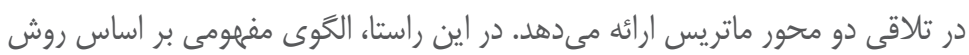

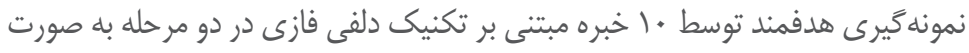

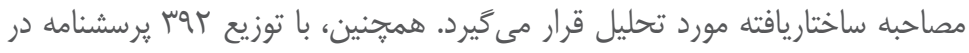

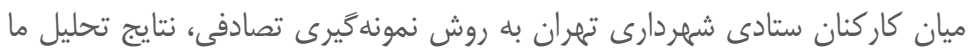

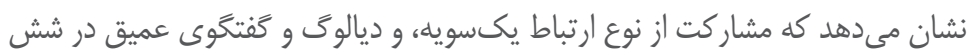

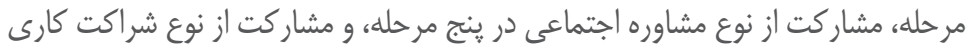

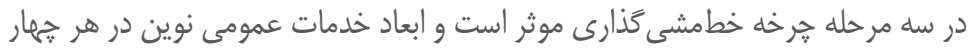

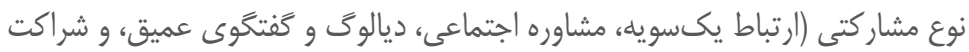

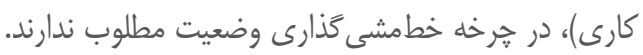

كليدوازهها: خدمات عمو مى نوين، خطمشى كذارى عمومى، فر ايند

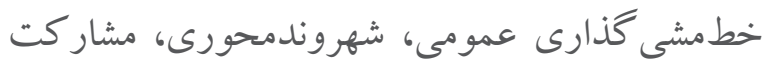

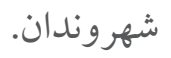

1. دانشجوى دكترى گروه مديريت دولتى، دانشكده مديريت و اقتصاد، واحد علوم تحقيقات، دانشكاه آزاد bozorginejad@tehran.ir

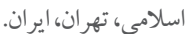
r. دانشيار گروه مديريت دولتى، دانشكده مديريت وانيت و اقتصاد واحد علوم تحقيقات، دانشكاه آزاد اسلامى،

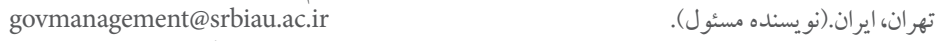
ب. استاد گروه مديريت دولتى، دانشكده مديريت و اقتصاد، واحد علوم تحقيقات، دانشكاه آزاد اسلامى، تهران، A.faghihi@srbiau.ac.ir 


\section{مقام}

سازمان ها همانند حلقههاى ارتباطى بين فرد و جامعه، از اجزاى اصلى بدنه اجتماعى هستند كه به

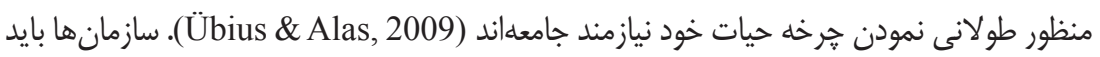

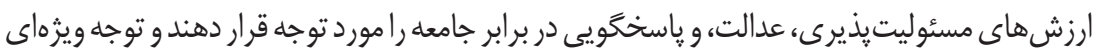

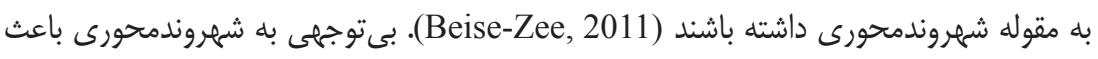
كاهش مشروعيت سيستم و شكست سازمان هاى بخش دولتى در اجتماع مى شود (Taylor, 2006). بىتوجهى و فاصله سازمانهاى بخش دولتى از شهروندمحورى، تمركز صِرف مديران به اهداف

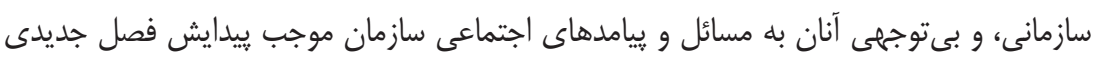

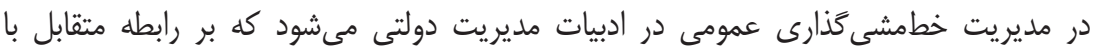

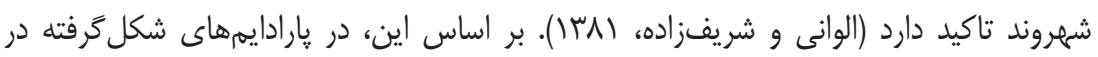
مديريت دولتى، يارادايم خدمات عمومى نوين بر شهروندمحورى تمركز دارد. خدمات عمومى نوين

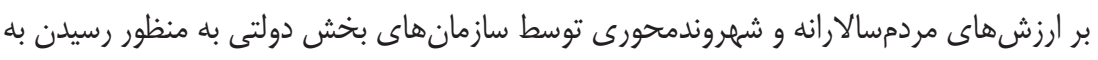

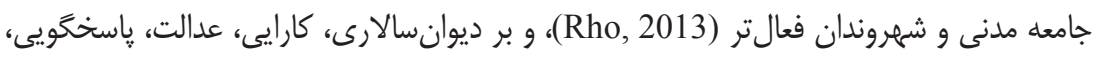
و مسئوليت توجه دارد (Callahan, 2010). بر اساس بازبينى انجامشده، يُوهش هاى بسيار محدودى در موضوع خدمات عمومى نوين

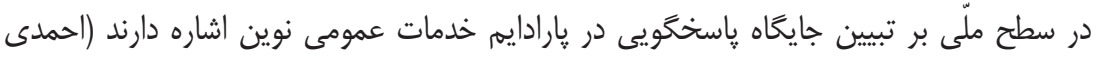

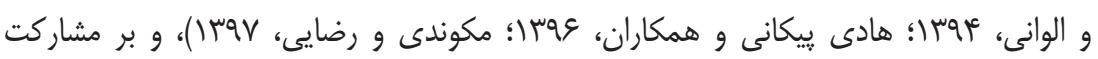
شهروندى متمركز نيستند. علاوه بر آن، در سطح شهردارى (تهران) نيز هيج يزوهشى در حوزئ خدمات عمومى نوين انجام نشده و اين شكافى است كه در ادبيات ايجاد شده است. يعنى ارائه

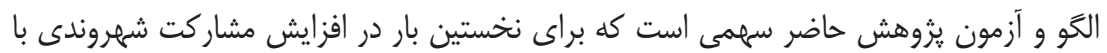
توجه به ابعاد خدمات عمومى نوين در مراحل جرخه خطمشى گذارى مورد بررسى قرار مى گئيرد. در اين مورد، شهردارى تهران به عنوان يك موسسه دولتى، بلدون توجه به مقوله شهروندمحورى، با حالشها و نابهنجارىهاى بسيارى در مديريت شهرى مواجه خواهد بود (عليزاده و همكاران،

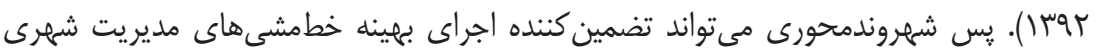
باشد. بر اساس بررسىهاى صورتگرفته، يارادايم خدمات دولتى نوين در شهردارى تهران به 
عنوان يك رويكرد جديد مورد توجه قرار نمى كيرد و در ادبيات مديريت حاكم بر آن به به عنوان

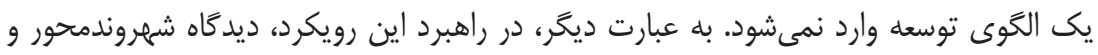

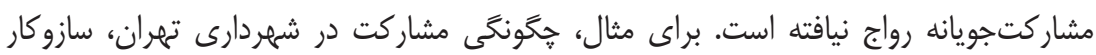
مشار كت، و موضوعهاى مشار كت مشخص نيست نيست

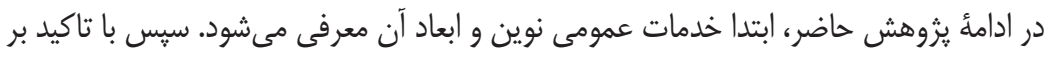

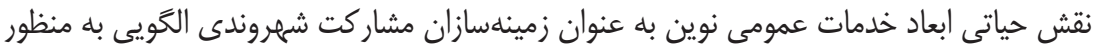

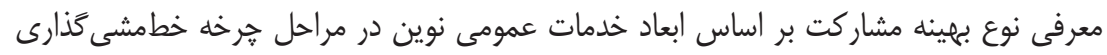

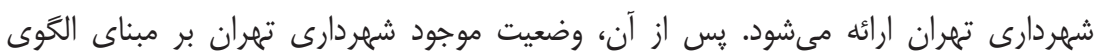

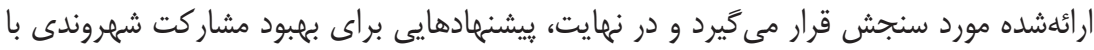

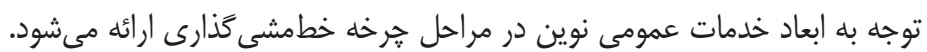

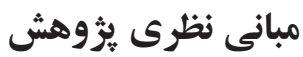

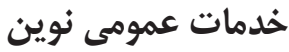
خدمات عمومى در عصر حاضر بلهرعت در حال رشد است و باسخ سريع به مشكلات بيجيحيده

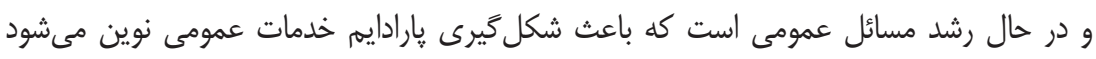

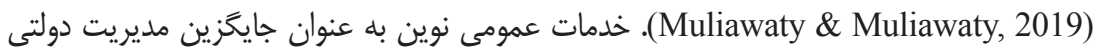

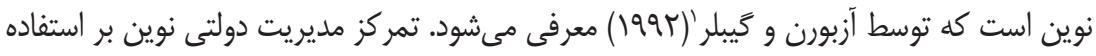

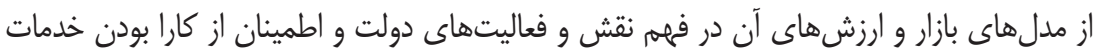

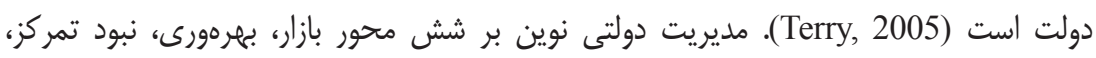

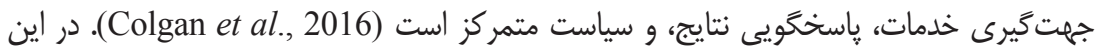

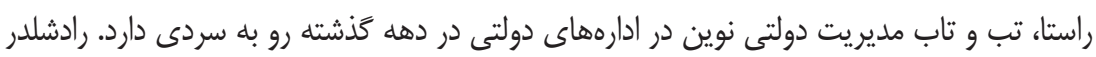

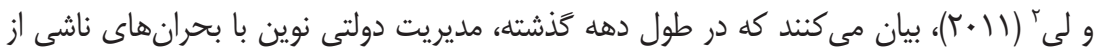

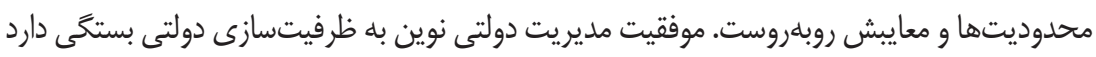

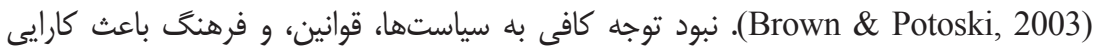

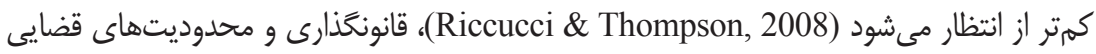

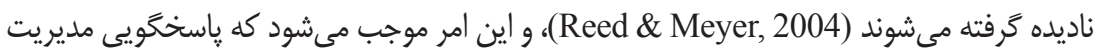

1. Osborne \& Gaebler

2. Raadschelders \& Lee 
دولتى نوين به شهروندان و جامعه مدنى كاهش يابد (Romzek \& Johnston, 2005). در نتيجه،

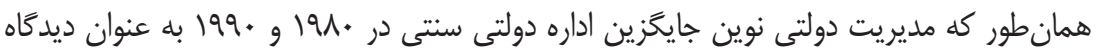

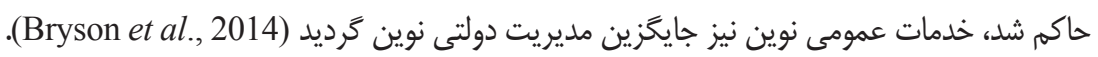

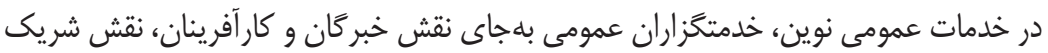
و تسهيل دقيق شناسايى كنند و روابطى مبتنى بر اعتماد با يكديگر ايجاد نمايند. تاكيد اين يارادايم بر ايجاد

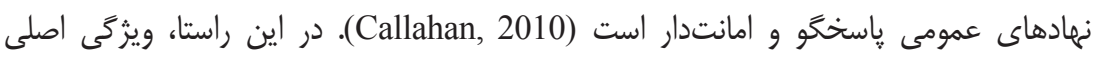

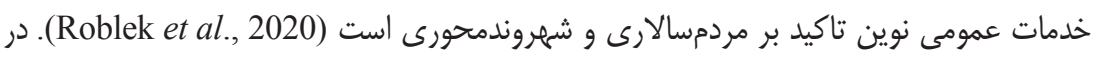

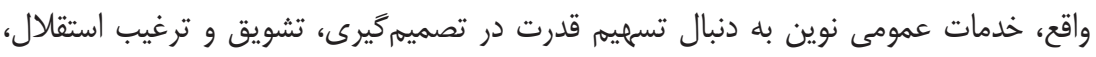

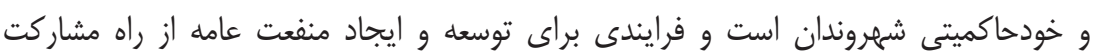

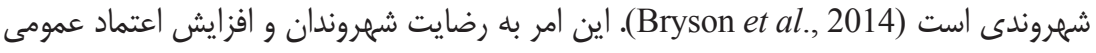
منجر مى شود (Alamsyah, 2019).

\section{ابعاد خدمات عمومى نوين}

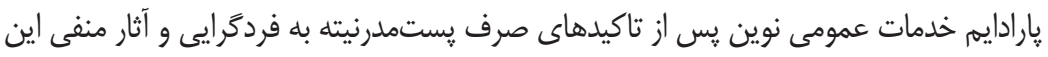

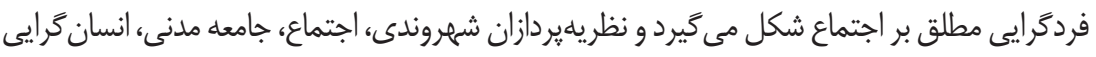

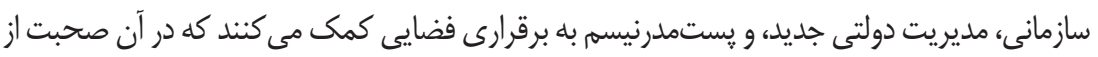

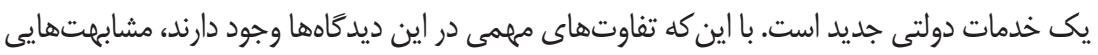

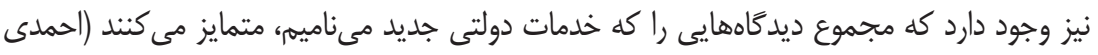

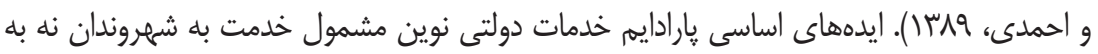

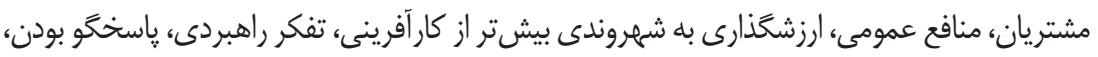

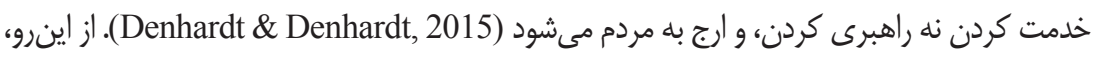

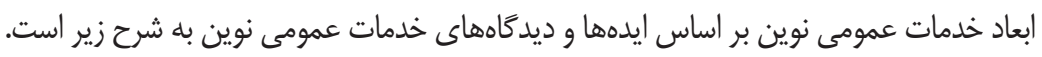

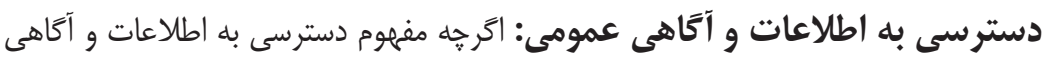

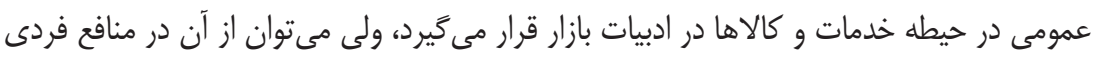

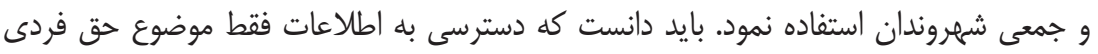
نيست، بلكه يك مسئوليت سياسى است (Denhardt \& Denhardt, 2015). انتخاب و توافقمحورى: جامعه از ذىنفعان كَناكون تشكيل مىشود و ضرورى است كه 
ميان اين ذىنفعان در مواقع تعارض منافع ميانجى گرى شود، كه اين مهم بخشى از مسئوليت دولت

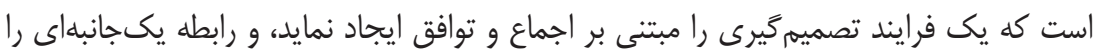

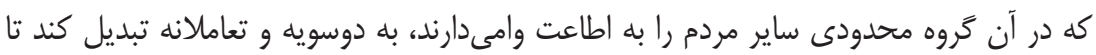
انتخابهاى مطلوب براى همه ذىىنفعان مد نظر قرار كَيرد (اميرزاده و بركيور، لوجسا).

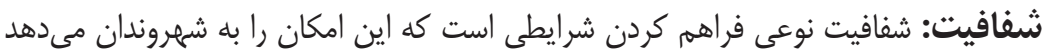
كه در مورد فرايند تصميمَيرى دولت آكاهى يابند. و دولت بايد در تصميمَيرى همانند اجراى قوانين و خطمشىها شفافيت كامل داشته باشد تا تمامى اطلاعات به وسيله رسانهها و مردم بdراحتى دسترسيذير و فهمهيذير باشند (سردارنيا و شاكرى، أوسا).

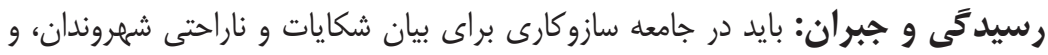

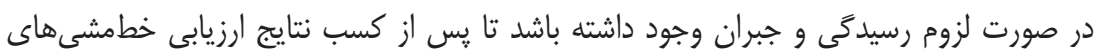
اجرايى، نقاط قوت و ضعف مشخص شود، و به فعال شدن برنامههاى يشتيبانى و در نتيجه، اصلاح خطمشى يا حذف آن منجر شود (دانشفرد، هوس إ). عدالت و انصاف اجتماعى: انصاف و فراگير بودن شامل تضمين حقوق افراد در جهت

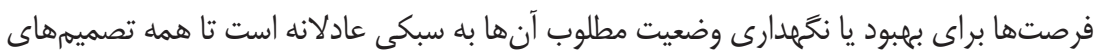
يك سازمان درون :ار يوبى اتخاذ شوند كه آيندهمحور باشند (Hill \& Hupe, 2014).

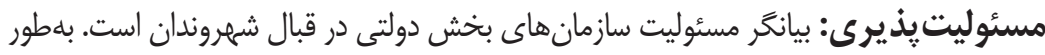

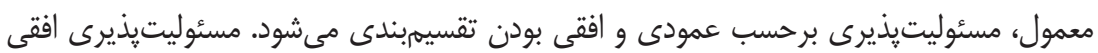

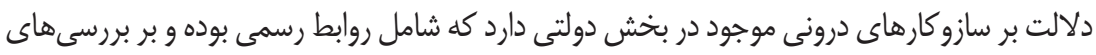
داخلى متمركز است، و مسئوليتيذيرى عمودى يا اجتماعى دولت و شهروندان را با سازوكارهاى داى داري رسمى و باطور شفافتر از راه انتخابات به يكديخر ييوند مى مدهد (Hill \& Hupe, 2014).

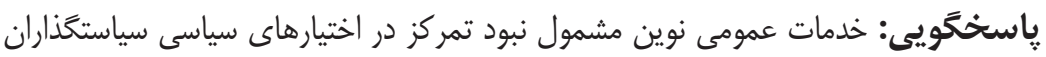

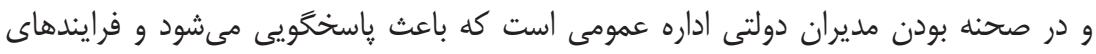

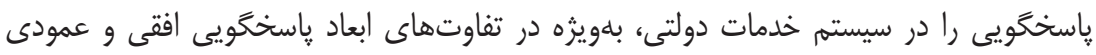

تسهيل مى كند (Bell \& Shelman, 2011). اثربخشى و كارايى: فرايندها و نهادها بايد نتايجى را ارائه دهند كه نياز هاى جامعه را در

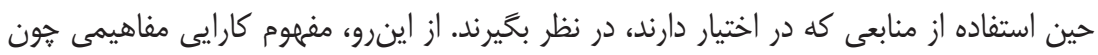

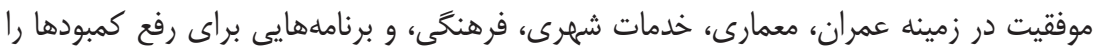

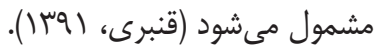


حاكميت قانون: حاكميت قانون، به عنوان اجماع گسترده سياسى است كه يك مسئله

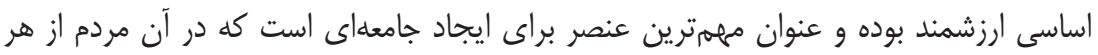
طيف و با هر عقيدهاى بتوانند بدون هيج نوع تبعيضى زندگى كنند. براى اجراى بهتر اين مسئله

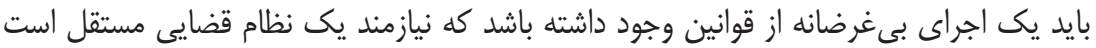

.(Hill \& Hupe, 2014)

بر اساس اين، ابعاد و شاخصهاى خدمات عمومى نوين در مديريت شهرى تهران به تشريح

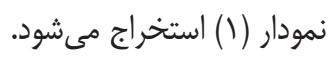

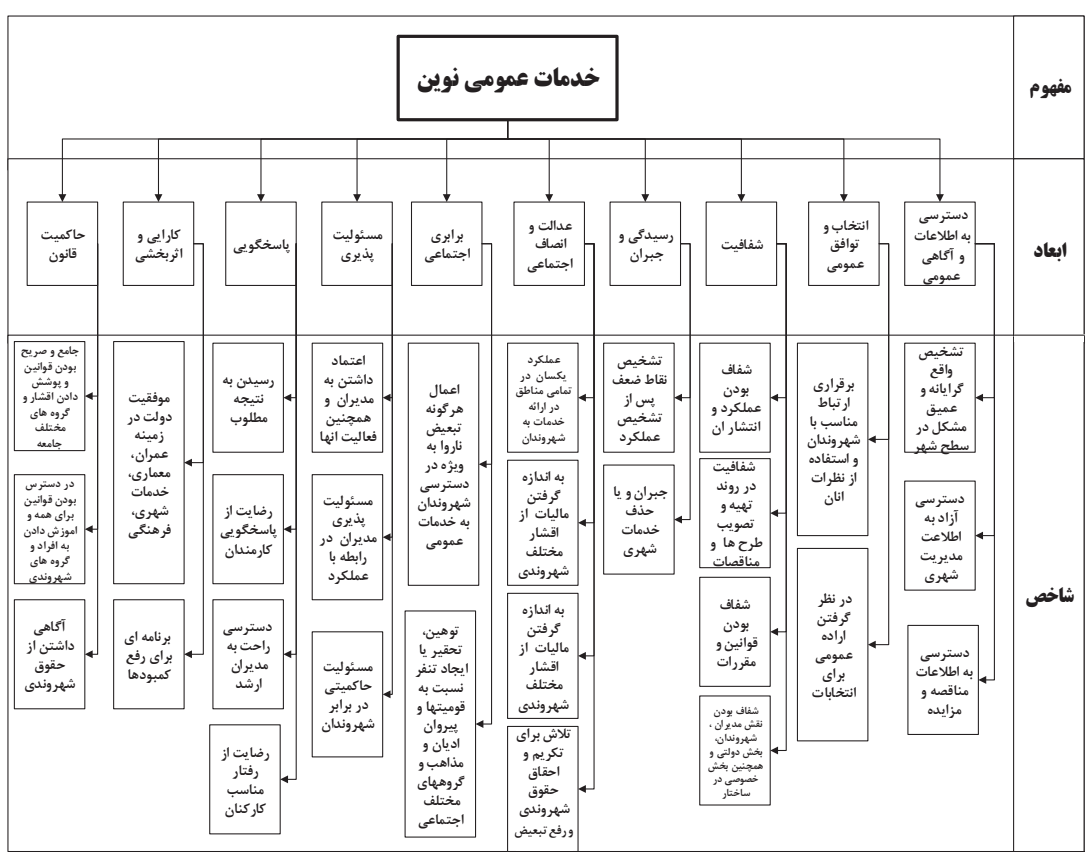

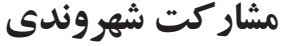

از سال •199 مفهوم مشاركت شهروندى بر اساس קنج يارادايم مديريت دولتى شامل اداره دولتى نوين، مديريت دولتى نوين، ارزشهاى دولتى، خدمات عمومى نوين، و حكمرانى دولتى

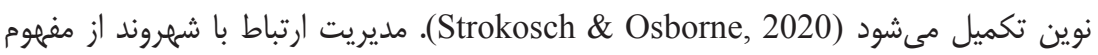


مديريت ارتباط با مشترى در بخش خصوصى و مديريت دولتى نوين نشأت مى گيرد. اين مفهوم

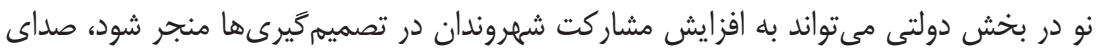

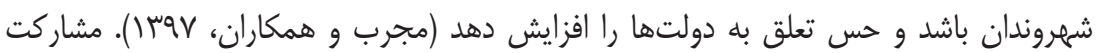
شهروندى، مشاركت تعدادى از عموم مردم در دستور كارگذارى، تصميمَّي، و فعاليتهاى لهاى

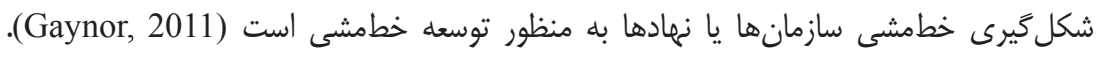

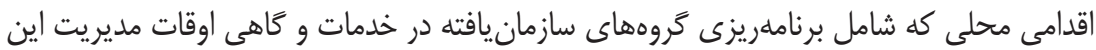
خدمات است (Holmes, 2010). فرايندى است كه به وسيله آن توجهها، نيازها، و ارزشهاى مردمى در تصميمَيرى شركتى و دولتى مشاركت داده مى شود (Davis, 2010). همجنين، به عنوان فرايند انتخاب ارزش است، بلطورى كه مردم حق دارند رهبران خود را انتخاب كنند و به

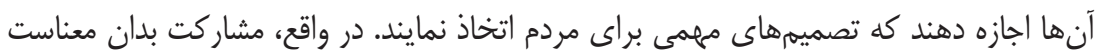

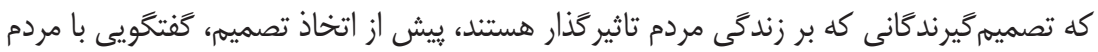

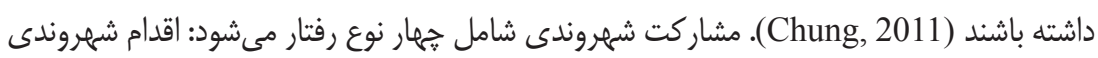
از قبيل اعتراضها، سخنرانى، و تبليغات دركير ساختن شهروندى از قبيل دادرسى، استماع، و

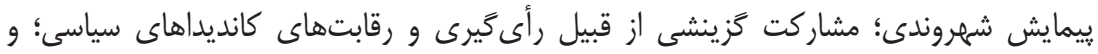

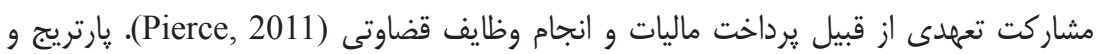

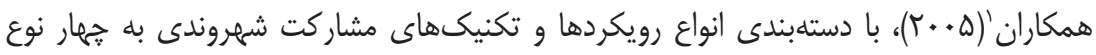

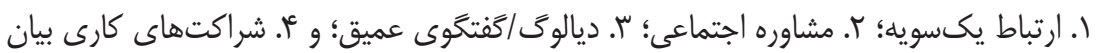

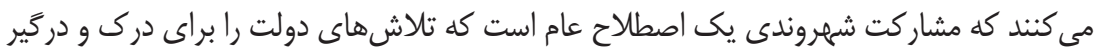

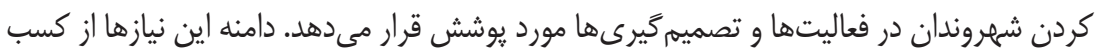

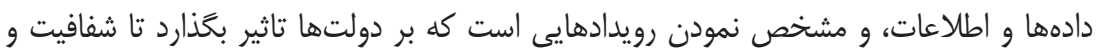

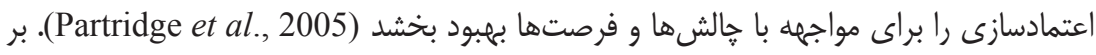

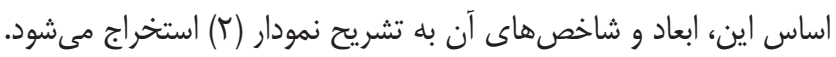

1. Partridge et al. 


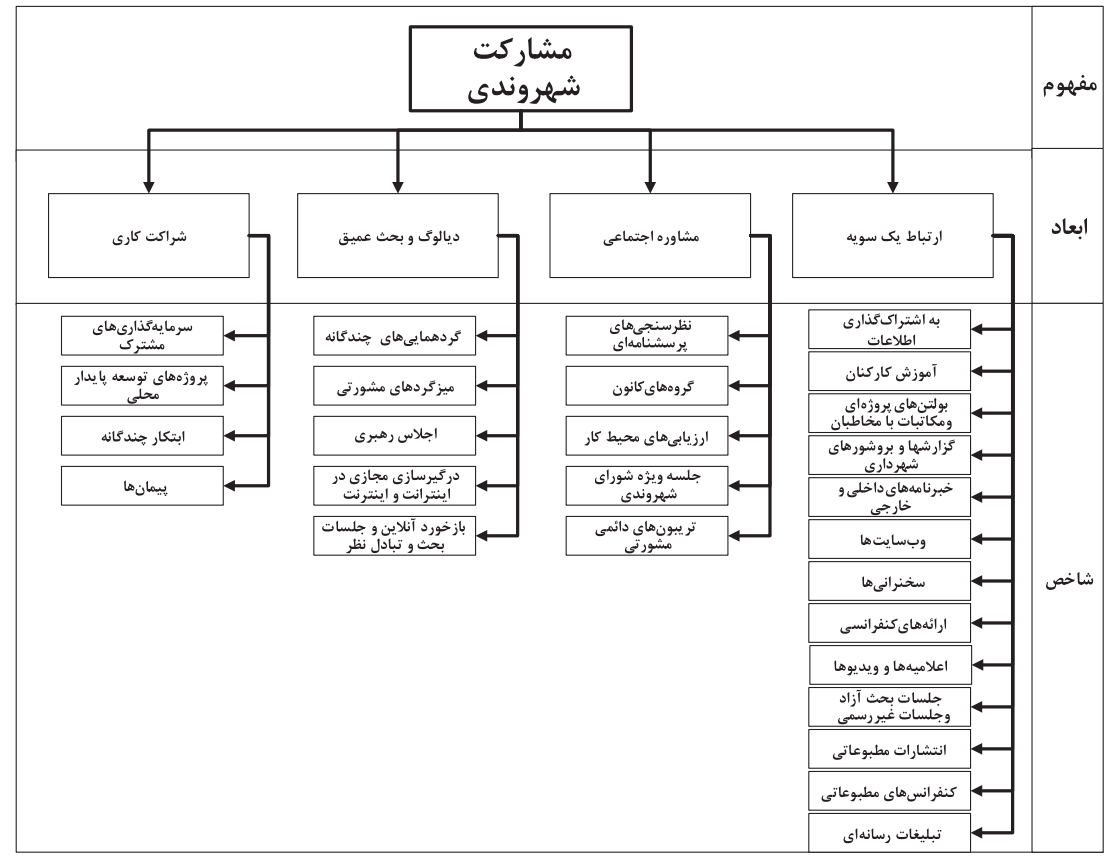

201

نمودار rا: ابعاد و شاخصهاى مشار كت شهروندى

\section{فراينل خطمشى خذارى}

اگر يارادايم خدمات عمومى نوين خوب فهميده شود، سبب مىشود كه مديران به دنبال تعادل درستى بين دسترسى شهروندان و مشاركت آنها در فرايند خطمشى گذارى باشند. بر اساس اين، اداره امور عمومى مستلزم خطمشى گذارى در زمينههاى متفاوت و متنوع فرهنگىى، اجتماعى، б سياسى، و اقتصادى است. شبكههاى خطمشى شامل بازيخران دولتى و اجتماعى هستند كه تعامل آنان با يكديگر به شكل گيرى يا اجراى خطمشى منجر مىشود (رهنورد و همكاران، عهسا). خطمشى كذارى عمومى فرايندى را شكل مى دهد كه شامل جندين فعاليت و مرحله است. بلهور كلى، فرايند خطمشى گذارى عمومى شامل مراحل شناخت، درك و بيان مسئله يا مشكل؛ ارجاع و طرح مسئله در سازمانها و موسسههاى عمومى تهيه و تدوين خطمشى عمومى؛ قانونى كردن و مشروعيت بخشيدن به خطمشى عمومى؛ و ابلاغ، اجرا، و ارزشيابى خطمشى عمومى مى (الوانى و شريفزاده، اريا). فرايند خطمشى گذارى را مىتوان مشمول اين مراحل دانست: .

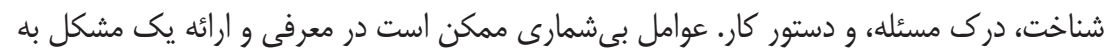


عنوان مشكل عمومى نقش داشته باشند. از ميان اين عوامل مى توان به تاثير مطالعات، سخنرانىها،

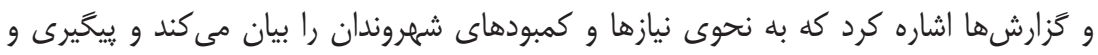

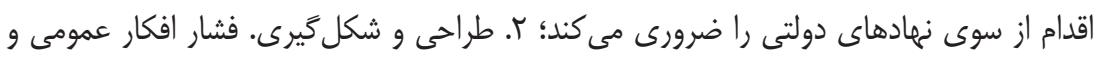

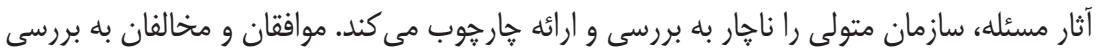

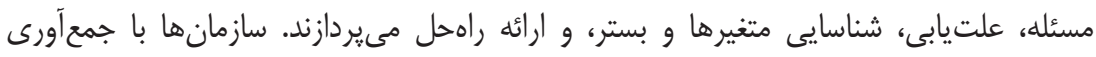

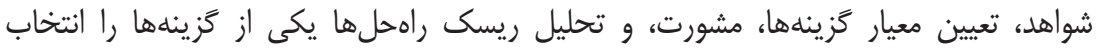

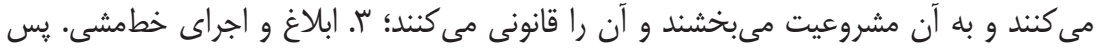
از مجاز شدن اجراى خطمشى، مراجع اجراى آن را به واحدهاى سازمانى ابلاغ مى كنند. در اجراى

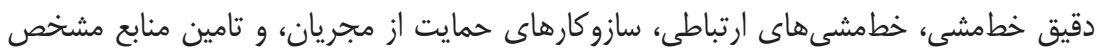

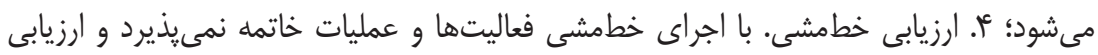

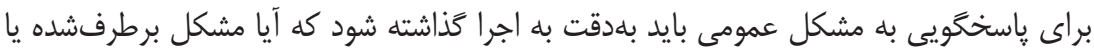

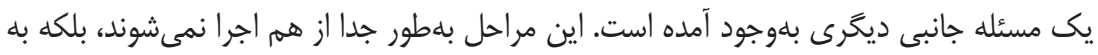

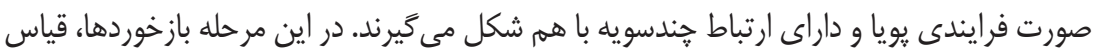

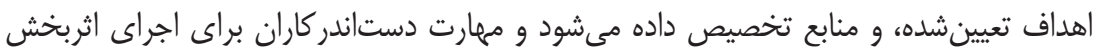

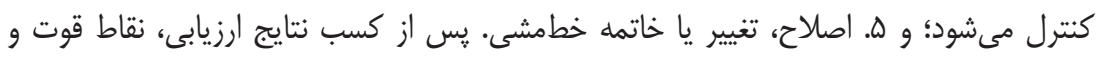

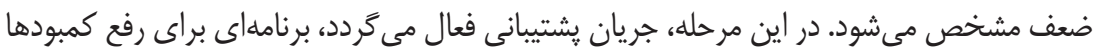

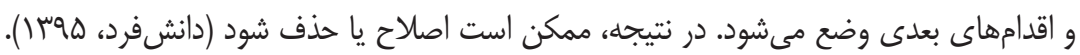
خطمشىهاى عمومى نقش مهمى در رهاوردهاى اجتماعى و توسعه كشورها ايفا مى كنند.

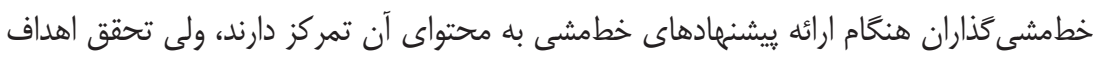

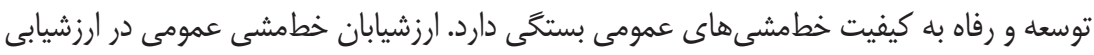

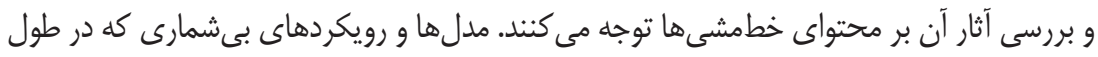

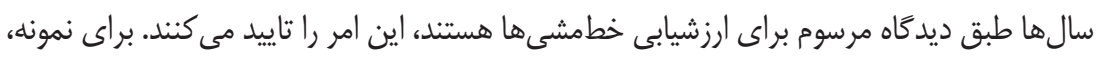

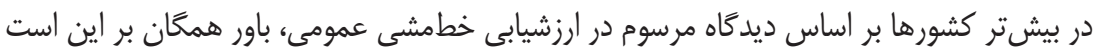

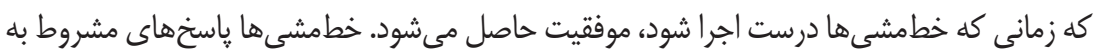
مسائل عمومى هستند. خطمشى كه در يك مكان و زمان خاصى درست انجام شود، ممكن است در دراف

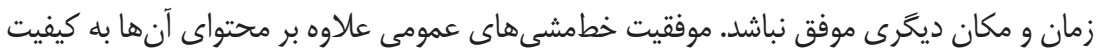

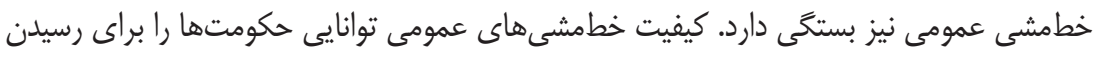

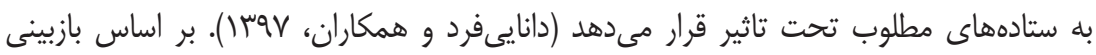


ادبيات، ماتريسى تشكيل مىشود كه در محور X آن فرايندهاى خطمشى گذارى شامل شناسايى

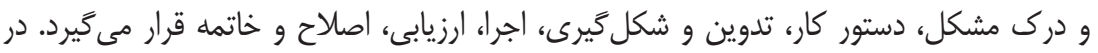

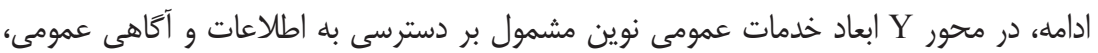

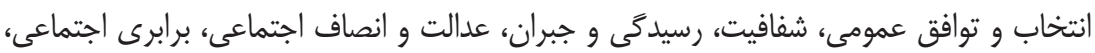

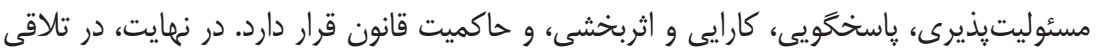

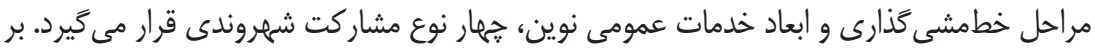

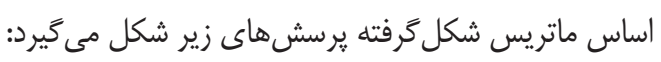

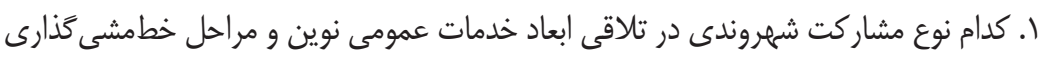

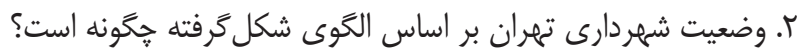
اولويت دارد؟ $\sum^{2}$

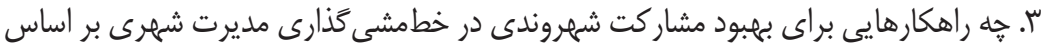

ابعاد خدمات عمومى نوين وجود دارد؟

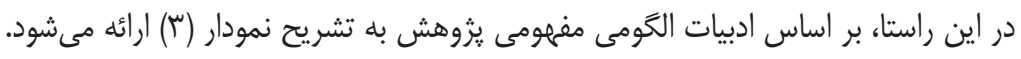

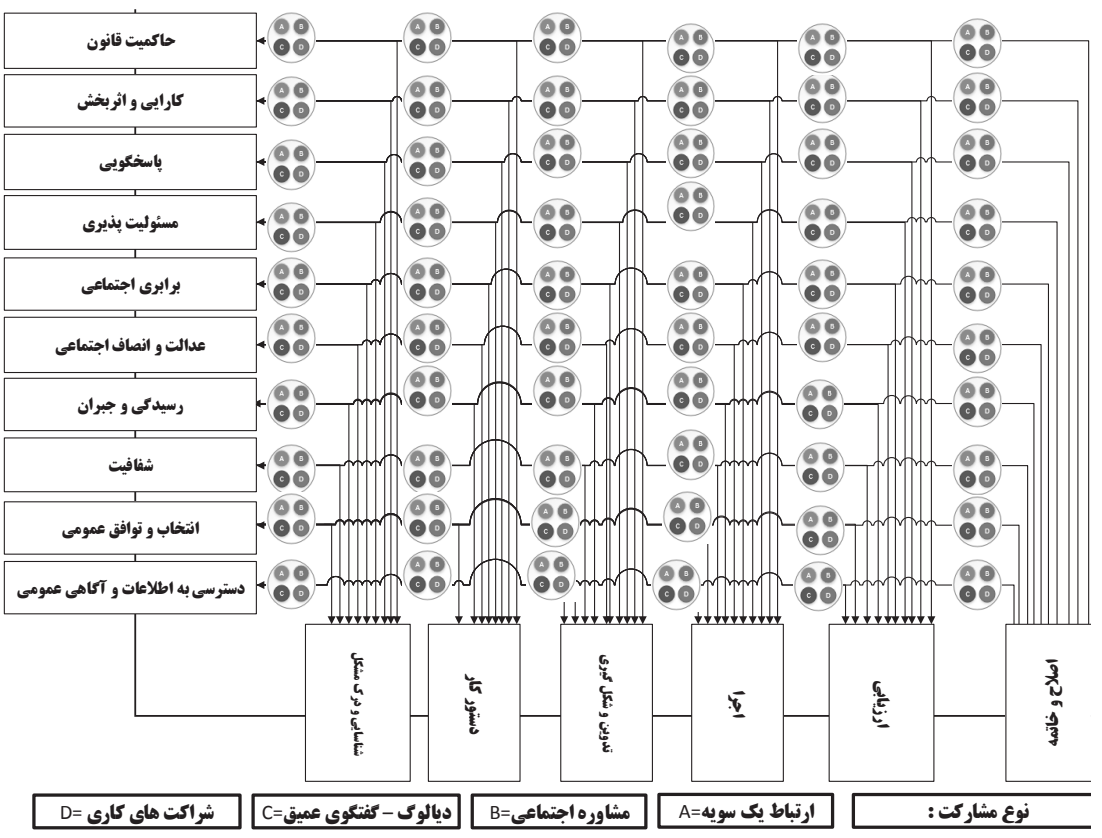




\section{روششناسى ثزوهش}

يثوهش حاضر از لحاظ هدف توصيفى-ييمايشى است، به اين دليل كه قصد داشتيم تصويرى مشروح از وضعيت مشاركت شهروندى بر اساس ابعاد خدمات عمومى نوين در خطمشى كذارى شهردارى مشخص

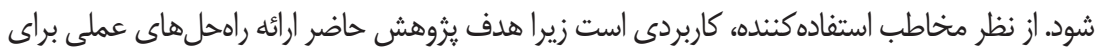

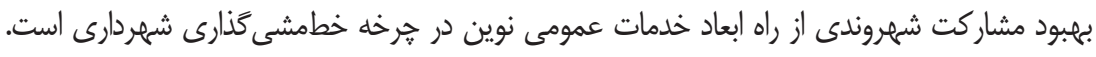

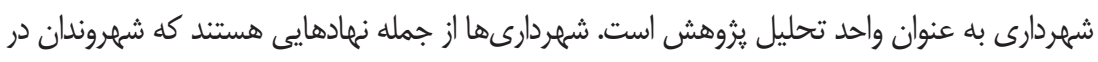

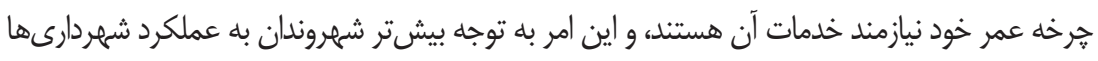

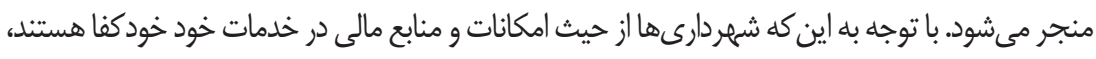

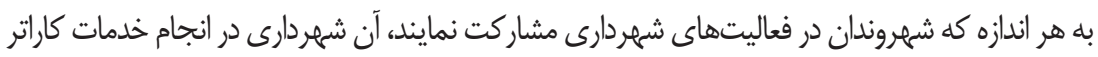

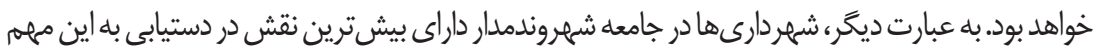

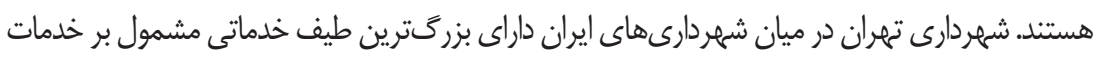

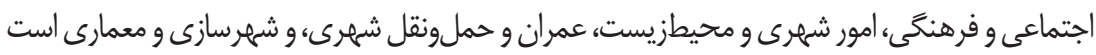

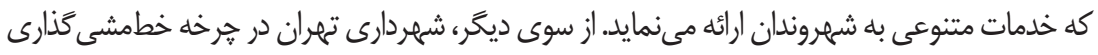

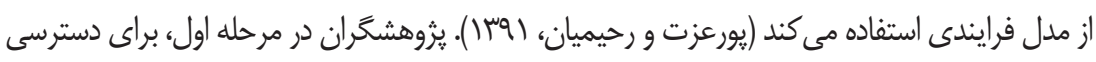

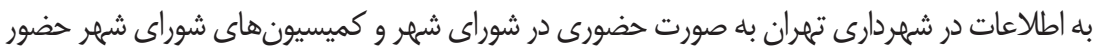

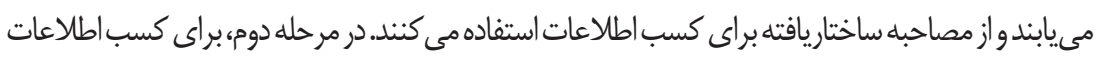

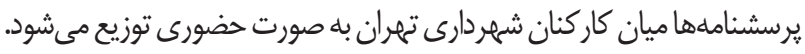

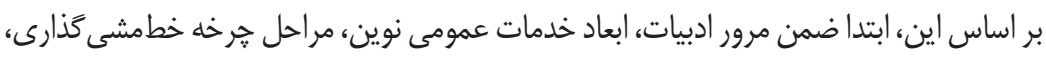

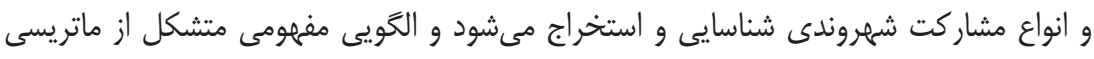

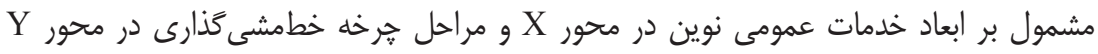

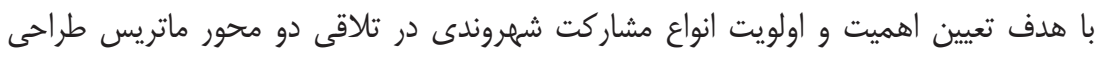

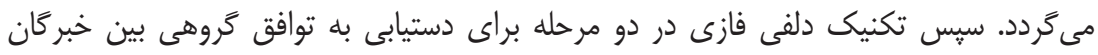

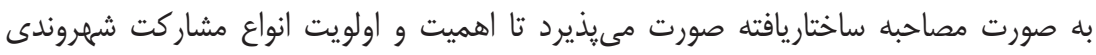

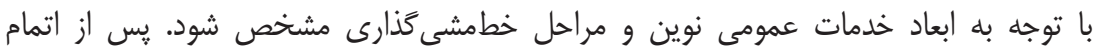

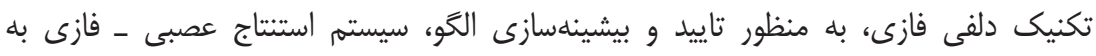

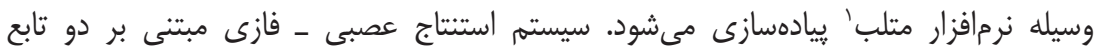

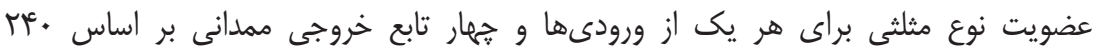

1. Matlab R2018b 
قانون' طراحى مىشود كه به روش تركيبى آموزش مىيبنند. در نهايت، بِ از نهايى شدن الكو

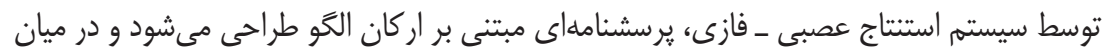

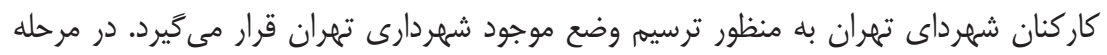
نخست، مشمول خبر كان مديريت شهرى است كه به منظور انتخاب آنان، شرايط احرازى به تشريح

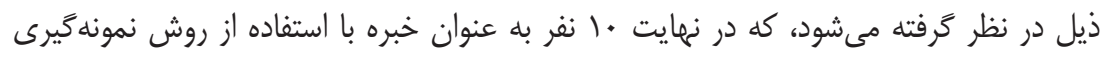
هدفمند يا قضاوتى شناسايى و انتخاب مى شوند: • دست كم يك دوره به عنوان عضو شوراى شهر اسلامى شهر تهران حضور داشتهاند.

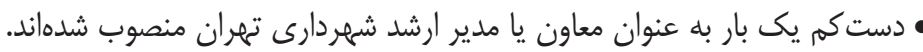

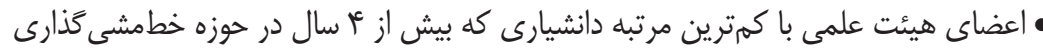

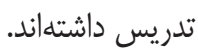
كارشناسان و مديران سازمان شهردارى تهران كه دستكم. •ا سال سابقه خدمت در سازمان مربوطه داشتهاند.

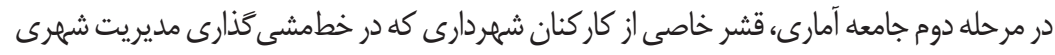

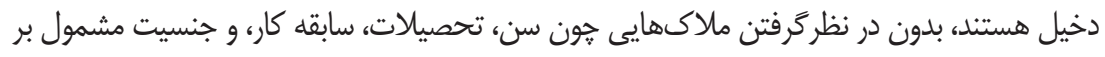

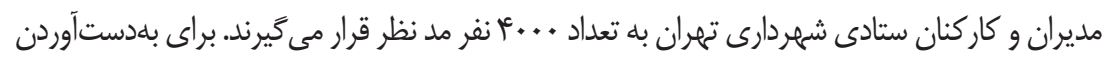

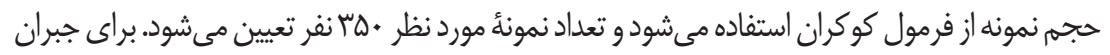

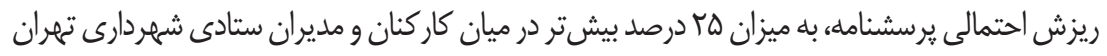

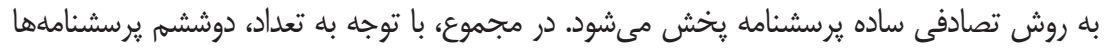

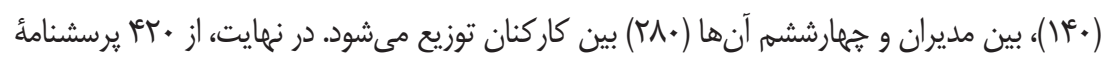

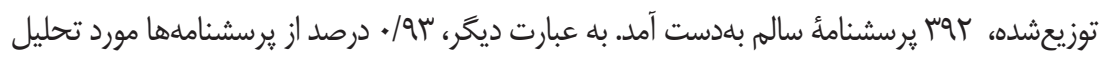

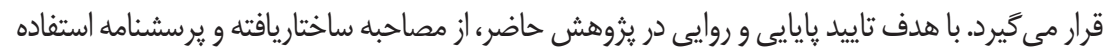

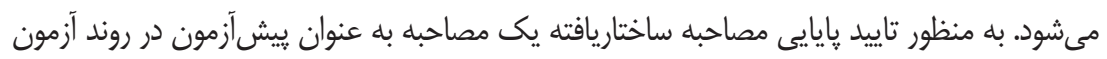

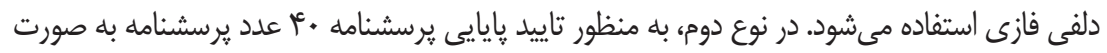

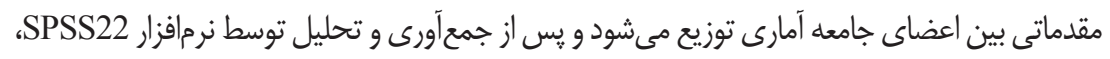

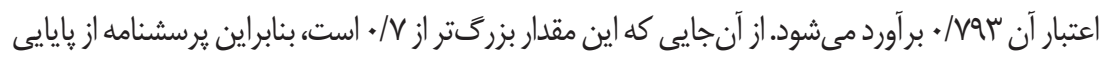

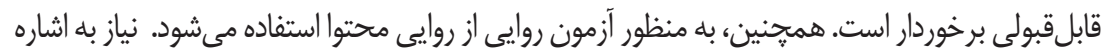
است كه تمامى يرسشها از توزيع نرمال ييروى مئ كنند.

1. Rule 


\section{تجزيلووتحليل يافته ها}

روش دلفى فازى

در يزوهش حاضر، از اعداد فازى (عدد فازى مثلثى)، براى فازىسازى نظرهاى خبر كان (.1.

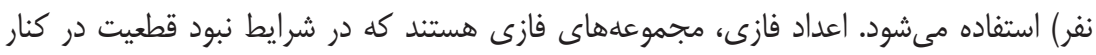

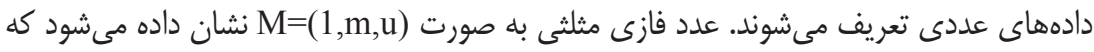
تابع عضويت آن به تشريح فرمول (() است:

$U_{M}(x)=\left\{\begin{array}{cl}\frac{x-1}{m-1} & l \leq x \leq m \\ \frac{u-x}{u-m} & m \leq x \leq u \\ 0 & \text { otherwise }\end{array}\right.$

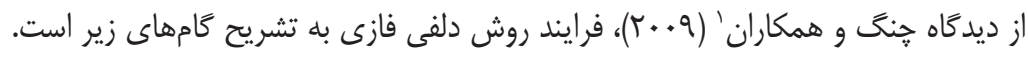

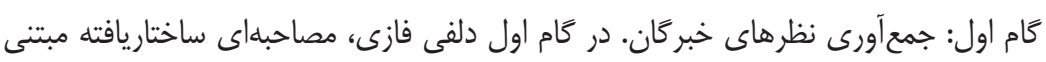

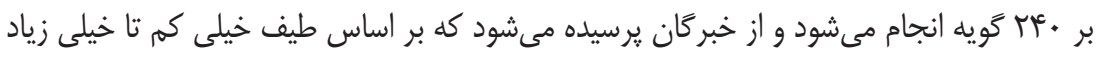

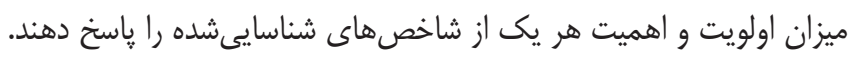

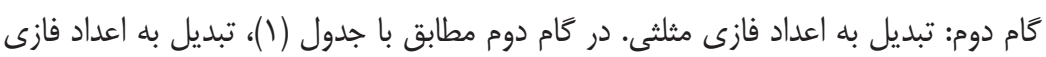
مثلثى صورت مى ميذيرد.

\section{جدول 1: اعداد فازى مثلثى متناظر با متغيرهاى كلامى}

\begin{tabular}{|c|c|}
\hline عدد فازى مثلثى (1, m, u) & متغير هاى كلامى \\
\hline$(\cdot / v Q, 1,1)$ & خيلى زياد \\
\hline$\left(\cdot / \Delta_{6} \cdot / V Q_{0}, 1\right)$ & زياد \\
\hline$\left(\cdot / T \Delta_{6} \cdot / \Delta_{6} \cdot / V \Delta\right)$ & متوسط \\
\hline$\left(\cdot, \cdot / \Gamma \Delta_{6} \cdot / \Delta\right)$ & كم \\
\hline$(\cdot \sqrt{ } \cdot ، \cdot / \Delta)$ & خيلى كم \\
\hline
\end{tabular}

به اين ترتيب اعداد فازى مثلثى به نظر هر يك از خبركان ارائه مى شود و مجموعه اعداد فازى في إنى مثلثى با استفاده از فرمول (r) بهدست مى آيد. $\tilde{A}^{(i)}=\left(a_{1}^{(i)}, a_{2}^{(i)}, a_{3}^{(i)}\right) \quad i=1,2,3 \ldots . \mathrm{n}$

كام سوم: ميانكَين مجموعهها بر اساس فرمول (َّ) محاسبه مىشود.

$\tilde{A}_{m}=\left(a_{m 1}, a_{m 2}, a_{m 3}\right)=\left(\frac{1}{n} \sum_{i=1}^{n} a_{1}^{i}, \frac{1}{n} \sum_{i=1}^{n} a_{2}^{i}, \frac{1}{n} \sum_{i=1}^{n} a_{3}^{i}\right)$ 
جدول ب: ديد Fاه خبر كان در خصوص خدمات عمومى نوين در جرخه خطمشى كذارى بر اساس

ارتباط يككسويه ـ مرحله اول

\begin{tabular}{|c|c|c|c|c|}
\hline $\mathrm{S}_{1}$ & $(1, \mathrm{~m}, \mathrm{u})$ & شاخص & مولفه & بعد \\
\hline$\cdot / \mathrm{V}$ & $(\cdot / 09, \cdot / 11 ، \cdot / 94)$ & 1 & دسترسى به اطلاعات عمومى & \multirow{10}{*}{ اجرا } \\
\hline$\cdot / 4 y$ & $(\cdot / 4 \uparrow, \cdot / 4 \Delta, \cdot / 4 q)$ & r & توافت عمومى & \\
\hline$\cdot / M$ & $(\cdot 199 ، \cdot 199, \cdot 191)$ & 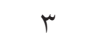 & شفافيت & \\
\hline$\cdot / \mu$ & $(\cdot / \cdot ، / T / T V)$ & r & | & \\
\hline .199 & $(\cdot / 40, \cdot / 99, \cdot / 14)$ & $\Delta$ & انصا & \\
\hline$\cdot 19 \mathrm{~V}$ & $(\cdot / 49 ، \cdot 199 ، \cdot 119)$ & 9 & 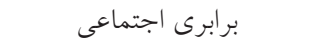 & \\
\hline 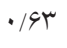 & $\left(\cdot / 4 \cdot \sigma \cdot / 9 V_{6} \cdot / \Lambda 4\right)$ & V & ت ت بذيرى & \\
\hline .199 & $(\cdot / 40, \cdot / 99 \cdot \cdot / 14)$ & $\wedge$ & 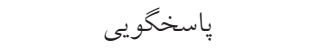 & \\
\hline$\cdot 191$ & $(\cdot / r \Lambda \cdot \cdot / 90, \cdot / \Lambda T)$ & 9 & 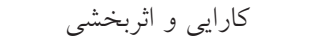 & \\
\hline$\cdot / \Lambda K^{4}$ & $(\cdot / 9 \mu \cdot \cdot / M \cdot 1)$ & $1 \cdot$ & 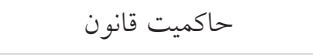 & \\
\hline$\cdot / 9$ & $(\cdot / \mathrm{V} \cdot \cdot / 9 \wedge, \cdot / 1)$ & 1 & دسترسى به اطلاعات عمو مى & \multirow{10}{*}{ ارزيابى } \\
\hline •/Or & $\left(\cdot / \Delta T_{6} \cdot / \Delta V\right.$ ، $\left.\cdot / \Delta T\right)$ & r & 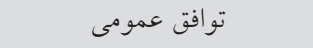 & \\
\hline$\cdot / 91$ & $(\cdot / v 0, \cdot / 99, \cdot / 1)$ & r & 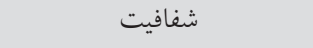 & \\
\hline 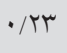 & $(\cdot / r, \cdot / r \Delta \cdot$ • • $/ r q)$ & r & | - مسيد & \\
\hline$\cdot / 09$ & $(\cdot / \Delta 9, \cdot / \Delta \Delta, \cdot / \Delta \psi)$ & $\Delta$ & انصا & \\
\hline$\cdot / \Delta \Delta$ & $\left(\cdot / \Delta \Lambda ، \cdot / \Delta \psi_{6} \cdot / \Delta \mu^{\prime}\right)$ & 4 & 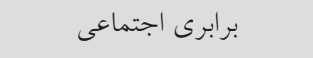 & \\
\hline$\cdot / \mathrm{Vq}$ & $\left(\cdot / 09 \cdot \cdot / \wedge r^{*} \cdot / 90\right)$ & V & 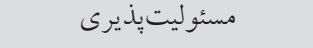 & \\
\hline$\cdot / / 9$ & $(\cdot / 09 ، \cdot / \wedge 4, \cdot / 90)$ & $\wedge$ & 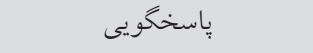 & \\
\hline . 194 & $\left(\cdot / 4 \cdot \sigma \cdot / 9 V_{6} \cdot / \Lambda 4\right)$ & 9 & اثربخشى & \\
\hline$\cdot / \wedge \varphi$ & $\left(\cdot / 9 V_{6} \cdot / 9 r_{6} \cdot / 91\right)$ & 1. & حاكميت قانون & \\
\hline$\cdot / N$ & $\left(\cdot / \Delta T_{6} \cdot / V V ، \cdot / 91\right)$ & 1 & دسترسى به اطلاعات عمومى & \multirow{10}{*}{ خاتمه } \\
\hline • & $\left(\bullet / Y D_{6} \cdot / T 1 \cdot \cdot / T r\right)$ & r & 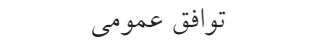 & \\
\hline$\cdot / \mathrm{V}$ & $(\cdot / 09 ، \cdot / 11 ، \cdot / 94)$ & r & شفافيت & \\
\hline$\cdot / \wedge 9$ & $\left(\cdot / 9 V_{6} \cdot / 9 r_{6} \cdot / 91\right)$ & r & رسيدگى و جبران & \\
\hline$\cdot / 4 t$ & $(\cdot / r T \cdot \cdot / r \Delta \cdot$ • $/ / T q)$ & $\Delta$ & انصاف اجتماعى & \\
\hline$\cdot / T+4$ & $\left(\cdot / r r_{6} \cdot / r \omega_{6} \cdot / r q\right)$ & 4 & ل ع اجتماعى & \\
\hline$\cdot / V T$ & $\left(\cdot / \uparrow \wedge, \cdot / \mu^{\top}, \cdot / q \uparrow\right)$ & V & مسئوليت پيذيرى & \\
\hline$\cdot / V 9$ & $\left(\cdot / \Delta q^{q} \cdot \cdot / v q ، \cdot / q 4\right)$ & $\wedge$ & 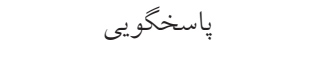 & \\
\hline$\cdot /$ Kt & $(\cdot / \mathbb{\leftarrow}, \cdot / \mathbb{*} \Delta, \cdot / \mathbb{*} \cdot)$ & 9 & كارايى و اثربخشى & \\
\hline$\cdot / \mu k$ & $\left(\cdot / \mu \Lambda_{6} \cdot / r \Delta \cdot \cdot / r q\right)$ & $1 \cdot$ & حاكميت قانون & \\
\hline
\end{tabular}

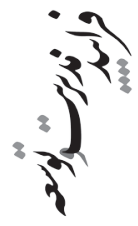


ادامه جدول r: ديد كاه خبر كان در خصوص خدمات عمومى نوين در جرخه خطمشى تذارى بر اساس ارتباط يككسويه ــ مرحله اول عمومي نوين

\begin{tabular}{|c|c|c|c|c|}
\hline $\mathrm{s}_{1}$ & $(1, \mathrm{~m}, \mathrm{u})$ & شاخص & مولفه & بعد \\
\hline$\cdot / 14$ & $\left(\cdot / 9 V_{6} \cdot / 9 r_{6} \cdot / 9 \Lambda\right)$ & 1 & دسترسى به اطلاعات عمومى & \multirow{10}{*}{ درى مشكل } \\
\hline 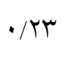 & $\left(\cdot / r \Delta \cdot \cdot / r I_{6} \cdot / r(r)\right.$ & r & توافق عمومى & \\
\hline$\cdot \pi \Delta$ & $(\cdot / \mu ، \cdot / \mu, \cdot / \mu \cdot)$ & r & شفافيت & \\
\hline$\cdot / T V$ & $(\cdot / 19 ، \cdot / r V ، \cdot / r 4)$ & r & رسيدگى و جبران & \\
\hline$\cdot / \Delta r$ & $(\cdot / 01 ، \cdot / 00, \cdot / 0 \cdot)$ & 0 & انصاف اجتماعى & \\
\hline$\cdot / 09$ & $(\cdot / \Delta Q ، \cdot / \Delta D, \cdot / \Delta Y)$ & 4 & برابرى اجتماعى & \\
\hline$\cdot / 09$ & $(\cdot / \Delta Q, \cdot / \Delta D, \cdot / \Delta Y)$ & v & مسئوليت يِيرى & \\
\hline$\cdot / r q$ & $(\cdot / r 1 \cdot \cdot / r V ، \cdot / r q)$ & $\wedge$ & ياسخگُويى & \\
\hline • & $(\cdot / r \Delta \cdot$ • $(r) \cdot(r /)$ & 9 & كارايى و اثربخشى & \\
\hline$\cdot / \Lambda r$ & $(\cdot / 9 \pi, ، / 1 \Lambda, 1)$ & 1. & حاكميت قانون & \\
\hline$\cdot / 1 \wedge$ & $(\cdot / r \cdot \ldots / 19, \cdot / 1 \Lambda)$ & 1 & دسترسى به اطلاعات عمومى & \multirow{10}{*}{ دستور كار } \\
\hline$\cdot \pi \wedge$ & $(\cdot / 01, \cdot / 40, \cdot / 0 \cdot)$ & r & توافق عمومى & \\
\hline$\cdot / 91$ & $(\cdot / \vee \Delta, \cdot / 99, \cdot / 1)$ & r & شفافيت & \\
\hline$\cdot / 49$ & $(\cdot / r \Lambda ، \cdot / r \cdot ، \cdot / r)$ & r & رسيدگى و جبران & \\
\hline$\cdot / 0 r$ & $(\cdot / 01 ، \cdot / \Delta 0, \cdot / 0 \cdot)$ & 0 & انصاف اجتماعى & \\
\hline$\cdot / \Delta r$ & $\left(\cdot / 0 r_{6} \cdot / 09, \cdot / 01\right)$ & 4 & برابرى اجتماعى & \\
\hline$\cdot / 19$ & $\left(\cdot / 9 V ، \cdot / 9 r_{6} \cdot / 9 \Lambda\right)$ & v & مسئوليت بذيرى & \\
\hline$\cdot / N 9$ & $(\cdot / 09 ، \cdot / \wedge \&, ، / 90)$ & $\wedge$ & 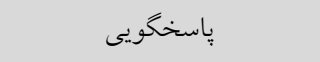 & \\
\hline$\cdot M t$ & $\left(\cdot / \mu \kappa_{0} \cdot / \mu \Delta, \cdot / \kappa \cdot\right)$ & 9 & كارايى و اثربخشى & \\
\hline$\cdot \pi r$ & $(\cdot / r \wedge, \cdot / r \Delta \cdot \cdot / r q)$ & 1. & حاكميت قانون & \\
\hline •/A & $(\cdot / 9 r ، \cdot / M \Lambda ، \cdot / 99)$ & 1 & دسترسى به اطلاعات عمومى & \multirow{10}{*}{ شكل ثليرى و و } \\
\hline$\cdot / D Y$ & $(\cdot / \Delta r ، \cdot / \Delta \Delta, \cdot / \Delta r)$ & r & توافق عمومى & \\
\hline$\cdot 1 \wedge 9$ & $(\cdot / \cdot 9 V / 9 Y . \cdot / 9 \Lambda)$ & r & شفافيت & \\
\hline 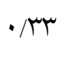 & $(\cdot / r V ، \cdot / \mu Y \cdot(\cdot / \Lambda)$ & r & رسيدگى و جبران & \\
\hline$\cdot / 09$ & $(\cdot / \Delta Q ، \cdot / \Delta \Delta, \cdot / \Delta Y)$ & 0 & انصاف اجتماعى & \\
\hline$\cdot / \Delta \wedge$ & $(\cdot / 91 ، \cdot / 01 ، \cdot 109)$ & 9 & برابرى اجتماعى & \\
\hline$\cdot / \Delta r$ & $(\cdot / \Delta), \cdot / \Delta 0, \cdot / \Delta \cdot)$ & v & مسئوليت يذيرى & \\
\hline$\cdot 19 \Lambda$ & $(\cdot / \uparrow \Delta, ، / v \cdot, \cdot / \wedge q)$ & $\wedge$ & ياسخگويى & \\
\hline$\cdot \pi r$ & $(\cdot / \mu \wedge, \cdot / \mu \Delta \cdot \cdot / r q)$ & 9 & كارايى و اثربخشى & \\
\hline$\cdot / N 9$ & $(\cdot / 09 ، \cdot / 14 ، \cdot / 90)$ & 1. & حاكميت قانون & \\
\hline
\end{tabular}


جدول "ّ: ديد كاه خبر كان در خصوص خدمات عمومى نوين در جرخه خطمشى كذارى بر اساس مشاوره اجتماعى ـ مر حله اول

\begin{tabular}{|c|c|c|c|c|}
\hline $\mathrm{s}_{1}$ & $(1, \mathrm{~m}, \mathrm{u})$ & شاخ & مولفه & بعد \\
\hline$\cdot / \mathrm{M}$ & $(\cdot / 99 ، \cdot / 99 ، \cdot / 91)$ & 1 & دسترسى به اطلاعات عمومى & \multirow{10}{*}{ شرك مشاسايى و } \\
\hline$\cdot / N$ & $\left(\cdot / 0 r_{6} \cdot / V V ، \cdot / 91\right)$ & r & توافق عمومى & \\
\hline$\cdot / \pi 9$ & $(\cdot / \mu 1, \cdot / r V ، \cdot / r q)$ & r & 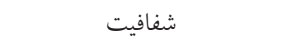 & \\
\hline 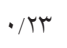 & $(\cdot / r Q \cdot \cdot / r) ، \cdot / r)$ & r & رسيدگى و جبران & \\
\hline$\cdot / T V$ & $(\cdot / r \Lambda \cdot \cdot / r \cdot a \cdot r r)$ & 0 & انصاف اجتماعى & \\
\hline$\cdot / T V$ & $(\cdot / r \Lambda \cdot \cdot / r \cdot \sigma \cdot / r r)$ & 4 & برابرى اجتماعى & \\
\hline$\cdot / \mathrm{VV}$ & $(\cdot / 09 ، \cdot / \Lambda 1 ، \cdot / q 4)$ & v & مسئوليت بذيرى & \\
\hline$\cdot / T V$ & $(\cdot / 19 \cdot * / T V ، \cdot / 44)$ & $\wedge$ & 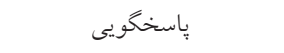 & \\
\hline 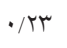 & $(\cdot / r Q \cdot \cdot / r) ، \cdot / T)$ & 9 & كارايى و اثربخشى & \\
\hline . / Q & $\left(\cdot / 0 T_{6} \cdot / 09, . / 01\right)$ & 1. & حاكميت قانون & \\
\hline$\cdot / 1 \wedge$ & $(\cdot / r \cdot ، \cdot / 19, \cdot / 1 \wedge)$ & 1 & دسترسى به اطلاعات عمومى & \multirow{10}{*}{ دستور كار } \\
\hline$\cdot / \mu r$ & $(\cdot / \cdot r \wedge / r \Delta \cdot \cdot / r q)$ & r & توافق عمو مى & \\
\hline$\cdot / O r$ & $(\cdot / \Delta 1, \cdot / \Delta \Delta, \cdot / \Delta \cdot)$ & r & شفافيت & \\
\hline$\cdot / \mathrm{IV}$ & $(\cdot / 19 ، \cdot / 10, \cdot / 18)$ & r & رسيدگى و جبران & \\
\hline$\cdot / Q T$ & $(\cdot / \Delta 1, \cdot / 00 \cdot \cdot / 0 \cdot)$ & 0 & انصاف اجتماعى & \\
\hline •/Or & $\left(\cdot / 0 r_{6} \cdot 109 ، \cdot 101\right)$ & 4 & برابرى اجتماعى & \\
\hline$\cdot / 09$ & $(\cdot / \Delta 9, \cdot / \Delta 0, \cdot / 0 \%)$ & V & مسئوليتيذيرى & \\
\hline$\cdot / \sqrt{ } q$ & $(\cdot / 09 ، \cdot / 14 ، \cdot / 90)$ & $\wedge$ & 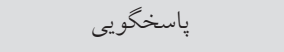 & \\
\hline$\cdot / \mu r$ & $\left(\cdot / r \Lambda_{6} \cdot / r \Delta, \cdot / r q\right)$ & 9 & كارايى و اثربخشى & \\
\hline$\cdot / \wedge \wedge$ & $(\cdot / r \cdot ، \cdot / 19 \cdot(\cdot / \Lambda)$ & 1. & حاكميت قانون & \\
\hline$\cdot / Q F$ & $\left(\cdot / \Delta r_{6} \cdot / \Delta V ، \cdot / \Delta r\right)$ & 1 & دسترسى به اطلاعات عمومى & \multirow{10}{*}{ شاكل گين و } \\
\hline$\cdot / Q F$ & $(\cdot / \Delta r, \cdot / \Delta \Delta, \cdot / \Delta r)$ & r & توافق عمومى & \\
\hline$\cdot / \Delta r$ & $(\cdot / \Delta 1, \cdot / \Delta 0, \cdot / 0 \cdot)$ & r & 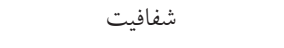 & \\
\hline$\cdot / \mu r$ & $(\cdot / r, \cdot / r \Delta \cdot \cdot / r q)$ & r & رسيدگى و جبران & \\
\hline$\cdot / Q F$ & $(\cdot / \Delta T, \cdot / \Delta Q, \cdot / \Delta F)$ & 0 & انصاف اجتماعى & \\
\hline$\cdot / 09$ & $(\cdot / \Delta Q ، \cdot / \Delta D, \cdot / \Delta F)$ & 4 & برابرى اجتماعى & \\
\hline$\cdot / \mathrm{Vq}$ & $(\cdot / 09 ، \cdot / 14 ، \cdot / 90)$ & V & مسئوليتيذيرى & \\
\hline$\cdot / \Lambda F$ & $\left(\cdot / 9 \mu_{6} \cdot / \Lambda \Lambda, 1\right)$ & $\wedge$ & ياسخگُ يى & \\
\hline 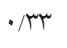 & $(\cdot / r V ، \cdot / K \Psi, \cdot / r \Lambda)$ & 9 & كارايى و اثربخشى & \\
\hline.$/ 40$ & $(\cdot / 4 \pi, \cdot / 4 \Delta, \cdot / 4 \varphi)$ & 1. & حاكميت قانون & \\
\hline
\end{tabular}

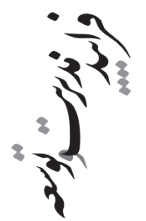

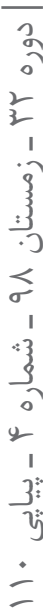


ادامه جدول "ّ: ديد كاه خبر كان در خصوص خدمات عمومى نوين در جرخه خطمشى تذارى بر

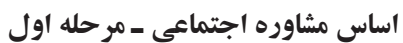

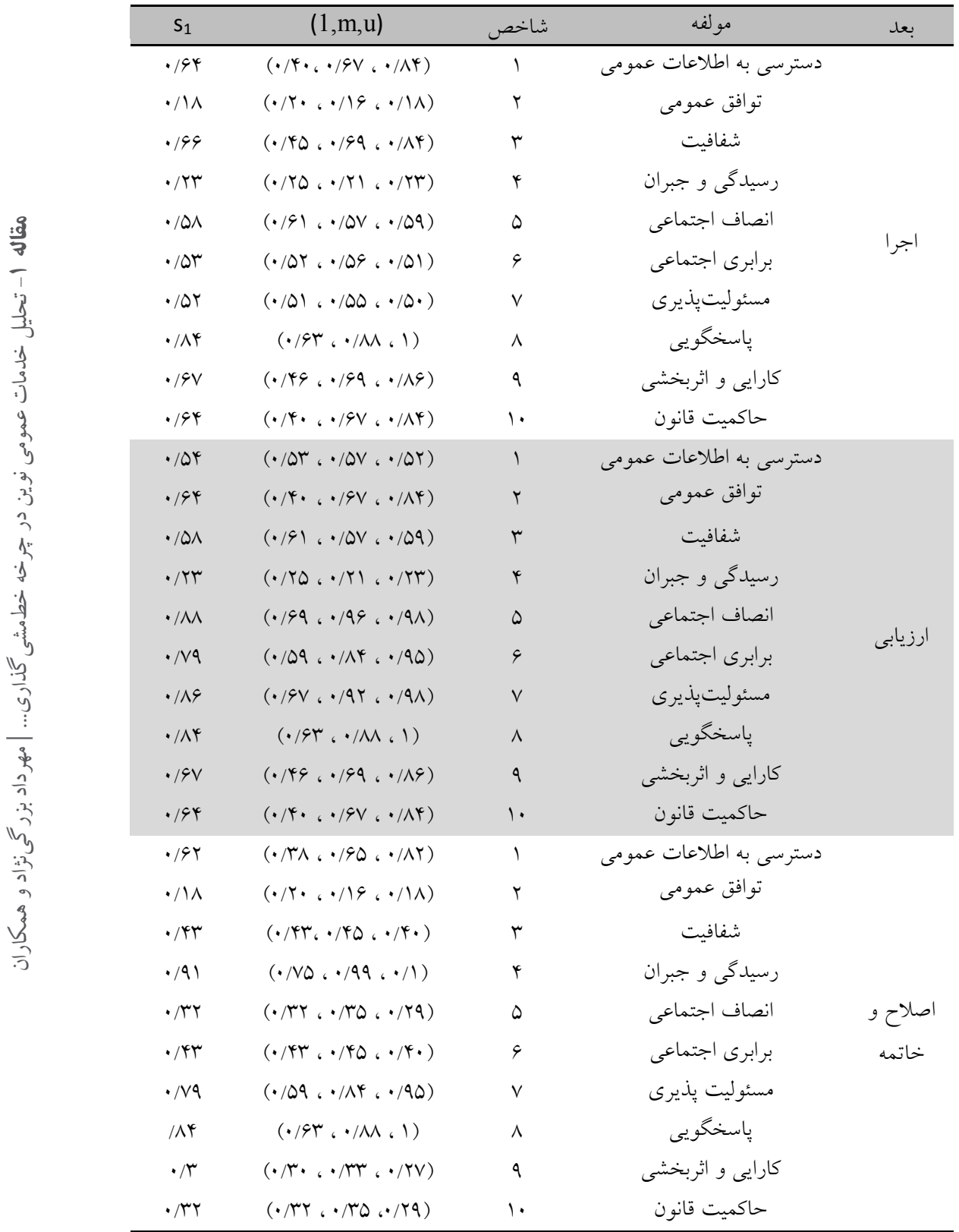


جدول †: ديد كاه خبر كان در خصوص خدمات عمومى نوين در جرخه خطمشى كذارى بر اساس

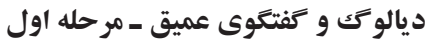

\begin{tabular}{|c|c|c|c|c|}
\hline $\mathrm{s}_{1}$ & $(1, \mathrm{~m}, \mathrm{u})$ & شاخص & مولفه & بعد \\
\hline$\cdot / \wedge \varepsilon$ & $(\cdot / 7 r, \cdot / M \Lambda \cdot 1)$ & 1 & دسترسى به اطلاعات عمو مى & \multirow{10}{*}{ درى مشكاسيى و } \\
\hline$\cdot / \Lambda \Lambda$ & $(\cdot / 79 ، \cdot / 97 ، \cdot / 91)$ & r & توافق عمومى & \\
\hline.$/ 1$ & $(\cdot / 4 \cdot ، \cdot / 17 ، \cdot / 11)$ & r & شفافيت & \\
\hline.$/ 17$ & $(\cdot / r \cdot, \cdot / r \cdot \cdot / / 7)$ & $\varepsilon$ & رسيدگى و جبران & \\
\hline 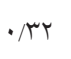 & $(\cdot / r /, \cdot / r 0 ، \cdot / r q)$ & 0 & انصاف اجتماعى & \\
\hline$\cdot / N r$ & $(\cdot / 0 \cdot, \cdot / V 0, \cdot / 9 \varepsilon)$ & 7 & برابرى اجتماعى & \\
\hline$\cdot / \wedge \varepsilon$ & $(\cdot / 7 r \cdot \cdot / M \Lambda \cdot 1)$ & v & مسئوليت يذيرى & \\
\hline$\cdot / T V$ & $(\cdot / r \Lambda ، \cdot / r \cdot ، \cdot / T r)$ & $\wedge$ & ياسخگويى & \\
\hline.$/ \mathrm{V}$ & $(\cdot / 19, \cdot / 10, \cdot / 18)$ & 9 & كارايى و اثربخشى & \\
\hline$\cdot / 20$ & $\left.\left(\cdot / \varepsilon \Psi_{6} \cdot / 20 ، \cdot / 2\right\rceil\right)$ & 1. & حاكميت قانون & \\
\hline.$/ 14$ & $(\cdot / \cdot \cdot \bullet / / \varepsilon, \cdot / T)$ & 1 & دسترسى به اطلاعات عمومى & \multirow{10}{*}{ د - مستور كار } \\
\hline.$/ 17$ & $(\cdot / r \cdot ، \cdot / r \cdot . / 17)$ & r & توافق عمومى & \\
\hline$\cdot / r r$ & $\left(\cdot / r r_{a} \cdot / r 0, \cdot / r q\right)$ & r & شفافيت & \\
\hline.$/ 1 \mathrm{r}$ & $(\cdot / 1 \cdot ، / / \varepsilon, \cdot / / r)$ & $\varepsilon$ & رسيدگى و جبران & \\
\hline$\cdot / r \varepsilon$ & $(\cdot / r \wedge, \cdot / r 0 \cdot \cdot / r q)$ & 0 & انصاف اجتماعى & \\
\hline$\cdot / r \varepsilon$ & $\left(\cdot / r \wedge, \cdot / \sim_{0} \cdot \cdot / r q\right)$ & 7 & برابرى اجتماعى & \\
\hline.$/ 77$ & $(\cdot / \varepsilon 0, \cdot / 79, \cdot / \wedge \varepsilon)$ & $v$ & مسئوليتيذيرى & \\
\hline$\cdot / \Lambda \Lambda$ & $(\cdot / 79 ، \cdot / 97 ، \cdot / 91)$ & $\wedge$ & ياسخخويى & \\
\hline$\cdot / T V$ & $(\cdot / 19 ، \cdot / r V ، \cdot / r 7)$ & 9 & كارايى و اثربخشى & \\
\hline • & $(\cdot / r 0, \cdot / r) \cdot \cdot / r r)$ & 1. & حاكميت قانون & \\
\hline$\cdot / \varepsilon r$ & $(\cdot / \varepsilon r \cdot \cdot / \varepsilon 0, \cdot / \varepsilon \cdot)$ & 1 & دسترسى به اطلاعات عمومى & \multirow{10}{*}{ تدوين و شكل } \\
\hline.$/ 91$ & $(\cdot / 20, \cdot / 99 ، \cdot / 1)$ & r & 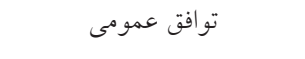 & \\
\hline$\cdot / 20$ & $\left(\cdot / \varepsilon r_{6} \cdot / 20 ، \cdot / \varepsilon 7\right)$ & r & 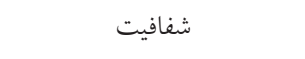 & \\
\hline.$/ 4$ & $(\cdot / 1 \cdot, / / \varepsilon, \cdot / / r)$ & $\varepsilon$ & رسيدگى و جبران & \\
\hline$\cdot / \wedge \varepsilon$ & $(\cdot / 7 r, \cdot / \Lambda \Lambda, ~ 1)$ & ० & انصاف اجتماعى & \\
\hline$\cdot / \wedge \varepsilon$ & $(\cdot / \pi, ، / 1 \Lambda ، 1)$ & 7 & برابرى اجتماعى & \\
\hline$\cdot / \Lambda \Lambda$ & $(\cdot / 79 ، \cdot / 97 ، \cdot / 91)$ & v & مسئوليتيذيرى & \\
\hline$\cdot / 17$ & $(\cdot / 7 V ، \cdot / 9 T \cdot \cdot / 9 \Lambda)$ & $\wedge$ & ياسخكويى & \\
\hline . & $(\cdot / r 0 \cdot \cdot / r) \cdot \cdot / r r)$ & 9 & كارايى و اثربخشى & \\
\hline$\cdot / 7 \varepsilon$ & $(\cdot / \varepsilon \cdot ، \cdot / \mathrm{TV}, \cdot / \wedge \varepsilon)$ & 1. & حاكميت قانون & \\
\hline
\end{tabular}


ادامه جدول fا: ديد Fاه خبر Fان در خصوص خدمات عمومى نوين در جرخه خط مشى كذارى بر

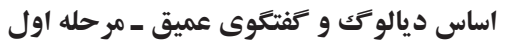

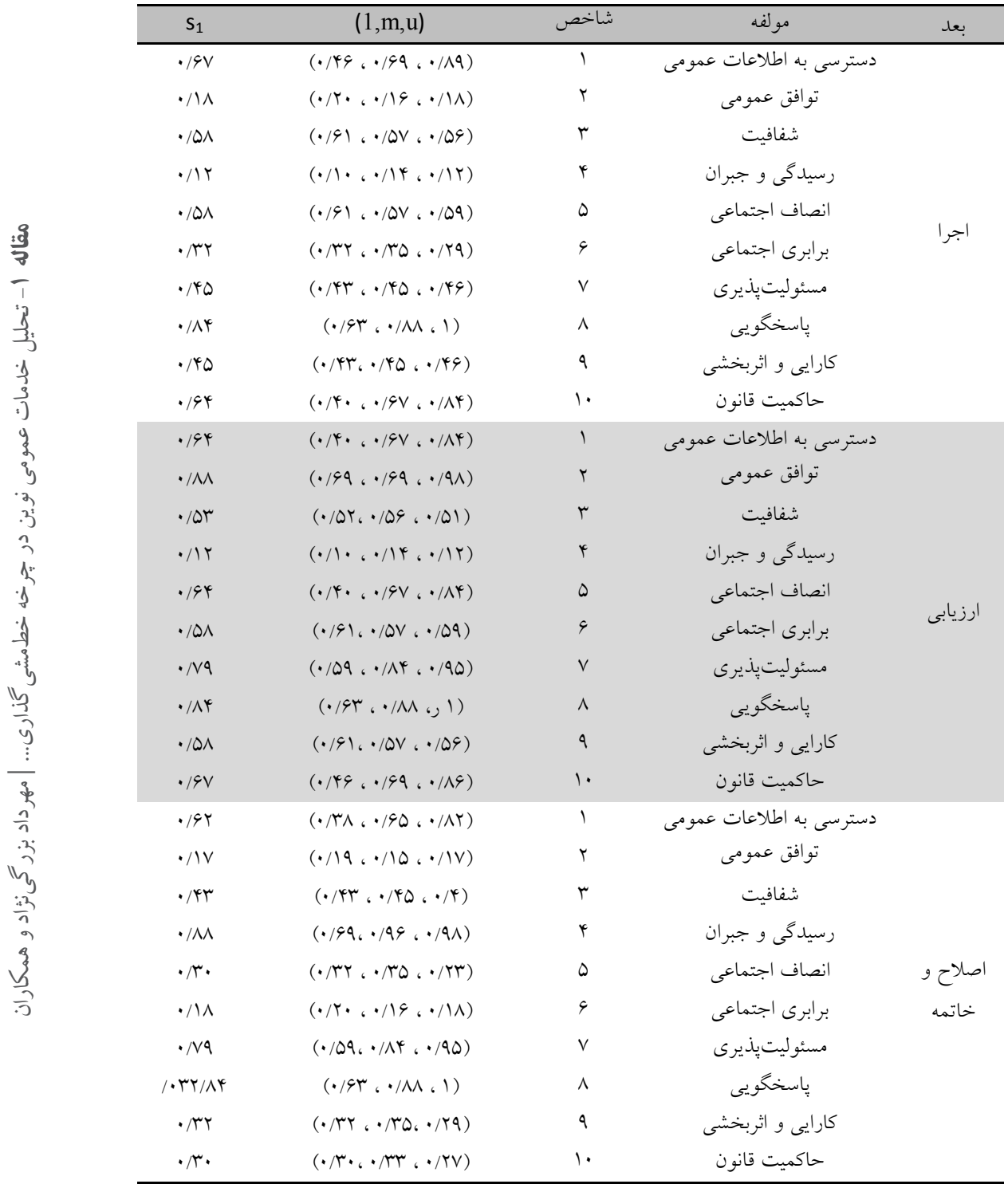


جدول ه: ديد كاه خبر كان در خصوص خدمات عمومى نوين در جرخه خطمشى كذارى بر اساس

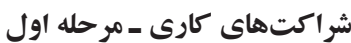

\begin{tabular}{|c|c|c|c|c|}
\hline $\mathrm{s}_{1}$ & $(1, \mathrm{~m}, \mathrm{u})$ & شاخص & مولفه & بعد \\
\hline$\cdot / \kappa \varepsilon$ & $(\cdot / r \wedge, \cdot / r 0, \cdot / r q)$ & 1 & دسترسى به اطلاعات عمومى & \\
\hline$\cdot / 2 r$ & $(\cdot / \varepsilon r, \cdot / \varepsilon 0, \cdot / \varepsilon)$ & r & توافق عمومى & \\
\hline$\cdot / 17$ & $(\cdot / r \cdot, \cdot / 1 r \cdot \cdot / / 7)$ & $r$ & شفافيت & \\
\hline$\cdot / \mathrm{V}$ & $(\cdot / 19 ، \cdot / 10, \cdot / 18)$ & $\varepsilon$ & رسيدگى و جبران & \\
\hline$\cdot / \Lambda$ & $(\cdot / r \cdot, \cdot / 17 ، \cdot / 11)$ & 0 & انصاف اجتماعى & شناسايى و \\
\hline •/ $/ \varepsilon$ & $(\cdot / \varepsilon \cdot, \cdot / \mathrm{TV}, \cdot / \wedge \varepsilon)$ & 7 & برابرى اجتماعى & درى مشكل \\
\hline$\cdot / 77$ & $(\cdot / 20, \cdot / 79, \cdot / \wedge \varepsilon)$ & v & مسئوليتيذيرى & \\
\hline$\cdot / r V$ & $(\cdot / 19 ، \cdot / r V, \cdot / \pi 7)$ & $\wedge$ & ياسخگ يَيى & \\
\hline$\cdot / 17$ & $(\cdot / r \cdot, \cdot / / r \cdot \cdot / / 7)$ & 9 & كارايى و اثربخشى & \\
\hline$\cdot / \kappa \varepsilon$ & $(\cdot / r \Lambda, \cdot / r 0, \cdot / r q)$ & 1. & حاكميت قانون & \\
\hline$\cdot / 17$ & $(\cdot / r \cdot, \cdot / / r \cdot \cdot / / 7)$ & 1 & دسترسى به اطلاعات عمومى & \\
\hline$\cdot / 1 r$ & $(\cdot / 1 \cdot, \cdot / \varepsilon \varepsilon, \cdot / r)$ & r & تو افق عمومى & \\
\hline$\cdot / r V$ & $(\cdot / 19, \cdot / T V, \cdot / r 7)$ & r & شفافيت & \\
\hline • $/$ r & $\left(\cdot / r_{0}, \cdot / r 1, \cdot / r r\right)$ & $\varepsilon$ & رسيدگى و جبران & \\
\hline$\cdot / 20$ & $(\cdot / \pi, \cdot / 20, \cdot / 27)$ & ० & انصاف اجتماعى & دستو, كا, \\
\hline$\cdot / \kappa$ & $(\cdot / r \Lambda, \cdot / r \circ \cdot \cdot / r q)$ & 7 & برابرى اجتماعى & \\
\hline$\cdot / 7 \varepsilon$ & $(\cdot / \varepsilon \cdot, \cdot / 7 V, \cdot / \wedge \varepsilon)$ & v & مسئوليت يذيرى & \\
\hline$\cdot / 77$ & $(\cdot / 20 \cdot / 79, \cdot / \wedge \varepsilon)$ & $\wedge$ & ياسخكويى & \\
\hline$\cdot / 17$ & $(\cdot / r \cdot, \cdot / / r \cdot \cdot / / 7)$ & 9 & كارايى و اثربخشى & \\
\hline$\cdot / r r$ & $\left(\cdot / r_{0}, \cdot / r 1, \cdot / r r\right)$ & 1. & حاكميت قانون & \\
\hline$\cdot / \kappa \varepsilon$ & $\left(\cdot / r \Lambda_{6} \cdot / r 0 \cdot \cdot / r q\right)$ & 1 & دسترسى به اطلاعات عمومى & \\
\hline$\cdot / 20$ & $(\cdot / \pi, \cdot \cdot / 20, \cdot / \varepsilon 7)$ & r & توافق عمومى & \\
\hline$\cdot / r V$ & $(\cdot / 19 ، \cdot / T V ، \cdot / \pi 7)$ & r & شفافيت & \\
\hline$\cdot / r$ & $(\cdot / \cdot, \cdot / \Omega \varepsilon ، \cdot / r)$ & $\varepsilon$ & رسيدگى و جبران & \\
\hline • & $(\cdot / r T, \cdot / r 0, \cdot / r q)$ & 0 & انصاف اجتماعى & تدوين و شكل \\
\hline . $/ 0 r$ & $(\cdot / 0 r, \cdot / 07 ، \cdot 101)$ & 7 & برابرى اجتماعى & كيرى \\
\hline$\cdot 101$ & $(\cdot / 71 ، \cdot / 0 \mathrm{~V}, \cdot / 07)$ & v & مسئوليت يذيرى & \\
\hline$• / 77$ & $(\cdot / \varepsilon 0 ، \cdot / 74 ، \cdot / \wedge \varepsilon)$ & $\wedge$ & ياسخكويى & \\
\hline$\cdot / 17$ & $(\cdot / r \cdot, \cdot / r, \cdot / / 7)$ & 9 & كارايى و اثربخشى & \\
\hline$\cdot / 20$ & $(\cdot / \varepsilon \Gamma, \cdot / 20, \cdot / \varepsilon\rceil)$ & 1. & حاكميت قانون & \\
\hline
\end{tabular}


ادامه جدول ه: ديد Fاه خبر Fان در خصوص خدمات عمومى نوين در جرخه خطمشى كذارى بر اساس شراكتهاى كارى ــمرحله اوحل حمول

\begin{tabular}{|c|c|c|c|c|}
\hline $\mathrm{S}_{1}$ & $(1, \mathrm{~m}, \mathrm{u})$ & شاخص & مولفه & بعد \\
\hline$\cdot / \mu r$ & $(\cdot / r \wedge, \cdot / r \Delta, \cdot / r q)$ & 1 & دسترسى به اطلاعات عمومى & \multirow{10}{*}{ |جرا } \\
\hline$\cdot / 1 \wedge$ & $(\cdot / r \cdot ، \cdot / 19 ، \cdot / 1 \Lambda)$ & t & توافق عمومى & \\
\hline$\cdot / r q$ & $(\cdot / r 1 \cdot \cdot / r V \cdot \cdot / r q)$ & r & 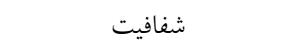 & \\
\hline$\cdot / \wedge$ & $(\cdot / 4 \cdot ، \cdot / 19 ، \cdot / 1 \Lambda)$ & r & رسيدگى و جبران & \\
\hline$\cdot / \wedge \Lambda$ & $(\cdot / 99 ، \cdot / 99 ، \cdot / 91)$ & 0 & انصاف اجتماعى & \\
\hline$\cdot / \Lambda 4$ & $(\cdot / 9 \mu, \cdot / \Lambda \Lambda \cdot 1)$ & 9 & برابرى اجتماعى & \\
\hline$\cdot / 91$ & $(\cdot / N 0, \cdot / 99 \cdot 1)$ & V & مسئوليتيذيرى & \\
\hline$\cdot / \mathrm{Vq}$ & $(\cdot / 096 \cdot / 14 ، \cdot / 90)$ & $\wedge$ & ياسخخويى & \\
\hline$\cdot / \mathrm{A} \wedge$ & $\left(\cdot / \Delta \wedge ، \cdot / \wedge r_{6} \cdot / Q r\right)$ & 9 & كارايى و اثربخشى & \\
\hline$\cdot / \Delta \wedge$ & $(\cdot / 91 ، \cdot / 0 V, ، / 09)$ & 1. & حاكميت قانون & \\
\hline$\cdot / \mu x$ & $(\cdot / r \Lambda \cdot \cdot / r \Delta \cdot \cdot / r q)$ & 1 & دسترسى بـ اطلاعات عمو مى & \multirow{10}{*}{ 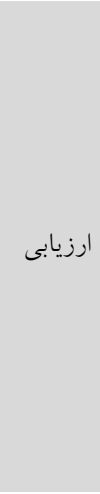 } \\
\hline$\cdot d r$ & $\left(\cdot / r r^{\prime} \cdot / r \Delta \cdot \cdot / r q\right)$ & r & توافق عمومى & \\
\hline$\cdot / r$ & $(\cdot / r \Delta \cdot \cdot / r 1 \cdot(r r)$ & r & 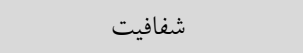 & \\
\hline$\cdot / r r$ & 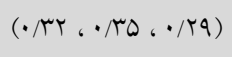 & r & رسيدكى و جبران & \\
\hline$\cdot / 0 \wedge$ & $(\cdot / 91, \cdot 10 V \cdot \cdot / 09)$ & 0 & انصاف اجتماعى & \\
\hline$\cdot 19 \mathrm{~V}$ & $(\cdot / 49 ، \cdot / 99 ، \cdot / 19)$ & 9 & برابرى اجتماعى & \\
\hline$\cdot / 4 r$ & $\left(\cdot / 4 \Psi_{0} \cdot / 4 Q, \cdot / 4 \cdot\right)$ & V & مسئوليتيذيرى & \\
\hline$\cdot / v 9$ & $(\cdot / 09 ، \cdot / 14 ، \cdot / 90)$ & $\wedge$ & ياسخخويى & \\
\hline$\cdot / \Delta \wedge$ & $(\cdot / 91, \cdot / 0 V ، \cdot 109)$ & 9 & كارايى و اثربخشى & \\
\hline •/or & $(\cdot / 0 T ، \cdot 109 ، \cdot 101)$ & 1. & حاكميت قانون & \\
\hline$\cdot / \mu x$ & $\left(\cdot / r \Lambda_{6} \cdot / r \omega_{\bullet} \cdot / r q\right)$ & 1 & دسترسى به اطلاعات عمومى & \multirow{10}{*}{ خاتمه و } \\
\hline$\cdot / \Lambda$ & $(\cdot / r \cdot ، \cdot / 19 \cdot \cdot / 11)$ & r & توافق عمومى & \\
\hline$\cdot / 1 \wedge$ & $(\cdot / r \cdot ، \cdot / 19 \cdot \cdot / 11)$ & r & 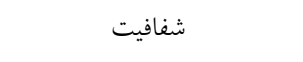 & \\
\hline$\cdot / 0 \Lambda$ & $(\cdot / 91 ، \cdot / 0 V ، \cdot 109)$ & r & رسيدگى و جبران & \\
\hline$\cdot / \mu$ & $(\cdot / r \cdot \bullet / r r, ~ • / r V)$ & 0 & انصاف اجتماعى & \\
\hline Th & $(\cdot / r T ، / r \Delta, \cdot / r q)$ & 9 & برابرى اجتماعى & \\
\hline$\cdot / 40$ & $(\cdot / 4 \pi, \cdot / 4 \Delta, \cdot / 4 \varphi)$ & v & مسئوليتيذيرى & \\
\hline$\cdot / 14$ & $(\cdot / 9 \mu, \cdot / \Lambda \Lambda \cdot 1)$ & $\wedge$ & ياسخگويى & \\
\hline$\cdot / 1 \mathrm{r}$ & $(\cdot / 1 \cdot ، \cdot / r+a / / r)$ & 9 & كارايى و اثربخشى & \\
\hline$\cdot / 1 \wedge$ & $(\cdot / 4 \cdot 6 \cdot / 19 \cdot \cdot / 11)$ & $1 \cdot$ & حاكميت قانون & \\
\hline
\end{tabular}

سبِ براى هر خبره، مقدار اختلاف از ميانخين بر اساس فرمول (أ) محاسبه مىشود.

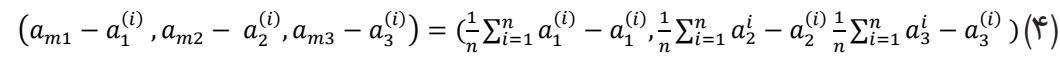


جدول 9: اختلاف از ميانكين در خصوص خدمات عمومى نوين در جرخه خطمشى تذارى بر اساس ارتباط يكسويه ـ مرحله اول

\begin{tabular}{|c|c|c|c|c|}
\hline اختلاف ازخين & $\mathrm{s}_{1}$ & شاخص & 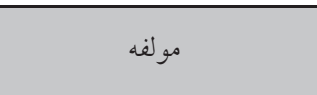 & بعد \\
\hline$\cdot / r \Lambda$ & $\cdot / 19$ & 1 & دسترسى به اطلاعات عمومى & \multirow{10}{*}{ درى مشكلاسيى و } \\
\hline$-\cdot / \pi \Delta$ & $\cdot / \pi$ & r & توافق عمومى & \\
\hline - & $\cdot \pi \Delta$ & r & شفافيت & \\
\hline$-\cdot / \mu 1$ & $\cdot / r V$ & $r$ & رسيدگى و جبران & \\
\hline.$- / \cdot 9$ & - /Or & 0 & انصاف اجتماعى & \\
\hline$-\cdot / \cdot r$ & $\cdot 109$ & 9 & برابرى اجتماعى & \\
\hline$-\cdot / \cdot r$ & $\cdot / 09$ & v & مسئوليت پِذيرى & \\
\hline$-\cdot / r q$ & $\cdot / \pi 9$ & $\wedge$ & ياسخگ & \\
\hline$-\cdot / \mu \Delta$ & $\cdot / \pi$ & 9 & كارايى و اثربخشى & \\
\hline$\cdot / 49$ & $\cdot / A r$ & 1. & حاكميت قانون & \\
\hline$-\cdot / 4$ & $\cdot / \wedge \wedge$ & 1 & دسترسى به اطلاعات عمومى & \multirow{10}{*}{ دستور كار } \\
\hline$-\cdot / 1$ & $\cdot / 4 \wedge$ & r & توافق عمومى & \\
\hline 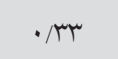 & $\cdot / 91$ & r & شفافيت & \\
\hline 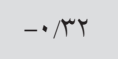 & $\cdot / T^{4}$ & r & رسيدگى و جبران & \\
\hline$-.1 \cdot 9$ & $\cdot / \Delta r$ & 0 & انصاف اجتماعى & \\
\hline$-\cdot / \cdot 0$ & $\cdot / \Delta r$ & 9 & برابرى اجتماعى & \\
\hline$\cdot / r \wedge$ & $\cdot / 19$ & 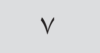 & مسئوليت يذيرى & \\
\hline$\cdot / r \mid$ & $\cdot / N 9$ & $\wedge$ & ياسخكويى & \\
\hline-.119 & $\cdot k r$ & 9 & كارايى و اثربخشى & \\
\hline$-\cdot / T Y$ & $\cdot \pi r$ & 1. & حاكميت قانون & \\
\hline$\cdot / T Q$ & $\cdot / \Lambda r$ & 1 & دسترسى به اطلاعات عمومى & \multirow{10}{*}{ شكل كين و } \\
\hline$-\cdot / \cdot \varphi$ & $\cdot / \Delta r$ & r & 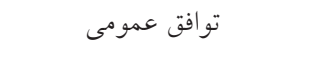 & \\
\hline$\cdot / r \Lambda$ & $\cdot / 19$ & r & 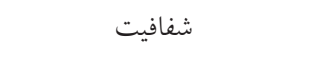 & \\
\hline$-\cdot / T \Delta$ & $\cdot \pi$ & $r$ & رسيدگى و جبران & \\
\hline$-\cdot / \cdot r$ & $\cdot / 09$ & $\Delta$ & انصاف اجتماعى & \\
\hline . & $\cdot / \Delta \wedge$ & 9 & برابرى اجتماعى & \\
\hline.$- / \cdot 4$ & $\cdot / \Delta r$ & v & مسئوليت يذيرى & \\
\hline$\cdot / 1$ & $\cdot / 91$ & $\wedge$ & باسخخُويى & \\
\hline$-\cdot / Y Y$ & $\cdot \pi r$ & 9 & كارايى و اثربخشى & \\
\hline$\cdot / v a$ & $\cdot / \mathrm{Na}$ & 1. & حاكميت قانون & \\
\hline
\end{tabular}

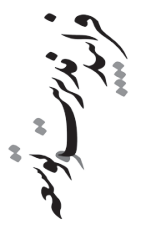


ادامه جدول \&: اختلاف از ميانكين در خصوص خدمات عمومى نوين در جرخه خطمشى حذارى بر

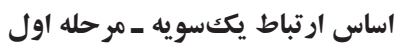

\begin{tabular}{|c|c|c|c|c|}
\hline اختانلاف ازين & $\mathrm{s}_{1}$ & شاخص & 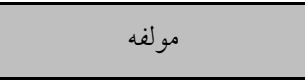 & بعد \\
\hline$\cdot / 19$ & $\cdot / \mathrm{VV}$ & 1 & دسترسى به اطلاعات عمومى & \multirow{10}{*}{ اجرا } \\
\hline$-\cdot / 14$ & $\cdot / 4 x$ & r & توافق عمومى & \\
\hline$\cdot / r$ & $\cdot / M$ & r & شفافيت & \\
\hline$-\cdot / r \Lambda$ & $\cdot / \mu$ & r & رسيدگى و جبران & \\
\hline$\cdot / \cdot \wedge$ & .194 & 0 & انصاف اجتماعى & \\
\hline.$/ .9$ & $.19 \mathrm{~V}$ & 4 & برابرى اجتماعى & \\
\hline$\cdot / \cdot 0$ & $\cdot 194$ & v & مسئوليتيذيرى & \\
\hline$\cdot / \cdot \wedge$ & $\cdot 199$ & $\wedge$ & ياسخكويى & \\
\hline.$/ . r$ & .191 & 9 & كارايى و اثربخشى & \\
\hline$\cdot / 49$ & $\cdot / \Lambda 4$ & 1. & حاكميت قانون & \\
\hline$\cdot \pi r$ & $\cdot / 9$ & 1 & دسترسى به اطلاعات عمومى & \multirow{10}{*}{ ارزيابى } \\
\hline$-\cdot / \cdot 0$ & . /Or & r & تو ت ع افق عمومى & \\
\hline 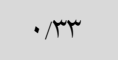 & $\cdot / 91$ & r & 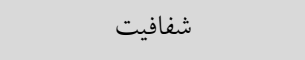 & \\
\hline$-\cdot / 49$ & $\cdot \pi r$ & r & رسيدگى و جبران & \\
\hline$-\cdot / \cdot r$ & $\cdot / 09$ & 0 & انصاف اجتماعى & \\
\hline$-\cdot / \cdot r$ & $\cdot / 00$ & 4 & برابرى اجتماعى & \\
\hline$\cdot / r 1$ & $\cdot / \mathrm{Q} 9$ & v & مسئوليتيذيرى & \\
\hline$\cdot / r 1$ & $\cdot / \mathrm{Va}$ & $\wedge$ & ياسخكويى & \\
\hline$\cdot 1 \cdot 0$ &.$/ 94$ & 9 & كارايى و اثربخشى & \\
\hline$\cdot / T \Lambda$ & $\cdot / 19$ & 1. & حاكميت قانون & \\
\hline$\cdot / 10$ & $\cdot / N$ & 1 & دسترسى به اطلاعات عمومى & \multirow{10}{*}{ خاتمه } \\
\hline$-\cdot / \Gamma \Delta$ & • & r & تو افق عمومى & \\
\hline$\cdot / 19$ & $\cdot / \mathrm{VV}$ & r & شفافيت & \\
\hline$\cdot / r \wedge$ & $\cdot / 19$ & r & رسيدگى و جبران & \\
\hline$-\cdot / 49$ & $\cdot / r T$ & 0 & انصاف اجتماعى & \\
\hline$-\cdot / 49$ & $\cdot / r$ & 4 & برابرى اجتماعى & \\
\hline$\cdot / 14$ & $\cdot / V T$ & $\checkmark$ & مسئوليتيذيرى & \\
\hline$\cdot / \Lambda$ & $\cdot / \sqrt{ } 4$ & $\wedge$ & ياسخكويى & \\
\hline$-\cdot 119$ & $\cdot / 4 r$ & 9 & كارايى و اثربخشى & \\
\hline$-\cdot / T Y$ & $\cdot / \mu r$ & 1. & حاكميت قانون & \\
\hline
\end{tabular}


جدول Y: اختلاف از ميانكين در خصوص خدمات عمومى نوين در جرخه خطمشى تذارى بر اساس مشاوره اجتماعى - مرحله اول خدمان

\begin{tabular}{|c|c|c|c|c|}
\hline اختاناف از & $\mathrm{s}_{1}$ & شاخص & 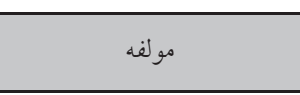 & بعد \\
\hline$\cdot / \pi 7$ & $\cdot / M \Lambda$ & 1 & دسترسى به اطلاعات عمومى & \multirow{10}{*}{ درى مشكل } \\
\hline$\cdot / r 1$ & $\cdot / N r$ & r & تو افق عمومى & \\
\hline 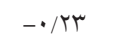 & $\cdot / \pi 9$ & r & شفافيت & \\
\hline$-\cdot / 49$ & $\cdot / \pi$ & $\varepsilon$ & رسيدگى و جبران & \\
\hline.$- / T_{0}$ & $\cdot / r V$ & 0 & انصاف اجتماعى & \\
\hline$-\cdot / T_{0}$ & $\cdot / T V$ & 7 & برابرى اجتماعى & \\
\hline$\cdot / T_{0}$ & $\cdot / \mathrm{VV}$ & 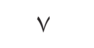 & مسئوليتيذيرى & \\
\hline.$- / T_{0}$ & $\cdot / r V$ & $\wedge$ & 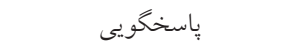 & \\
\hline$-\cdot / r 9$ & . & 9 & كارايى و اثربخشى & \\
\hline.$/ 1$ &.$/ 0 r$ & 1. & حاكميت قانون & \\
\hline$-\cdot / r \varepsilon$ & $\cdot / \wedge$ & 1 & دسترسى به اطلاعات عمومى & \multirow{10}{*}{ دستور كار } \\
\hline$-\cdot / 1 \wedge$ & $\cdot / \varepsilon$ & r & توافق عمومى & \\
\hline · & $\cdot / 0 r$ & r & شفافيت & \\
\hline.$- / r_{0}$ & $\cdot / I V$ & $\varepsilon$ & رسيدگى و جبران & \\
\hline . & $.10 \mathrm{r}$ & ० & انصاف اجتماعى & \\
\hline.$/ \cdot 1$ & $\cdot / 0 r$ & 7 & برابرى اجتماعى & \\
\hline$\cdot / \cdot \varepsilon$ & .107 & v & مسئوليتيذيرى & \\
\hline$\cdot / T V$ & $\cdot / v 9$ & $\wedge$ & 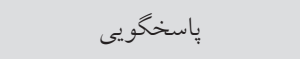 & \\
\hline$-\cdot / 1 \wedge$ & $\cdot \pi \varepsilon$ & 9 & كارايى و اثربخشى & \\
\hline$-\cdot \pi \varepsilon$ & $\cdot / \wedge$ & 1. & حاكميت قانون & \\
\hline$\% r$ & $\cdot 10 \varepsilon$ & 1 & دسترسى به اطلاعات عمومى & \multirow{10}{*}{ شكل كَين وى } \\
\hline$\bullet \cdot r$ & $\cdot 10 \varepsilon$ & r & 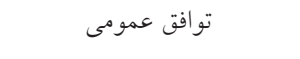 & \\
\hline . & $\cdot 10 \mathrm{r}$ & r & شفافيت & \\
\hline$-\cdot / r$ & $\cdot / r r$ & $\varepsilon$ & رسيدگى و جبران & \\
\hline 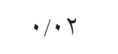 & $.10 \varepsilon$ & ० & انصاف اجتماعى & \\
\hline$\cdot / \cdot \varepsilon$ &.$/ 07$ & 7 & برابرى اجتماعى & \\
\hline$\cdot / T V$ & $\cdot / \mathrm{Na}$ & $v$ & مسئوليتيذيرى & \\
\hline$\cdot / \pi r$ & $\cdot / \wedge \varepsilon$ & $\wedge$ & ياسخگُويى & \\
\hline$-\cdot / 19$ & 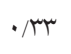 & 9 & كاريى و اثربخشى & \\
\hline$-\bullet / \cdot v$ & $\cdot / 20$ & 1. & حاكميت قانون & \\
\hline
\end{tabular}


ادامه جدول Y: اختلاف از ميانكين در خصوص خدمات عمومى نوين در جرخه خطمشى تذارى بر اساس مشاوره اجتماعى ـ مرحله اول

\begin{tabular}{|c|c|c|c|c|}
\hline ميانكين اختلاف از & $\mathrm{S}_{1}$ & شاخص & 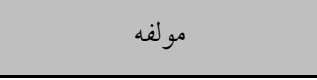 & بعد \\
\hline$\cdot / 14$ & $\cdot / 7 \varepsilon$ & 1 & دسترسى به اطلاعات عمومى & \multirow{10}{*}{ اجرا | اجرا } \\
\hline$-\cdot / \mu \varepsilon$ & $\cdot / 1 \wedge$ & r & توافق عمومى & \\
\hline$\cdot / \varepsilon$ & $\cdot / 77$ & r & شفافيت & \\
\hline$-\cdot / 7 q$ & $\cdot \pi r$ & $\varepsilon$ & رسيدگى و جبران & \\
\hline$\cdot 1 \cdot 7$ & $\cdot 101$ & 0 & انصاف اجتماعى & \\
\hline$\cdot / \cdot 1$ & $\cdot / 0 r$ & 7 & برابرى اجتماعى & \\
\hline . & $\cdot / 0 r$ & v & مسئوليت ٍِيرى & \\
\hline$\cdot \pi r$ & $\cdot / \wedge \varepsilon$ & $\wedge$ & ياسخكويى & \\
\hline .110 & $\cdot / 7 V$ & 9 & كارايى و اثربخشى & \\
\hline$\cdot / 14$ & $\cdot / 7 \varepsilon$ & 1. & حاكميت قانون & \\
\hline$\cdot / \cdot r$ & $.10 \varepsilon$ & 1 & دسترسى به اطلاعات عمومى & \multirow{10}{*}{ 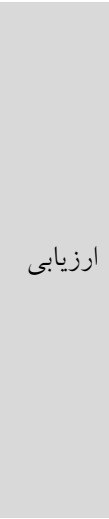 } \\
\hline$\cdot / r$ & $\cdot / 7 \varepsilon$ & r & 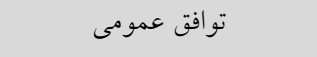 & \\
\hline$\cdot / \cdot 7$ & $\cdot 101$ & r & 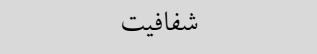 & \\
\hline$-\cdot / r q$ & • & $\varepsilon$ & رسيدكى و جبران & \\
\hline$\cdot \pi$ & $\cdot / \Lambda \Lambda$ & ० & انصاف اجتماعى & \\
\hline$\cdot / T V$ & $\cdot / \mathrm{Va}$ & 7 & برابرى اجتماعى & \\
\hline$\cdot \pi \varepsilon$ & $\cdot / 117$ & v & مسئوليت يذيرى & \\
\hline$\cdot \pi r$ & $\cdot / \wedge \varepsilon$ & $\wedge$ & ياسخگُويى & \\
\hline$\cdot / 10$ & $\cdot / 7 V$ & 9 & كارايى و اثربخشى & \\
\hline$\cdot / 1 \mathrm{r}$ & $\cdot / 7 \varepsilon$ & 1. & حاكميت قانون & \\
\hline$\cdot / 1$ & $\cdot / 7 r$ & 1 & دسترسى به اطلاعات عمومى & \multirow{10}{*}{ خاتمه } \\
\hline$-\cdot / \Gamma \varepsilon$ & $\cdot / 1 \wedge$ & r & 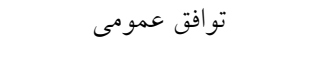 & \\
\hline$-\cdot / \cdot 9$ & $\cdot / \varepsilon r$ & r & شفافيت & \\
\hline$\cdot / 4 q$ &.$/ 91$ & $\varepsilon$ & رسيدگى و جبران & \\
\hline$-\cdot / r$ & $\cdot \pi t$ & $\circ$ & انصاف اجتماعى & \\
\hline$-\cdot / \cdot 9$ & $\cdot / \varepsilon r$ & 7 & برابرى اجتماعى & \\
\hline$\cdot / r V$ & $\cdot / \mathrm{Va}$ & 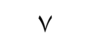 & مسئوليت يذيرى & \\
\hline 每 & $/ \wedge \varepsilon$ & $\wedge$ & ياسخخويى & \\
\hline$-\cdot / r T$ & $\cdot r$ & 9 & كارايى و اثربخشى & \\
\hline$-\cdot / r$ & • & 1. & حاكميت قانون & \\
\hline
\end{tabular}


جدول A: اختلاف از ميانكين در خصوص خدمات عمومى نوين در جرخه خطمشى تذارى بر اساس كفتتوى عميق ـ مرحله اول خمومات نوين

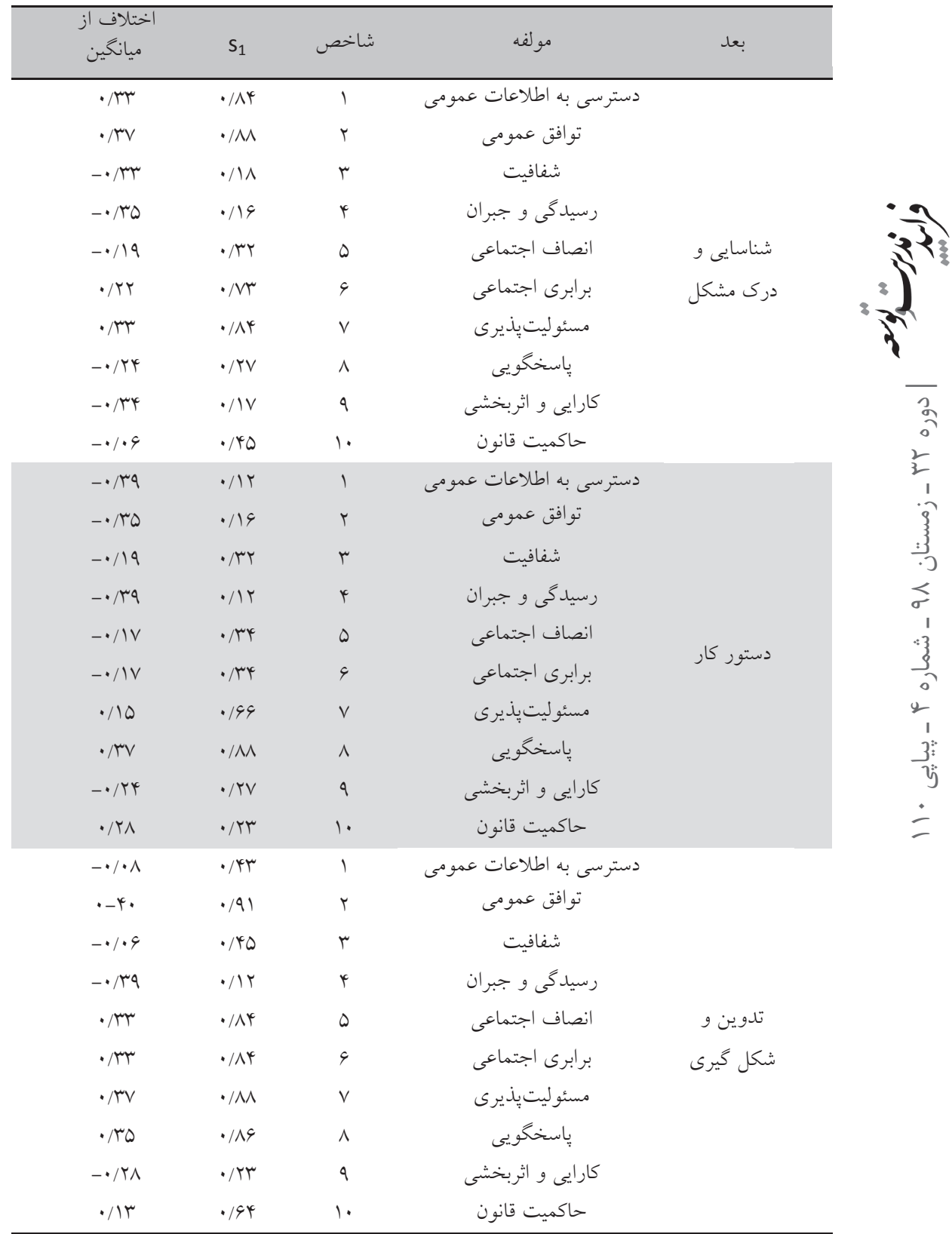


ادامه جدول ^: اختلاف از ميانكين در خصوص خدمات عمومى نوين در جرخه خطمشى تذارى بر اساس كنتخوى عميق ـ مرحله اول

\begin{tabular}{|c|c|c|c|c|}
\hline اخيانكين از & $s_{1}$ & 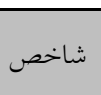 & 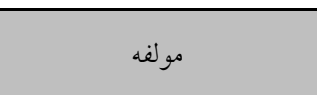 & بعد \\
\hline .119 & $.19 \mathrm{~V}$ & 1 & دسترسى به اطلاعات عمومى & \multirow{10}{*}{ اجرا } \\
\hline 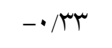 & $\cdot / 1 \wedge$ & r & توافق عمومى & \\
\hline$\cdot / \cdot v$ & $\cdot / \Delta \Lambda$ & r & شفافيت & \\
\hline$-\cdot / r q$ &.$/ 1 \mathrm{r}$ & $r$ & رسيدگى و جبران & \\
\hline$\cdot / \cdot v$ & $\cdot / \Delta \Lambda$ & 0 & انصاف اجتماعى & \\
\hline$-\cdot / 19$ & $\cdot \pi r$ & 4 & برابرى اجتماعى & \\
\hline$-.1 \cdot 4$ & $\cdot / 40$ & $v$ & مسئوليت پيذيرى & \\
\hline 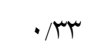 & $\cdot / N F$ & $\wedge$ & ياسخغويى & \\
\hline$-\cdot 1 \cdot 9$ & $\cdot / 4 \Delta$ & 9 & كارايى و اثربخشى & \\
\hline 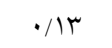 & $\cdot 194$ & 1. & حاكميت قانون & \\
\hline$\cdot / 14$ & .194 & 1 & دسترسى به اطلاعات عمومى & \multirow{10}{*}{ 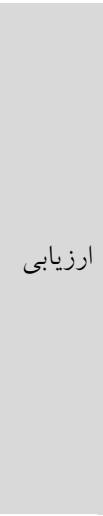 } \\
\hline$\cdot / r V$ & $\cdot / M$ & r & توافق عمومى & \\
\hline$\cdot / \cdot r$ & $\cdot / \Delta r$ & r & شفافيت & \\
\hline$-\cdot / r q$ & $\cdot / r$ & r & رسيدگى و جبران & \\
\hline 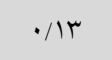 & .194 & $\Delta$ & انصاف اجتماعى & \\
\hline$\cdot / \cdot v$ & $\cdot / \Delta \wedge$ & 9 & برابرى اجتماعى & \\
\hline$\cdot / r \Lambda$ & $\cdot / \mathrm{Na}$ & v & مسئوليتيذيرى & \\
\hline 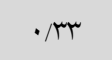 & $\cdot / \Lambda F$ & $\wedge$ & 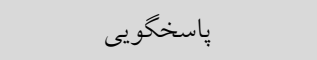 & \\
\hline$\cdot / \cdot v$ & $\cdot / 01$ & 9 & كارايى و اثربخشى & \\
\hline$\cdot / 19$ & $\cdot 19 \mathrm{~V}$ & 1. & حاكميت قانون & \\
\hline.$/ 11$ & $\cdot / 94$ & 1 & دسترسى به اطلاعات عمومى & \multirow{10}{*}{ خاتمه } \\
\hline$-\cdot / \mu r$ & $\cdot / I V$ & r & تو افق عمومى & \\
\hline$-\cdot / \cdot \wedge$ & 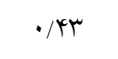 & r & 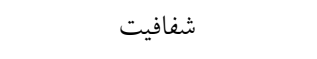 & \\
\hline$\cdot / \pi v$ & $\cdot / M$ & $r$ & رسيدگى و جبران & \\
\hline$-\cdot / r 1$ & $\cdot r \cdot$ & $\Delta$ & انصاف اجتماعى & \\
\hline 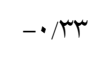 & $\cdot / 1 \wedge$ & 4 & برابرى اجتماعى & \\
\hline$\cdot / T \Lambda$ & $\cdot / \mathrm{Na}$ & $v$ & مسئوليتيذيرى & \\
\hline 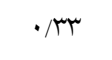 & /.MT/AY & $\wedge$ & ياسخخويى & \\
\hline$-\cdot / 19$ & $\cdot \pi r$ & 9 & كارايى و اثربخشى & \\
\hline$-\cdot / r \mid$ & $\cdot \pi \cdot$ & 1. & حاكميت قانون & \\
\hline
\end{tabular}


جدول 9: اختلاف از ميانكين خدمات عمومى نوين در جرخه خطمشى كذارى بر اساس شراكتهاى

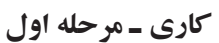

\begin{tabular}{|c|c|c|c|c|}
\hline اختلاف از & $\mathrm{S}_{1}$ & شاخص & 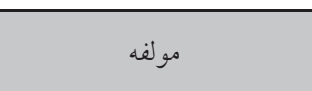 & بعد \\
\hline$-\cdot 1 \cdot 4$ & $\cdot / \mu^{\mu}$ & 1 & دسترسى به اطلاعات عمومى & \multirow{20}{*}{ شناسايى و } \\
\hline • & $\cdot / M$ & r & تو افق عمومى & \\
\hline$-\cdot / Y Y$ &.$/ 19$ & r & 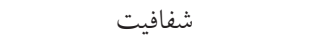 & \\
\hline 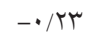 & $\cdot / \mathrm{VV}$ & q & رسيدگى و جبران & \\
\hline$-\cdot / r T$ & $\cdot / \wedge$ & $\Delta$ & انصاف اجتماعى & \\
\hline$\cdot / Y Y$ & $\cdot / 94$ & 9 & برابرى اجتماعى & \\
\hline$\cdot / 49$ & .199 & V & مسئوليتيذيرى & \\
\hline$-\cdot / 1 r$ & $\cdot / T V$ & $\wedge$ & 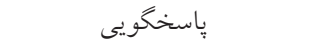 & \\
\hline$-\cdot / Y Y$ & .119 & 9 & كار ايى و اثربخشى & \\
\hline-.1 .9 & $\cdot \pi r$ & 1. & حاكميت قانون & \\
\hline$-\cdot / T Y$ &.$/ 19$ & 1 & دسترسى به اطلاعات عمومى & \\
\hline$-\cdot / Y \wedge$ &.$/ r$ & t & توافق عمومى & \\
\hline - & $\cdot / T V$ & r & شفافيت & \\
\hline$-\cdot / 1 \mathrm{~V}$ & 每 & r & رسيدكى و جبران & \\
\hline$\cdot 1 \cdot 0$ & $\cdot / 4 \Delta$ & $\Delta$ & انصاف اجتماعى & \\
\hline$-\cdot / \cdot 9$ & $\cdot \pi r$ & 9 & برابرى اجتماعى & \\
\hline$\cdot / T Y$ &.$/ 94$ & V & مسئو ليتيذيرى & \\
\hline$\cdot 1 / 4$ & .199 & $\wedge$ & ياسخخويى & \\
\hline$-\cdot / T Y$ & .119 & 9 & كارايى و اتربخشى & \\
\hline$-\cdot / 1 \mathrm{~V}$ & • & 1. & حاكميت قانون & \\
\hline-.1 .9 & $\cdot / \mu r$ & 1 & \multirow{10}{*}{ دسترسى به اطلاعات عمومى توافق عمومى شفافيت } & \multirow{10}{*}{ شكل كيرى } \\
\hline$\cdot / \cdot \Delta$ & $\cdot / 4 \Delta$ & r & & \\
\hline$-\cdot / 1 r$ & $\cdot / T V$ & r & & \\
\hline$-\cdot /$ 个 &.$/ r$ & y & & \\
\hline$-\cdot / \cdot \wedge$ & $\cdot \pi r$ & $\Delta$ & & \\
\hline$\cdot / 1 r$ & •/Or & 4 & & \\
\hline$\cdot / 1 \wedge$ & $\cdot / \Delta \wedge$ & V & & \\
\hline$\cdot 1 / 49$ & .199 & $\wedge$ & & \\
\hline$\cdot / T Y$ & .119 & 9 & & \\
\hline$\cdot / \cdot \Delta$ & $\cdot / 4 \Delta$ & 1. & & \\
\hline
\end{tabular}


ادامه جدول 9: اختلاف از ميانكين خدمات عمومى نوين در جرخه خطمشى تذارى بر اساس

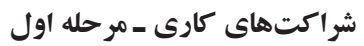

\begin{tabular}{|c|c|c|c|c|}
\hline ميانكين اخلاف از & $\mathrm{s}_{1}$ & شاخص & 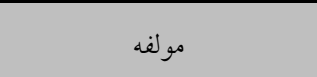 & بعد \\
\hline.$- / \cdot 7$ & $\cdot / \pi \varepsilon$ & 1 & دسترسى به اطلاعات عمومى & \multirow{10}{*}{ |جر| } \\
\hline$-\cdot / r Y$ & $\cdot / \Lambda$ & r & توافق عمومى & \\
\hline$-\cdot / 11$ & $\cdot / r q$ & r & شفافيت & \\
\hline$-\cdot / Y T$ & $\cdot / 1 \wedge$ & $\varepsilon$ & رسيدگى و جبران & \\
\hline$\cdot / \varepsilon \wedge$ & $\cdot / \Lambda$ & 0 & انصاف اجتماعى & \\
\hline$\cdot / \varepsilon \varepsilon$ & $\cdot / \wedge \varepsilon$ & 7 & برابرى اجتماعى & \\
\hline .101 & $\cdot / 91$ & $v$ & مسئوليت يذيرى & \\
\hline$\cdot / \pi q$ & $\cdot / \mathrm{Va}$ & $\wedge$ & ياسخكويى & \\
\hline$\cdot / \mu$ & $\cdot / \mathrm{V} \wedge$ & 9 & كارايى و اثربخشى & \\
\hline$\cdot / \Lambda$ & $\cdot 101$ & 1. & حاكميت قانون & \\
\hline$-\cdot / \cdot 7$ & $\cdot / \kappa \varepsilon$ & 1 & دسترسى به اطلاعات عمومى & \multirow{10}{*}{ ارزيابى } \\
\hline$-\cdot / \cdot \wedge$ & • & r & توافق عمومى & \\
\hline$-\cdot / I V$ & - & $r$ & شفافيت & \\
\hline$-\cdot / \cdot \wedge$ & • & $\varepsilon$ & رسيدگى و جبران & \\
\hline$\cdot / 1 \wedge$ & $\cdot 101$ & 0 & انصاف اجتماعى & \\
\hline$\cdot / r V$ & $\cdot / 7 V$ & 7 & برابرى اجتماعى & \\
\hline$\cdot / \cdot r$ & $\cdot / \varepsilon r$ & v & مسئوليت يذيرى & \\
\hline$\cdot / / q$ & $\cdot / / 9$ & $\wedge$ & ياسخخُويى & \\
\hline$\cdot / \Lambda$ & $\cdot / 01$ & 9 & كارايى و اثربخشى & \\
\hline ./r & . /or & 1. & حاكميت قانون & \\
\hline$-\cdot / \cdot 7$ & $\cdot / \kappa \varepsilon$ & 1 & دسترسى به اطلاعات عمومى & \multirow{10}{*}{ اصاتمه و و } \\
\hline$-\cdot / T r$ & $\cdot / 1 \wedge$ & r & توافق عمومى & \\
\hline$-\cdot / r Y$ & $\cdot / 1 \Lambda$ & r & شفافيت & \\
\hline$\cdot / \Lambda$ & $\cdot 101$ & $\varepsilon$ & رسيدگى و جبران & \\
\hline$-\cdot / 1$ & $\cdot / r$ & 0 & انصاف اجتماعى & \\
\hline$-\cdot / \cdot \wedge$ & D & 7 & برابرى اجتماعى & \\
\hline .1 .0 & $\cdot / 20$ & v & مسئوليت پذيرى & \\
\hline$\cdot / \varepsilon \varepsilon$ & $\cdot / \wedge \varepsilon$ & $\wedge$ & ياسخگُويى & \\
\hline$-\cdot / r \Lambda$ & $\cdot / r$ & 9 & كارايى و اثربخشى & \\
\hline$-\cdot / r r$ & $\cdot / \Lambda$ & 1. & حاكميت قانون & \\
\hline
\end{tabular}


به منظور تاثير هر يك از مراحل خطمشى گذارى در ابعاد خدمات عمومى نوين و اولويت كذارى

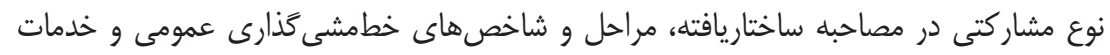

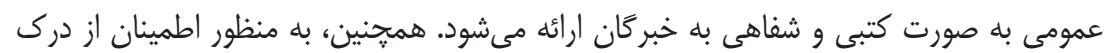
صحيح شاخصها و ياسخكويى به هر برسش، شاخصهاى مرتبط دوباره مورد تاكيد قرار مى گيرد.

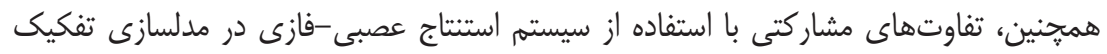
مىشود. در مرحله دوم از روش دلفى فازى با هدف مشخص شدن مقدار توافق بين خبركان،

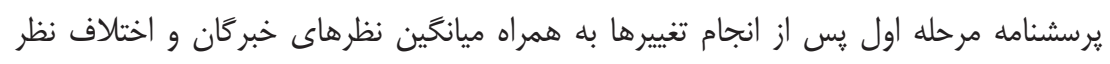

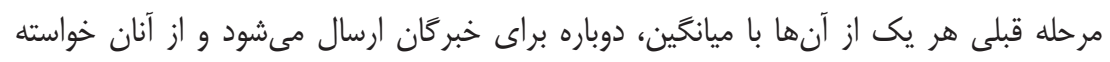

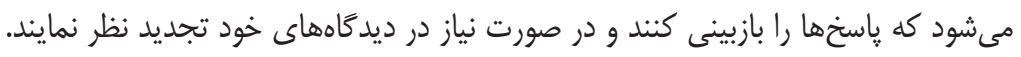

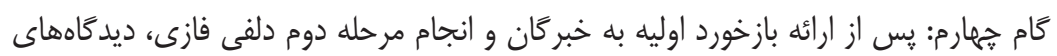

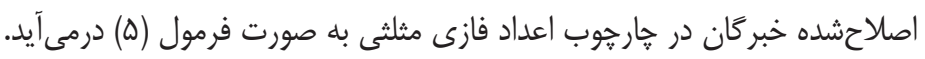
$\tilde{B}^{(i)}=\left(b_{1}^{(i)}, b_{2}^{(i)}, b_{3}^{(i)}\right) \quad i=1,2,3 \ldots . n$ در اين كام نيز هماند كام دوم، در مرحله دوم دلفى فازى ميانگَين ديدًاه اصلاحشده خبركان با فرمول (ع) محاسبه مىشود. كام ينجم: فازىزدايى كردن. از روش مركز ثقل بر اساس فرمول (V)، براى فازىزدايى استفاده $S_{j}=\frac{u_{j}+m_{j}+i_{j}}{3}$

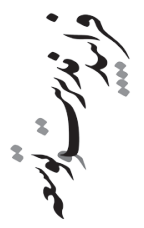

كام ششه: محاسبه مقدار اختلاف نظر خبركان در دو مرحله. مقدار اختلاف بر اساس فرمول

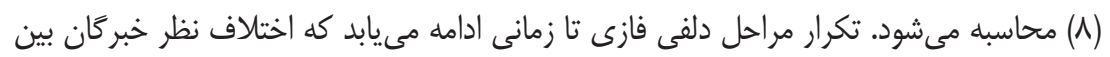

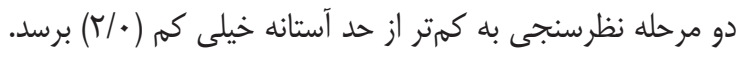
$S\left(\tilde{B}_{m}, \tilde{A}_{m}=\left[\frac{1}{3}\left[\left(b_{m 1}, b_{m 2}, b_{m 3}\right)-\left(a_{m 1}, a_{m 2}, a_{m 3}\right)\right]\right.\right.$ 


\section{جدول • ا: ديدكاه خبر كان در خصوص خدمات عمومى نوين در جرخه خطمشى كذارى بر اساس ارتباط يكسويه ـ مرحله دوم}

\begin{tabular}{|c|c|c|c|c|c|}
\hline $\mathrm{s}_{1}-\mathrm{s}_{2}$ & $\mathrm{~s}_{1}$ & $(1, \mathrm{~m}, \mathrm{u})$ & شاخص & 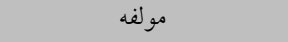 & بعد \\
\hline$\cdot / \cdot 0$ & $\cdot / 11$ & $(\cdot / 9 \cdot, \cdot / 9 \cdot, \cdot / 90)$ & 1 & دسترسى به اطلاعات عمومى & \multirow{10}{*}{ و ش درى } \\
\hline$\cdot / \cdot 1$ & $\cdot \pi r$ & $(\cdot / r Y, \cdot / r \cdot, \cdot / r r)$ & r & تو افق عمومى & \\
\hline$\cdot / \cdot r$ & $\cdot \pi r$ & $(\cdot / \mu) \cdot \cdot / \mu^{4} \cdot(\cdot / \cdot)$ & r & شفافيت & \\
\hline$\cdot / \cdot r$ & $\cdot \pi \Delta$ & $(\cdot / 19, \cdot / T V ،, / r r)$ & $r$ & رسيدگى و جبران & \\
\hline$\cdot / \cdot 1$ &.$/ 01$ & $\left(\cdot / \Delta \cdot, \cdot / \Delta \sigma_{6} \cdot / / q\right)$ & $\Delta$ & انصاف اجتماعى & \\
\hline$\cdot / \cdot 4$ & . $/ 0 T$ & $\left(\cdot / \Delta r_{1} \cdot / \Delta r_{6} \cdot / \Delta I\right)$ & 9 & برابرى اجتماعى & \\
\hline$\cdot / \cdot \vee$ &.$/ 49$ & $(\cdot / 4 q, \cdot / \Delta 0, \cdot / 44)$ & $v$ & مسئوليتيذيرى & \\
\hline$\cdot 1 \cdot 0$ & $\cdot / \pi r$ & $(\cdot / r) \cdot \cdot / T Q, \cdot / r V)$ & $\wedge$ & ياسخگكويى & \\
\hline.$/ \cdot 9$ & $\cdot / / V$ & $(\cdot / 10, \cdot / 19 \cdot \cdot / r 1)$ & 9 & كارايى و اثربخشى & \\
\hline$\cdot / \cdot 4$ & $\cdot / \wedge$ & $(\cdot / \Delta r, \cdot / M \Lambda, 1)$ & 1. & حاكميت قانون & \\
\hline$\cdot / \cdot r$ &.$/ 19$ & $(\cdot / 19, \cdot / 14, \cdot / 10)$ & 1 & دسترسى به اطلاعات عمومى & \multirow{10}{*}{ كار } \\
\hline$\cdot / \cdot 4$ & $\cdot / 44$ & $(\cdot / \Delta r, \cdot / 4), \cdot / 4 \cdot)$ & r & تو افق عمومى & \\
\hline$\cdot / \cdot V$ & $\cdot / \Lambda 4$ & $(\cdot / 11 \cdot \cdot / 91, \cdot / 9)$ & r & شفافيت & \\
\hline.$/ \cdot 9$ & $\cdot / I V$ & $(\cdot / r 1 \cdot \cdot / 10, \cdot / 19)$ & $r$ & رسيدگى و جبران & \\
\hline$\cdot / \cdot r$ & $\cdot / 4 \Lambda$ & $(\cdot / 4 \varphi, \cdot / \Delta \cdot, \cdot / 4 \Lambda)$ & 0 & انصاف اجتماعى & \\
\hline$\cdot / 1$ & r & $\left(\cdot / 4 r_{0} \cdot / 4 \varphi, \cdot / 41\right)$ & 9 & برابرى اجتماعى & \\
\hline 每 & $\cdot N r$ & $(\cdot / \mu r, \cdot / \wedge \Delta, \cdot / Q T)$ & $v$ & مسئوليتيذيرى & \\
\hline$\cdot / \cdot V$ & $\cdot N T$ & $(\cdot / \Delta 4, \cdot / \wedge \cdot, \cdot / V \Lambda)$ & $\wedge$ & ياسخكويى & \\
\hline.$/ 4$ & $\cdot \pi 4$ & $(\cdot / \cdot r / / 4) \cdot(\cdot / \cdot)$ & 9 & كارايى و اثربخشى & \\
\hline . & $\cdot \pi k$ & $(\cdot / r), \cdot / r q, \cdot / r q)$ & 1. & حاكميت قانون & \\
\hline$\cdot / \cdot 1$ & - $/ A r$ & $(\cdot / 91, \cdot / 9 r, \cdot / 94)$ & 1 & دسترسى به اطلاعات عمومى & \multirow{10}{*}{ شيكل } \\
\hline$\cdot$ & $\cdot / 04$ & $(\cdot / \Delta r, \cdot / 4 \Lambda, \cdot / 4 \varphi)$ & r & تو افق عمومى & \\
\hline.$/ 14$ & $\cdot N r$ & $(\cdot / 90, \cdot / 14, \cdot / 94)$ & r & شفافيت & \\
\hline$\cdot / \cdot 4$ & $\cdot \pi v$ & $(\cdot / r \cdot ، \cdot r \cdot, \cdot / r r)$ & $r$ & رسيدگى و جبران & \\
\hline.$/ .9$ & $\cdot / 4 \mathrm{~V}$ & $(\cdot / 44, \cdot / 4 \Delta, \cdot / \Delta 1)$ & Q & انصاف اجتماعى & \\
\hline$\cdot / \cdot r$ & $\cdot / \Delta \omega$ & $(\cdot / 09, \cdot / 00, \cdot / \Delta 1)$ & 9 & برابرى اجتماعى & \\
\hline$\cdot / \cdot r$ &.$/ 49$ & $(\cdot / 4 q, \cdot / \Delta 1, \cdot \cdot / 4 v)$ & $v$ & مسئوليت يذ يرى & \\
\hline .1 .9 &.$/ 09$ & $(\cdot / 4), \cdot / q \mu, \cdot / v \theta)$ & $\wedge$ & لِ & \\
\hline $.1 \cdot 9$ & $\cdot / r \Lambda$ & $\left(\cdot / \pi r_{0} \cdot / \Gamma, \cdot / r I\right)$ & 9 & كارايى و اثربخشى & \\
\hline$\cdot / \cdot r$ & $\cdot / \mathrm{V}$ & $\left(\cdot / \Delta Q, \cdot / \Lambda F_{6} \cdot / M \Lambda\right)$ & 1. & حاكميت قانون & \\
\hline
\end{tabular}


ادامه جدول • ا: ديد كاه خبر كان در خصوص خدمات عمومى نوين در جرخه خطمشى كذارى بر

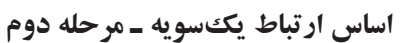

\begin{tabular}{|c|c|c|c|c|c|}
\hline $\mathrm{s}_{1}-\mathrm{s}_{2}$ & $\mathrm{~s}_{1}$ & $(1, \mathrm{~m}, \mathrm{u})$ & شاخص & مولفه & بعد \\
\hline$\cdot / \cdot r$ & $\cdot / V^{4}$ & $\left(\cdot / \Delta Y^{\prime}, / V Q ، \cdot / q T\right)$ & 1 & دسترسى به اطلاعات & \multirow{10}{*}{ |جرا } \\
\hline .1 .9 & - ( & $\left(\cdot / \mu_{1} \cdot / \mu_{1} \cdot \cdot / \mu_{4}\right)$ & r & توافق عمومى & \\
\hline$\cdot / \cdot 1$ & $\cdot / \wedge$ & $(\cdot / 09 ، \cdot 199, \cdot / 199)$ & r & شفافيت & \\
\hline$\cdot / \cdot 0$ & $\cdot / T \Delta$ & $(\cdot / r \Delta, \cdot / r \cdot ، \cdot r l)$ & r & رسيدگى و جبران & \\
\hline$\cdot / \cdot+$ &.$/ 94$ & $(\cdot / 40, \cdot / 91, \cdot / 11)$ & 0 & انصاف اجتماعى & \\
\hline$\cdot / \cdot r$ & $\cdot / 94$ & $(\cdot / 4 r, \cdot / 9 r, \cdot / M \Lambda)$ & 4 & برابرى اجتماعى & \\
\hline .1 .9 & $\cdot / \mathrm{OV}$ & $(\cdot / r q ، \cdot N r \cdot \cdot / V I)$ & v & مسئوليت يذيرى & \\
\hline$\cdot / \cdot 1$ & $\cdot / 0 \Lambda$ & $(\cdot / r q ، \cdot / 9 r ، \cdot / N)$ & $\wedge$ & ياسخخويى & \\
\hline$\cdot / \cdot r$ & $\cdot / 09$ & $(\cdot / / 1 ، \cdot / 91 ، \cdot / 19)$ & 9 & كارايى و اثربخشى & \\
\hline . & $\cdot / \Lambda F$ & $\left(\cdot / 94 ، \cdot / 1 V_{6} \cdot \cdot / 9 \cdot\right)$ & 1. & حاكميت قانون & \\
\hline . & $\cdot / 9$ & $\left(\cdot / r^{r}, \cdot / 9 \Lambda \cdot \cdot / 1\right)$ & 1 & دسترسى به اطلاعات & \multirow{10}{*}{ ارزيابى } \\
\hline $.1 \cdot 9$ & - / ky & $(\cdot / 49, \cdot / 4 r, \cdot / 4 r)$ & r & تو افَ عمومى & \\
\hline$\cdot / \cdot 1$ & $\cdot / 9$ & $\left(\cdot / V^{4}, \cdot / 91, \cdot / 99\right)$ & r & شفافيت & \\
\hline$\cdot / \cdot r$ & $\cdot / r$ & ()$^{*}$, • & i & رسيدگى و جبران & \\
\hline.$/ \cdot r$ & $\cdot / O T$ & $(\cdot / 41, \cdot / 4 \wedge, \cdot / 4 q)$ & 0 & انصاف اجتماعى & \\
\hline$\cdot / \cdot V$ & $\cdot / 4 \wedge$ & $(\cdot / 40, \cdot / 01, \cdot / 4 q)$ & 4 & برابرى اجتماعى & \\
\hline$\cdot / \cdot V$ & $\cdot / V T$ & $(\cdot / 4 \wedge, \cdot / \wedge l \cdot \cdot / \wedge q)$ & v & مسئوليتيذيرى & \\
\hline . & $\cdot / \mathrm{Vq}$ & $(\cdot / 09, \cdot / 14, \cdot / 90)$ & $\wedge$ & ياسخگويى & \\
\hline $.1 \cdot 9$ & $\cdot / Q V$ & $(\cdot / r \cdot ، \cdot / q \mu, \cdot / \vee q)$ & 9 & كارايى و اثربخشى & \\
\hline$\cdot 1 \cdot 0$ & $\cdot / \wedge \mid$ & $(\cdot / 91, \cdot / 97 . \cdot / 91)$ & 1. & حاكميت قانون & \\
\hline $.1 \cdot 9$ & $.19 \mathrm{~V}$ & $\left(\cdot / 4 r_{6} \cdot / r^{\prime}, \cdot / M \Lambda\right)$ & 1 & دسترسى به اطلاعات & \multirow{10}{*}{ هاتمه } \\
\hline$\cdot / \cdot+$ & .119 & $\left(\bullet / 19 ، \cdot / 11, \cdot / r_{\bullet}\right)$ & r & توافت عمومى & \\
\hline$\cdot / 4$ & $\cdot / N$ & $(\cdot / 01 ، \cdot / V 9 ، \cdot / 94)$ & r & 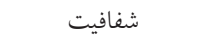 & \\
\hline$\cdot / \cdot 4$ & $\cdot / A T$ & $(\cdot / 90 ، \cdot / 9 r ، \cdot / 91)$ & y & رسيدگى و جبران & \\
\hline$\cdot / \cdot r$ & $\cdot / r q$ & $(\cdot / \Gamma \Delta, ، / \Gamma) ، / \pi)$ & 0 & انصاف اجتماعى & \\
\hline$\cdot / \cdot V$ & $\cdot / r \Delta$ & $(\cdot / r \wedge ، \cdot / r \Delta ، \cdot r r)$ & 4 & برابرى اجتماعى & \\
\hline$\cdot / \cdot r$ &.$/ 99$ & $(\cdot / 4) \cdot \cdot / V r \cdot \cdot / q 4)$ & v & مسئوليتيذيرى & \\
\hline$. / \cdot+$ & $\cdot / V Y$ & $(\cdot / 0 \cdot 6 \cdot / 71, \cdot / 94)$ & $\wedge$ & ياسخخويى & \\
\hline$. / \cdot+$ & $\cdot / \mu \wedge$ & $\left.(\cdot / 4), \cdot / 4+6 / r^{\prime}\right)$ & 9 & كارايى و اثربخشى & \\
\hline.$/ \cdot 4$ & $\cdot / r$ & $(\cdot / r V ، \cdot / r \cdot(r l)$ & 1. & حاكميت قانون & \\
\hline
\end{tabular}

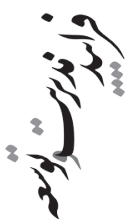

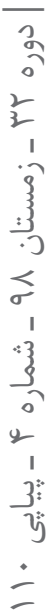




\section{جدول |1: ديدكاه خبر كان در خصوص خدمات عمومى نوين در جرخه خطمشى كذارى بر اساس مشاوره اجتماعى ـ مرحله دوم}

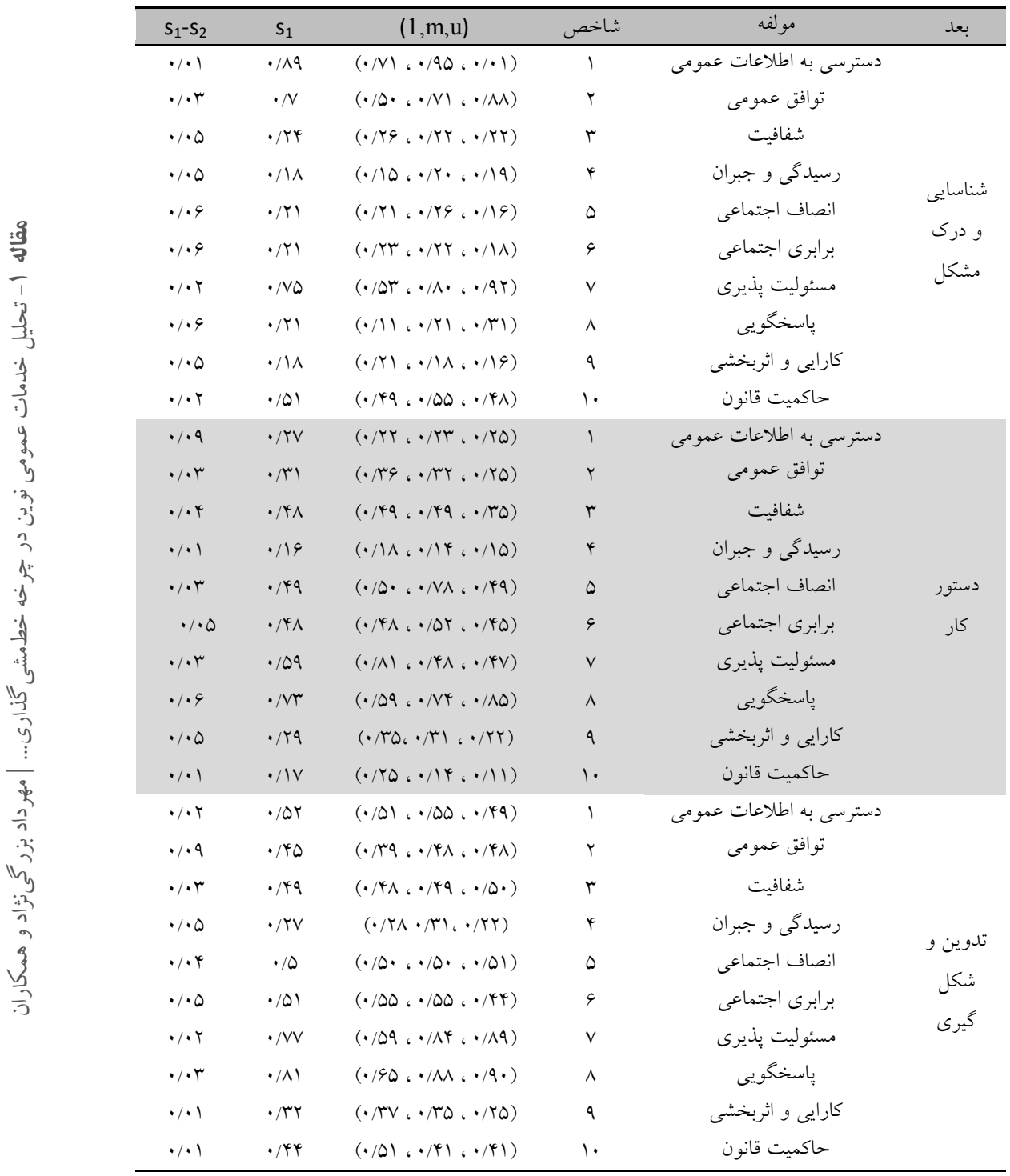


ادامه جدول ا ا: ديد كاه خبر Fان در خصوص خدمات عمومى نوين در جرخه خطمشى حذارى بر

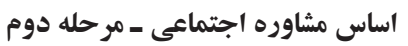

\begin{tabular}{|c|c|c|c|c|c|c|}
\hline $\mathrm{S}_{1}-\mathrm{S}_{2}$ & $\mathrm{~S}_{1}$ & $(1, \mathrm{~m}, \mathrm{u})$ & شاخص & مولفه & بعد & \\
\hline$\cdot / \cdot 1$ & . & $(\cdot / 40, \cdot / 99, \cdot / N 4)$ & 1 & دسترسى به اطلاعات & \multirow{10}{*}{ |جر| } & \\
\hline$\cdot / \cdot \wedge$ & $\cdot /$ TG & $(\cdot / r \cdot ، \cdot / 19 ، \cdot / r \Lambda)$ & r & توافق عمومى & & \\
\hline$\cdot / \cdot r$ & $\cdot 194$ & $\left(\cdot / 4 \Delta, \cdot / 9 r_{0} \cdot / \Lambda 1\right)$ & r & شفافيت & & \\
\hline$\cdot / \cdot r$ &.$/ T Q$ & $\left(\cdot / r Y, \cdot / T Q_{0} \cdot / r \varphi\right)$ & r & رسيدگى و جبران & & \\
\hline$\cdot / \cdot 1$ & $\cdot / 0$ & $(\cdot / 41, \cdot \cdot 101, \cdot \cdot / 09)$ & 0 & انصاف اجتماعى & & \\
\hline$\cdot / \cdot r$ & $\cdot / 01$ & $(\cdot / 01, \cdot / 01, \cdot / \Delta r)$ & 4 & برابرى اجتماعى & & \\
\hline$\cdot / \cdot r$ & $\cdot / \uparrow \wedge$ & $(\cdot / \Delta 1, \cdot / 4 \wedge, \cdot / 4 \Delta)$ & v & مسئوليت يذيرى & & 8 \\
\hline$\cdot / \cdot 4$ & $\cdot / \wedge$ & $(\cdot / 90, \cdot / \Lambda r \cdot(/ 9 r)$ & $\wedge$ & ياسخخويى & & \\
\hline$\cdot / \cdot 1$ & .199 & $(\cdot / v q, \cdot / N 1, \cdot / v q)$ & 9 & كارايى و اثربخشى & & \\
\hline$\cdot / \cdot r$ & $\cdot / 94$ & $\left.(\cdot / r \Delta, \cdot / N)^{\prime} \cdot / v q\right)$ & 1. & حاكميت قانون & & \\
\hline$\cdot / \cdot 4$ & $\cdot / 0$ & $(\cdot / \Delta r, \cdot / \Delta 1, \cdot / 4 \Delta)$ & 1 & دسترسى به اطلاعات & \multirow{10}{*}{ ارزيابى } & 0 \\
\hline.$/ \cdot 0$ & $\cdot / 09$ & $(\cdot / r \Delta, \cdot / q V, \cdot / V \psi)$ & r & توافق عمومى & & $\frac{2}{2}$ \\
\hline$\cdot / \cdot r$ & $\cdot / \Delta \Delta$ & $\left(\cdot / 9 T_{6} \cdot / 01 ، \cdot / 01\right)$ & r & شفافيت & & 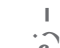 \\
\hline$\cdot 1 \cdot 0$ &.$/ 11$ & $\left(\cdot / 10 \cdot \cdot / 19 \cdot \cdot / r_{\bullet}\right)$ & r & رسيدگى و جبران & & \\
\hline.$/ \cdot 1$ & $\cdot / \wedge \mathrm{V}$ & $(\cdot / 90, \cdot / 91 ، \cdot / 91)$ & 0 & انصاف اجتماعى & & $<$ \\
\hline$\cdot / \cdot \wedge$ & $\cdot / N 1$ & $(\cdot / 4 r, \cdot / \Lambda 1, \cdot \cdot / q \cdot)$ & 4 & برابرى اجتماعى & & 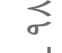 \\
\hline.$/ \cdot r$ & $\cdot / \Lambda Y^{k}$ & $(\cdot / 996 \cdot / 9 \cdot 6 \cdot / 9 r)$ & v & مسئوليت يذيرى & & $\because 3$ \\
\hline r & $\cdot / 11$ & $(\cdot / 90, \cdot /$ VA, 1$)$ & $\wedge$ & ياسخگويى & & 3 \\
\hline .1 .9 & $\cdot / N$ & $(\cdot / \wedge q \cdot / 4 \Delta, \cdot / \wedge \Delta)$ & 9 & كارايى و اثربخشى & & $y_{1}$ \\
\hline$\cdot 1 \cdot 1$ & .190 & $\left(\cdot / \Delta F_{6} \cdot / 9 \mid, \cdot / \Lambda \cdot\right)$ & 1. & حاكميت قانون & & 3 \\
\hline$\cdot / \cdot 1$ & .191 & $\left(\cdot / r q_{6} \cdot / 9 \cdot \sigma \cdot / \wedge \Delta\right)$ & 1 & دسترسى به اطلاعات & \multirow{10}{*}{ خاتمه } & † \\
\hline$\cdot / \cdot 4$ & • KT & $\left(\cdot / r \Delta_{6} \cdot / T_{6} \cdot / T_{\bullet}\right)$ & r & توافق عمومى & & 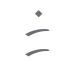 \\
\hline$\cdot / \cdot V$ & . & $(\cdot / 19 ، \cdot / 01 ، \cdot / \Gamma \wedge)$ & r & شفافيت & & \\
\hline$\cdot / \cdot 0$ & $\cdot 199$ & $\left(\cdot / 9 r^{\prime} \cdot / 99 ، \cdot / 91\right)$ & r & رسيدگى و جبران & & \\
\hline$\cdot / \cdot r$ & $\cdot / r q$ & 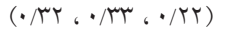 & 0 & انصاف اجتماعى & & \\
\hline$\cdot / \cdot r$ &.$/ 40$ & $(\cdot / 4 \&, \cdot / 94, \cdot / 4 \Delta)$ & 9 & برابرى اجتماعى & & \\
\hline$\cdot / \cdot r$ & $\cdot / \mathrm{VV}$ & $(\cdot / 09 ، \cdot / 11 ، \cdot / 91)$ & V & مسئوليت يذيرى & & \\
\hline$\cdot / \cdot r$ & $\cdot / \wedge 9$ & $(\cdot / \mathrm{V} \wedge, \cdot / 9 \cdot, \cdot / 9 \cdot)$ & $\wedge$ & ياسخگ & & \\
\hline$\cdot 1 \cdot 0$ & $\cdot / \pi \Delta$ & $(\cdot / r \Delta, \cdot / 4 \leftarrow, \cdot / T \Delta)$ & 9 & كارايى و اثربخشى & & \\
\hline$\cdot / \cdot r$ & $\cdot / \pi$ & 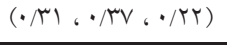 & 1. & حاكميت قانون & & \\
\hline
\end{tabular}




\section{جدول r ا: ديد كاه خبر كان در خصوص خدمات عمومى نوين در جرخه خطمشى كذارى بر اساس كفتتوى عميق ـ مرحله دوم}

\begin{tabular}{|c|c|c|c|c|c|}
\hline$s_{1}-s_{2}$ & $\mathrm{~s}_{1}$ & $(1, \mathrm{~m}, \mathrm{u})$ & شاخص & مولفه & بعد \\
\hline.$/ r$ & $\cdot / \Lambda 1$ & $(\cdot / 91, \cdot / A V, \cdot / 40)$ & 1 & دسترسى به اطلاعات عمومى & \multirow{10}{*}{ و ش درى } \\
\hline .1 .4 & . /Ar & $(\cdot / 91, \cdot / 9 r, \cdot / 94)$ & r & تو افق عمومى & \\
\hline$\% 4$ &.$/ 14$ & $\left(\cdot / 1 r_{6} \cdot / 14, \cdot / 1 Q\right)$ & r & شفافيت & \\
\hline$\% r$ &.$/ 14$ & $(\cdot / r r, \cdot / 1 \cdot(\cdot / 11)$ & $r$ & رسيدكى و جبران & \\
\hline$\cdot / \cdot r$ & $\cdot / \pi q$ & $(\cdot / r q, \cdot / r Q, \cdot / r r)$ & 0 & انصاف اجتماعى & \\
\hline$\% r$ & $\cdot / N 1$ & $(\cdot / 0 \cdot, \cdot / V T \cdot \cdot / 91)$ & 4 & برابرى اجتماعى & \\
\hline.$/ 4$ & $\cdot / \wedge$ & $(\cdot / 94, \cdot / 19, \cdot / 91)$ & $v$ & مسئوليت بذيرى & \\
\hline.$/ . r$ & $\cdot / r y$ & $(\cdot / T V, \cdot / T Q, \cdot / r \cdot)$ & $\wedge$ & ياسخكويى & \\
\hline$\because / r$ &.$/ 10$ & $(\cdot / 1 V ، \cdot / I r, \cdot / 1 Q)$ & 9 & كارايى و اثربخشى & \\
\hline$/ . r$ & . $/ 4$ & $(\cdot / \mu r, \cdot / \mu), \cdot / \mu r)$ & 1. & حاكميت قانون & \\
\hline$\cdot / \cdot 1$ &.$/ 11$ & $(\cdot / 11 ، \cdot / 1 \Gamma, \cdot / 1 \cdot)$ & 1 & دسترسى به اطلاعات عمومى & \multirow{10}{*}{ كار } \\
\hline$\cdot / r$ &.$/ 14$ & $(\cdot / 1 \Lambda, \cdot / 1 \cdot, \cdot / / Q)$ & r & تو افق عمومى & \\
\hline.$/ r$ & $\cdot / r$ & $\left(\cdot / \Gamma I_{1} \cdot / \Gamma \cdot \cdot / \Gamma \Delta\right)$ & r & شفافيت & \\
\hline.$/ \cdot 1$ & $\cdot / 11$ & $(\cdot / 1 \cdot, \cdot / 11, \cdot / 11)$ & $r$ & رسيدگى و جبران & \\
\hline$\cdot / \cdot 4$ & $\cdot / r$ & $(\cdot / \Gamma) \cdot(\pi r, \cdot / r V)$ & $\Delta$ & انصاف اجتماعى & \\
\hline$\cdot / 4$ & $\cdot / r$ & $\left(\cdot / r \cdot, \cdot / r \epsilon_{6} \cdot / r V\right)$ & 9 & برابرى اجتماعى & \\
\hline.$/ 4$ &.$/ 94$ & $(\cdot / 4 r, \cdot / 91, \cdot \cdot / \Lambda r)$ & 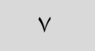 & مسئوليت بذيرى & \\
\hline$\% 4$ & $\cdot / \Lambda F$ & $(\cdot / 94, \cdot / 94, \cdot / 90)$ & $\wedge$ & ياسخكويى & \\
\hline$\cdot / \cdot r$ & $\cdot / \pi r$ & $(\cdot / 19, \cdot / \pi Q, \cdot / \pi 1)$ & 9 & كارايى و اثربخشى & \\
\hline$\cdot / \cdot r$ & $\cdot / r 1$ & $(\cdot / r r \cdot \cdot / 19 \cdot \cdot / r \cdot)$ & 1. & حاكميت قانون & \\
\hline$/ . r$ & $\cdot / 4$ & $(\cdot / 4), \cdot / 44, \cdot / 44)$ & 1 & دسترسى به اطلاعات عمومى & \multirow{10}{*}{ شكئ تدوين و } \\
\hline$\cdot / r$ & $\cdot / \wedge 9$ & $(\cdot / 1 \cdot, \cdot / 9), \cdot / 99)$ & r & تو توافق عمومى & \\
\hline$\cdot / r$ & 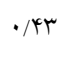 & 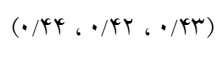 & r & شفافيت & \\
\hline$\% r$ & $\cdot /$ & $(\cdot / 1 \cdot, \cdot / 11, \cdot / 1 \cdot)$ & $r$ & رسيدگى و جبران & \\
\hline$\cdot / r$ & $\cdot / \wedge \mid$ & $(\cdot / 9 r ، \cdot / M 1 ، \cdot / 9 r)$ & $\Delta$ & انصاف اجتماعى & \\
\hline$\%$ r & . /Ar & $(\cdot / 91, \cdot / 10, \cdot / 99)$ & 4 & برابرى اجتماعى & \\
\hline$\%$ & $\cdot / \wedge 9$ & $(\cdot / V) \cdot \cdot / 90, \cdot / 9 T)$ & v & مسئوليت بذيرى & \\
\hline$\% r$ & $\cdot / \wedge r$ & $(\cdot / 91 ، \cdot / 19, \cdot \cdot / 91)$ & $\wedge$ & يَاسخگُويى & \\
\hline.$/ r$ & $\cdot \pi$ & $(\cdot / r), \cdot / 1 \wedge, \cdot / r \cdot)$ & 9 & كارايى و اثربخشى & \\
\hline.$/ 4$ & $\cdot / 9$ & $(\cdot / r \Delta, \cdot / 9 \mu, \cdot \cdot / \Lambda 1)$ & 1. & حاكميت قانون & \\
\hline
\end{tabular}


ادامه جدول r ا: ديد

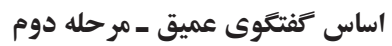

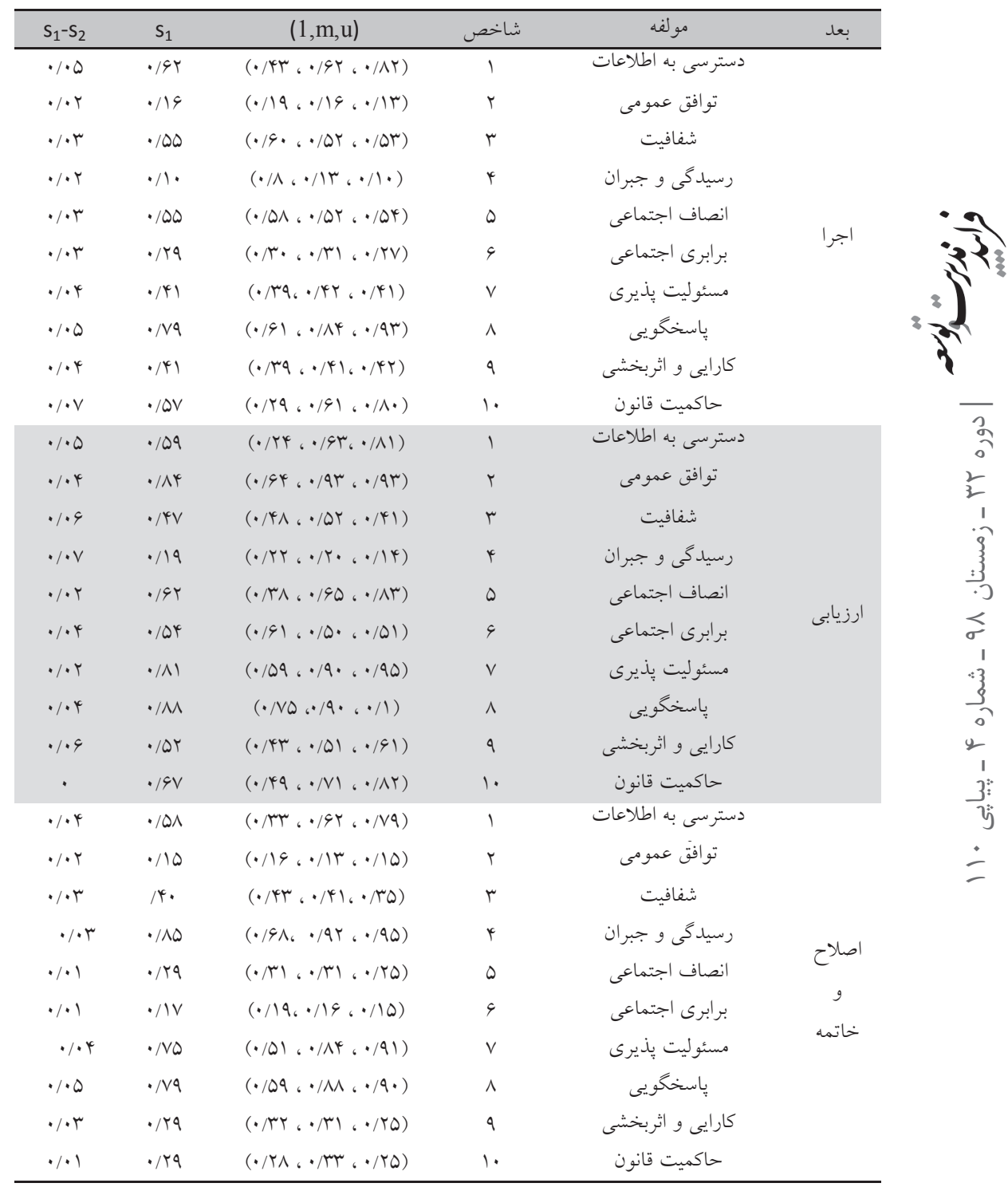


جدول با ا: ديدكاه خبر كان در خصوص خدمات عمومى در جرخه خطمشى گذارى بر اساس شراكتهاى كارى ـ مرحله دوم خدمان

\begin{tabular}{|c|c|c|c|c|c|}
\hline $\mathrm{S}_{1}-\mathrm{S}_{2}$ & $\mathrm{~s}_{1}$ & $(1, \mathrm{~m}, \mathrm{u})$ & شاخص & مولفه & بعد \\
\hline.$/ .4$ & $\cdot / r$ & $(\cdot / r \Delta, \cdot / r, \cdot(\pi))$ & 1 & دسترسى به اطلاعات عمومى & \multirow{10}{*}{ ش شناسايى } \\
\hline$\cdot / 1$ & $\cdot \pi r$ & $(\cdot / r \Delta, \cdot / r, \cdot / r r)$ & r & توافق عمومى & \\
\hline.$/ .0$ & $\cdot / r)$ & $(\cdot / \pi r, \cdot 10, \cdot / 19)$ & r & شفافيت & \\
\hline$/ . r$ & .110 & $(\cdot / 1 \mathrm{r}, \cdot / 10, \cdot / 1 \Lambda)$ & $\varphi$ & رسيدگى و جبران & \\
\hline$\cdot / \cdot 0$ & $\cdot / \pi$ & $(\cdot / r \Delta, \cdot / r \mu, \cdot / r \cdot)$ & 0 & انصاف اجتماعى & \\
\hline.$/ \cdot 1$ & .190 & $\left(\cdot / r \Delta, \cdot / N \sigma_{0} \cdot / \Lambda q\right)$ & 9 & برابرى اجتماعى & \\
\hline$\cdot / \cdot r$ & .191 & $(\cdot / 49 ، \cdot 199 ، \cdot 1 / 49)$ & v & مسئوليت يذيرى & \\
\hline$\cdot / r$ & $\cdot / r$ & $(\cdot / \pi, \cdot / \pi \cdot \cdot \pi \Delta)$ & $\wedge$ & ياسخگَويى & \\
\hline.$/ \cdot 1$ & $\cdot / / V$ & $(\cdot / \pi / \cdot / 9 ، \cdot / / \Lambda)$ & 9 & كارايى و اثربخشى & \\
\hline .1 .4 & $\cdot / 4$ & $(\cdot / \Delta 1, \cdot / \uparrow \Delta, \cdot / r \Delta)$ & 1. & حاكميت قانون & \\
\hline . & .119 & $(\cdot / r \cdot, \cdot / / r, \cdot / / \psi)$ & 1 & دسترسى به اطلاعات عمومى & \multirow{10}{*}{ كار } \\
\hline.$/ 1$ & $\cdot \pi r$ & $(\cdot / r Q, \cdot / r r \cdot \cdot / l \cdot)$ & r & تو افق عمومى & \\
\hline.$/ 4$ & $\cdot / \mu 1$ & $(\cdot / 19 ، \cdot / r r, \cdot / 4 r)$ & r & شفافيت & \\
\hline.$/ \cdot 1$ & $\cdot / T^{4}$ & $(\cdot / \pi r, \cdot / 19, \cdot / \pi 9)$ & r & رسيدگى و جبران & \\
\hline$\cdot / \cdot \wedge$ & $\cdot / T V$ & $(\cdot / r q, \cdot / r r \cdot(\cdot / 4))$ & 0 & انصاف اجتماعى & \\
\hline$\cdot / \cdot 1$ & 每 & $(\cdot / r q, \cdot / 4 r, \cdot / r 1)$ & 4 & برابرى اجتماعى & \\
\hline 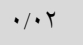 &.$/ 94$ & $\left(\cdot / T_{6} \cdot \cdot N I \cdot \cdot / N Y\right)$ & v & مسئوليت يذيرى & \\
\hline.$/ 1$ &.$/ 9 \mathrm{~V}$ & $\left(\cdot / 4 q_{6} \cdot / N r \cdot \cdot / v q\right)$ & $\wedge$ & ياسخكُويى & \\
\hline.$/ \cdot 1$ &.$/ 10$ & $(\cdot / 1 \wedge, \cdot / / \Gamma, \cdot / / Q)$ & 9 & كارايى و اثربخشى & \\
\hline.$/ .0$ & $\cdot / T \Lambda$ & $(\cdot / \Gamma \Lambda, \cdot / \pi r \cdot \cdot / T V)$ & 1. & حاكميت قانون & \\
\hline.$/ .1$ & $\cdot$ ra & $\left(\cdot / \mu_{1} \cdot / \mu_{6} \cdot / \mu_{1}\right)$ & 1 & دسترسى به اطلاعات عمومى & \multirow{10}{*}{ تدوين و } \\
\hline$\cdot / \cdot r$ & . Ar & $(\cdot / 4), \cdot / 4), \cdot / * \Delta)$ & r & توافق عمومى & \\
\hline$/ . r$ & $\cdot / r$ & $\left(\cdot / \pi r_{6} \cdot / r q ، \cdot / r q\right)$ & r & شفافيت & \\
\hline.$/ .0$ & $\cdot / / V$ & $(\cdot / r r, \cdot / 10, \cdot / / r)$ & $\varphi$ & رسيدگى و جبران & \\
\hline.$/ T$ & $\cdot / 44$ & $\left(\cdot / \Delta \sigma_{6} \cdot / 44, \cdot / T\right)$ & 0 & انصاف اجتماعى & \\
\hline 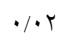 &.$/ 01$ & $\left(\cdot / \Delta \cdot, \cdot / \Delta \varphi^{+}, \cdot / 4 \Lambda\right)$ & 9 & برابرى اجتماعى & \\
\hline .1 .4 & .194 & $(\cdot / 99 ، \cdot 194 ، \cdot / 9 r)$ & $v$ & مسئوليت بذيرى & \\
\hline . & .194 & $(\cdot / 44, \cdot / 99, \cdot / 19)$ & $\wedge$ & ي پِاسخكويى & \\
\hline$/ . r$ &.$/ 14$ & $(\cdot / 1 \wedge, \cdot / 1 \cdot, \cdot / / 4)$ & 9 & كارايى و اثربخشى & \\
\hline.$/ 11$ & $\cdot 109$ & $(\cdot / 9 \Lambda, \cdot / \Delta 0, \cdot / 4 \Delta)$ & 1. & حاكميت قانون & \\
\hline
\end{tabular}


ادامه جدول سا: ديد كاه خبر كان در خصوص خدمات عمومى در جرخه خطمشى كذارى بر اساس شراكتهاى كارى - مرحله دوم خدمات عموم دور

\begin{tabular}{|c|c|c|c|c|c|}
\hline $\mathrm{s}_{1}-\mathrm{s}_{2}$ & $\mathrm{~S}_{1}$ & $(1, \mathrm{~m}, \mathrm{u})$ & شاخص & مولفه & بعد \\
\hline.$/ \cdot 7$ & $\cdot / \varepsilon$ & $(\cdot / \Sigma 7 ، \cdot / \varepsilon r, \cdot / \Gamma T)$ & 1 & دسترسى به اطلاعات عمومى & \multirow{10}{*}{ اجرا } \\
\hline$\cdot / \cdot r$ & $\cdot / r$ & $(\bullet / / \varepsilon, \cdot / T r, \bullet / T r)$ & r & تو افق عمومى & \\
\hline.$/ \cdot t$ & $\cdot / T V$ & $\left(\cdot / r q, \cdot / r 0_{6} \cdot / T V\right)$ & r & شفافيت & \\
\hline$\cdot / \cdot \wedge$ & $\cdot / r 7$ & $(\cdot / r 0, \cdot / r 9, \cdot / r 0)$ & $\varepsilon$ & رسيدگى و جبران & \\
\hline$\cdot / 0 \varepsilon$ & $\cdot / \pi \varepsilon$ & $(\cdot / r 0 ، \cdot / \varepsilon, \cdot / \pi)$ & ० & انصاف اجتماعى & \\
\hline$\cdot / \cdot r$ & $\cdot / A r$ & $(\cdot / 7 \cdot . \cdot / 906 \cdot / 9)$ & 7 & برابرى اجتماعى & \\
\hline$\cdot / \cdot 1$ & $\cdot / 9$ & $(\cdot / 10, \cdot / 9 \cdot, \cdot / 90)$ & v & مسئوليت بذيرى & \\
\hline$\cdot / \cdot 9$ & $\cdot / V$ & $(\cdot / \varepsilon r, \cdot / \varepsilon) \cdot \cdot / \Lambda \Lambda)$ & $\wedge$ & ياسخخويى & \\
\hline$\cdot / \cdot r$ & $\cdot / V_{0}$ & $(\cdot / 00 ، \cdot / 1 \cdot . \cdot / 91)$ & 9 & كارايى و اثربخشى & \\
\hline$\cdot / \cdot 1$ & $\cdot / 0 \mathrm{~V}$ & $(\cdot / 70, \cdot / 0 r \cdot \cdot / 0 r)$ & 1. & حاكميت قانون & \\
\hline$\cdot / 11$ & $\cdot / 20$ & $(\cdot / 07, \cdot / 20, \cdot / / 0)$ & 1 & دسترسى به اطلاعات عمومى & \multirow{10}{*}{ 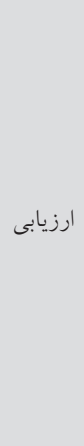 } \\
\hline$\cdot / \cdot \wedge$ & $\cdot / \varepsilon$ & $\left(\cdot / \Gamma_{0} \cdot \cdot / \mu_{a} \cdot / \varepsilon 7\right)$ & r & 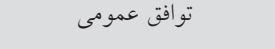 & \\
\hline$\cdot / \cdot \wedge$ & $\cdot / \mu 1$ & $\left(\cdot / \Gamma_{0} \cdot \cdot / q, \cdot / T \Lambda\right)$ & r & شفافيت & \\
\hline$\cdot / \cdot \varepsilon$ & $\cdot / r 7$ & $(\cdot / r q ، \cdot / r q, \cdot / r \varepsilon)$ & $\varepsilon$ & رسيدگى و جبران & \\
\hline$\cdot / \cdot \varepsilon$ & $\cdot / 7 r$ & $(\cdot / 7 r ، \cdot / 09, \cdot / 7 \varepsilon)$ & 0 & انصاف اجتماعى & \\
\hline$\cdot / \cdot 0$ & $\cdot / N r$ & $(\cdot / 07 ، \cdot / 20, \cdot / 117)$ & 7 & برابرى اجتماعى & \\
\hline$\cdot / \cdot v$ & $\cdot / 0$ & $(\cdot / \varepsilon \wedge, \cdot / 0 r, \cdot / 0 \cdot)$ & v & مسئوليت يذيرى & \\
\hline$\cdot / \cdot 1$ & $\cdot / v \wedge$ & $(\cdot / 7 r, \cdot / V \varepsilon, \cdot / 90)$ & $\wedge$ & ياسخكويى & \\
\hline$\cdot / \cdot v$ & $\cdot / 70$ & $(\cdot / N 1, \cdot / 01, \cdot / 70)$ & 9 & كارايى و اثربخشى & \\
\hline$\cdot / \cdot 1$ & 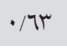 & $(\cdot / 09 ، \cdot / 79 \cdot \cdot / 71)$ & 1. & حاكميت قانون & \\
\hline$\cdot / 11$ & $\cdot / 20$ & $(\cdot / 0 r, \cdot / 20, \cdot / r q)$ & 1 & \multirow{2}{*}{ دسترسى به اطلاعات عمومى } & \multirow{10}{*}{ خاتمه } \\
\hline$\cdot / 11$ & $\cdot / \pi 9$ & $(\cdot / \Gamma 0, \cdot / r 7, \cdot / r 0)$ & r & & \\
\hline$\cdot / 1$ & $\cdot / T \Lambda$ & $(\cdot / 21, \cdot / 10, \cdot / 19)$ & r & شفافيت & \\
\hline.$/ \cdot r$ & $\cdot / 71$ & $\left(\cdot / 2 r^{\prime} \cdot / / V 0, \cdot / 70\right)$ & $\varepsilon$ & رسيدگى و جبران & \\
\hline$\cdot / \cdot \wedge$ & $\cdot / \mu \Lambda$ & $(\cdot / \% 0, \cdot / 20, \cdot / \Gamma 0)$ & 0 & انصاف اجتماعى & \\
\hline .1 .0 & $\cdot / \mu V$ & $(\cdot / r 7, \cdot / r 7, \cdot / r q)$ & 7 & برابرى اجتماعى & \\
\hline$\cdot / \cdot 0$ & $\cdot 10$ & $(\cdot / 29, \cdot / 2 \Lambda, \cdot / 0 r)$ & V & مسئوليت يذيرى & \\
\hline$\cdot / \cdot 1$ & $\cdot / 01$ & $(\cdot / 77, \cdot / 9 \cdot, \cdot / 1)$ & $\wedge$ & ياسخگگ يَى & \\
\hline$\cdot / 10$ & $\cdot / T V$ & $\left(\cdot / \varepsilon r, \cdot / r r^{\prime} \cdot / / 0\right)$ & 9 & كارايى و اثربخشى & \\
\hline$\cdot / T \varepsilon$ & $\cdot / \varepsilon r$ & $(\cdot / r V ، \cdot / 70 ، \cdot / T)$ & 1. & حاكميت قانون & \\
\hline
\end{tabular}


بر اساس ديدكاه عنوانشده در مرحله اول و قياس آن با خروجى مرحله دوم بر اساس فرمول

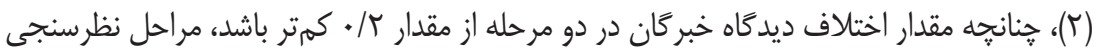

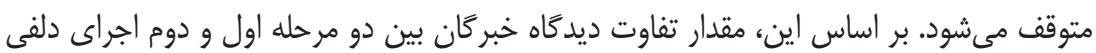

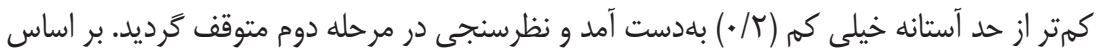

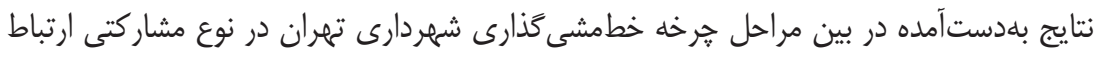

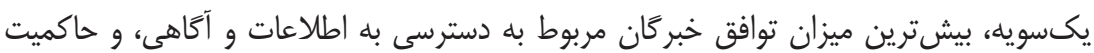
قانون در مرحله شناسايى و درك مشكل؛ شفافيت، مسئوليتيذيرى، و پاسخخكويى در مرحله

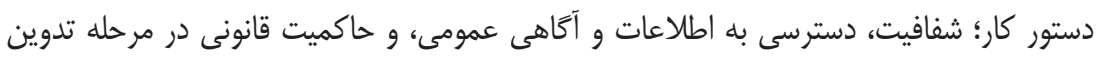

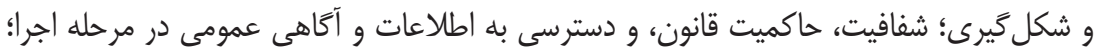

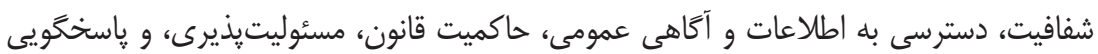

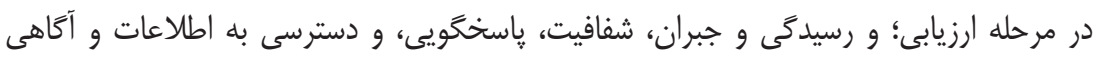
عمومى در مرحله اصلاح و خاتمه است.

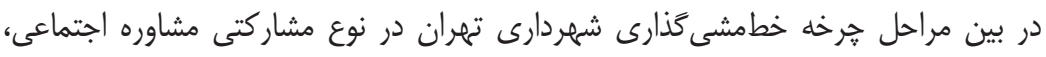

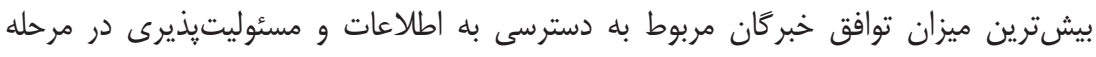

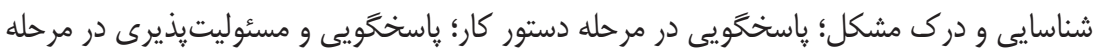

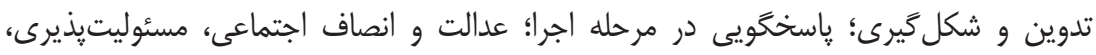

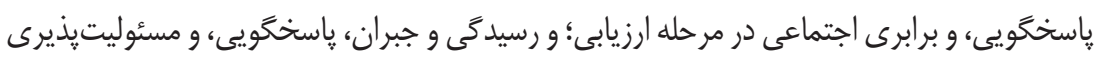
در مرحله اصلاح و خاتمه است.

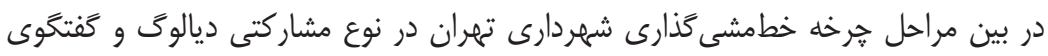

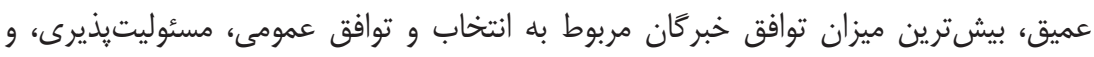

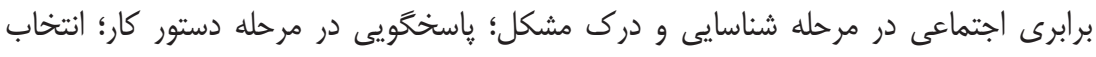

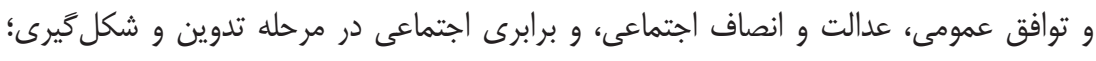

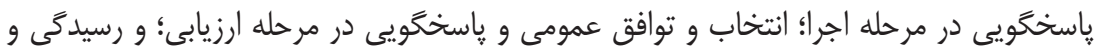
جبران، پاسخكويى، و مسئوليتيذيرى در مرحله اصلاح و خاتمه است.

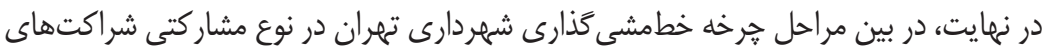

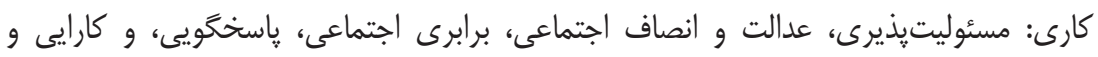
اثربخشى در مرحله اجرا؛ ياسخكويى در مرحله ارزيابى و مرحله اصلاح و خاتمه است. 


\section{اعتبارسنجى مدل}

״س از دستيابى به نتايج تكنيك دلفى فازى، با هدف اعتباريابى، از شاخص جذر ميانگين

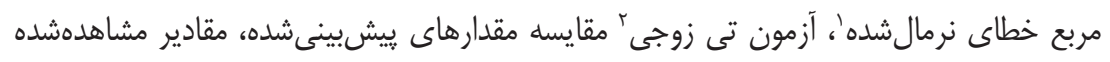

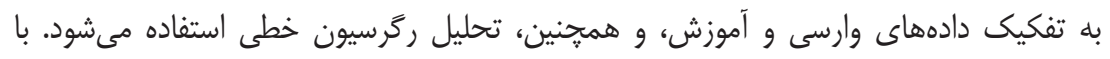

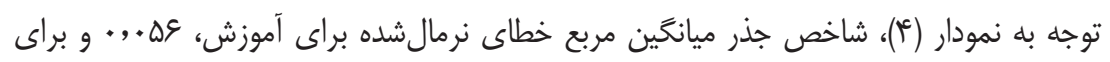

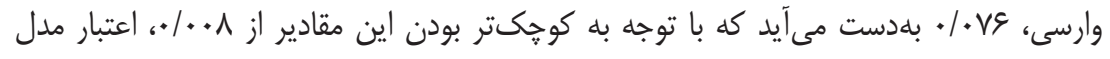

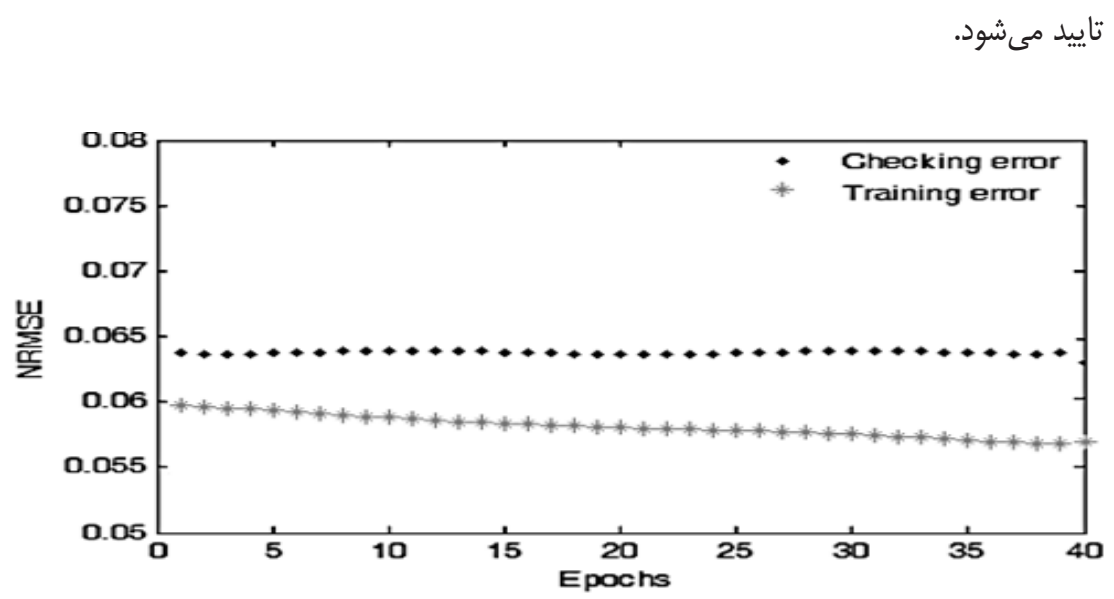
نمودار †:: جذر ميانعين مربع خطاى نرمالشده

همجنين در روشى ديگر از اعتبارسنجى، دادههاى مربوط به مولفههاى خدمات عمومى نوين و فرايند خطمشى گذارى به عنوان متغيرهاى مستقل وارد مدل مى شود و خروجى سيستم به عنوان دادههاى ييشبينىشده انفيس، با مقدارهاى تجربى مشاركت شهروندى مقايسه مىشود. برابرى دادههاى ييشبينىشده دادههاى آزمون با دادههاى مشاهدهشده آنها مىتواند نشانخر اعتبار مدل باشد. نمودار (ه)، دادههاى ييشبينى و مشاهدهشده را براى هـ داده وارسى و آزمون نشان مى دههد.

1. Normalized Root Mean Square Error

2. Paired Sample T Test 


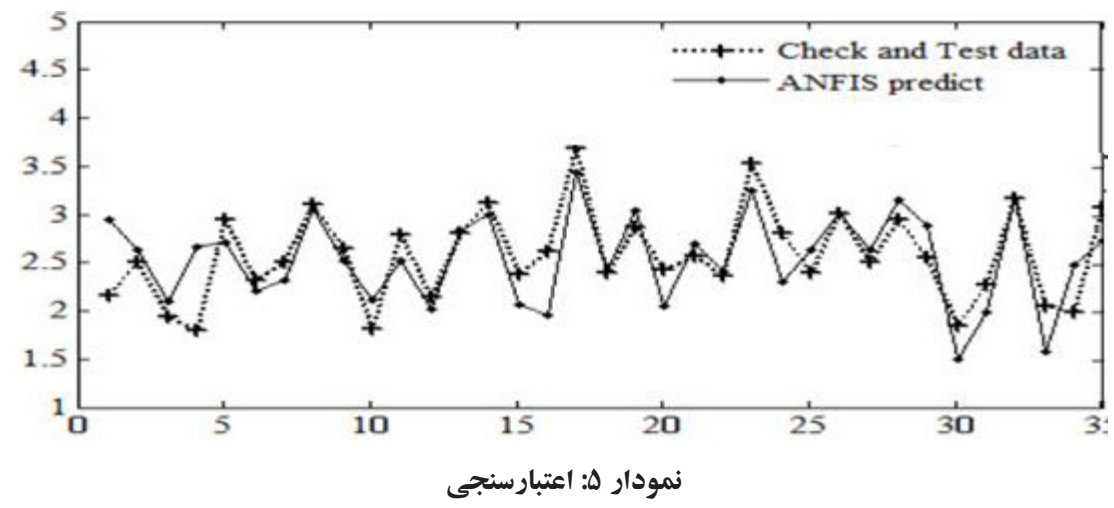

بر پايه خروجى آزمون تى، به منظور قياس دادههاى يِيشينىشده و مشاهدهشده براى

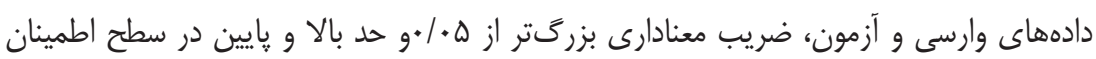

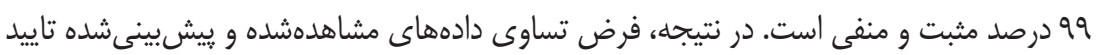
مى شود.

\section{مدلسازى و بيشينهسازى}

يس از تاييد اعتبار الكَو، جهار نوع مشاركت توسط سيسته استتناج فازى' بر اساس • عب قانون توسط نرمافزار متلب مورد مدلسازى و بيشينهسازى قرار مى گيرد. در مشاركت نوع اول، اركان

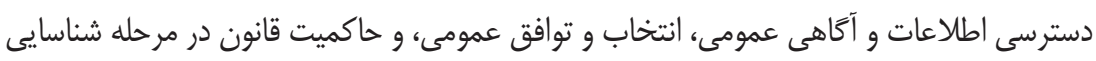
و درك مشكل؛ شفافيت، رسيدگى و جبران، و مسئوليتيذرى در مرحله دستور كار؛ دسترسى به

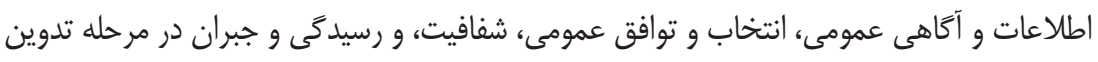

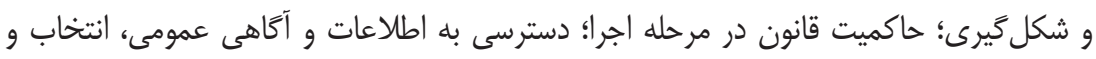

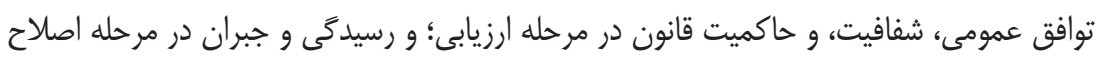
و خاتمه داراى بيشترين` حضور هستند.

1. Fuzzy Inference System

2. Max 


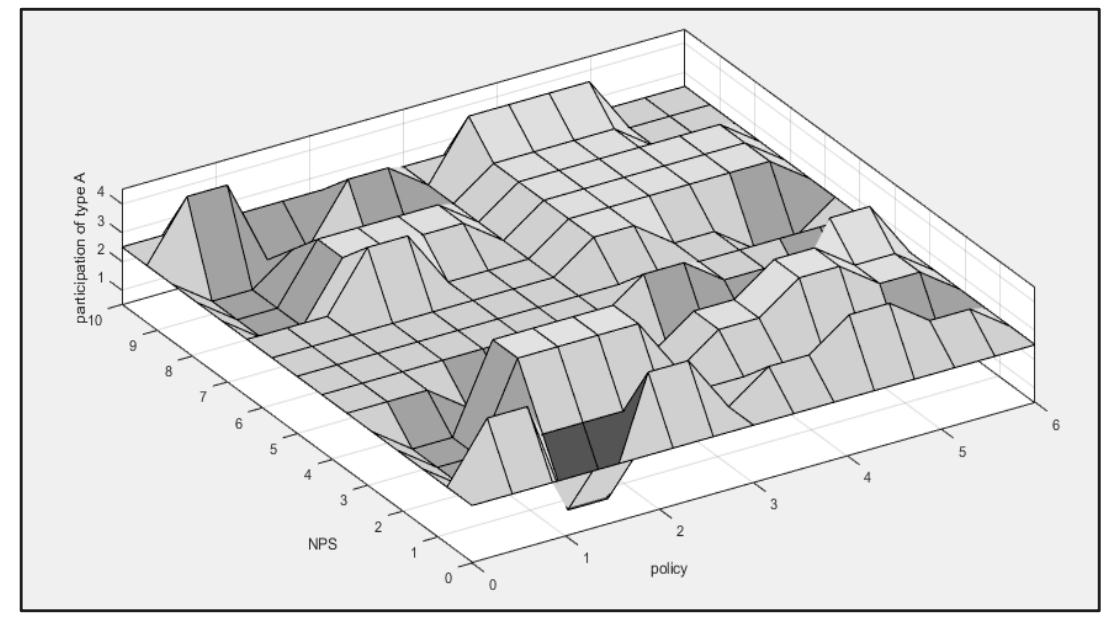

نمودار و: ديد كاه سرفيس' مشاركت نوع اول- ارتباط يكسويه

در مشاركت نوع دوم، دسترسى به اطلاعات و آكاهى عمومى در مرحله شناسايى و درى

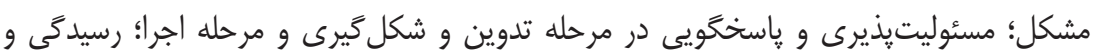
جبران، برابرى اجتماعى، مسئوليتيذيرى، و پاسخگَيى در مرحله ارزيابى؛ و رسيدگى و جبران، مسئوليتيذيرى، و ياسخكويى در مرحله اصلاح و خاتمه داراى بيشترين حضور هستند.

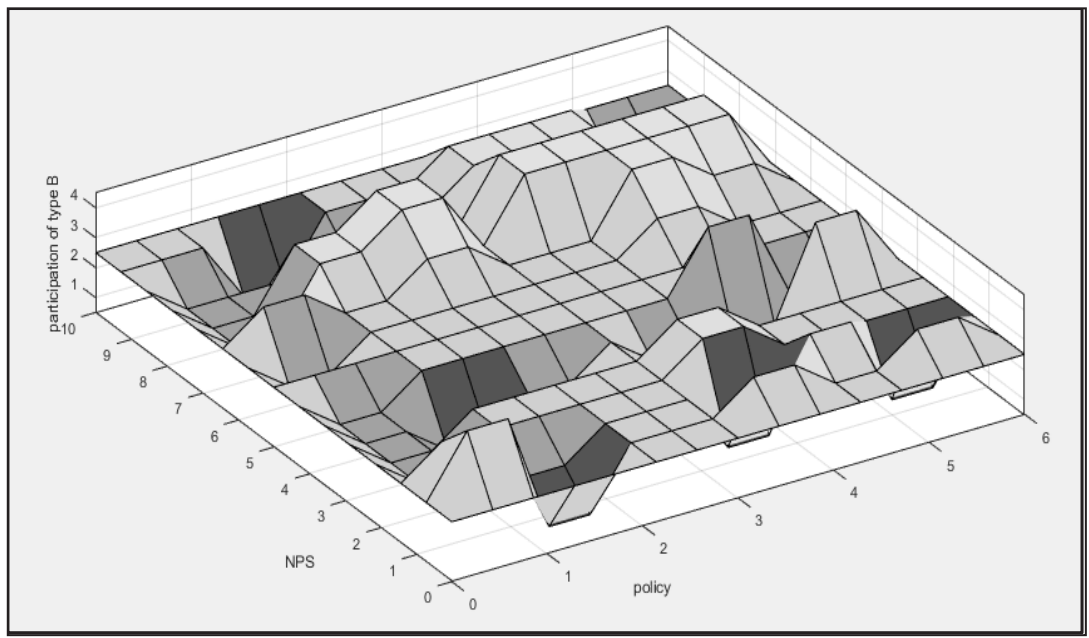

कर

نمودار Y: ديد كاه سرفيس مشاركت نوع دوم - مشاوره اجتماعى

1. Surface View 
در مشاركت نوع سوم، دسترسى به اطلاعات و آَاهى عمومى، انتخاب و توافق عمومى، مسئوليتيذيرى در مرحله شناسايى و درك مشكل؛ ياسخگُويى، و كارايى و اثربخشى در مرحله

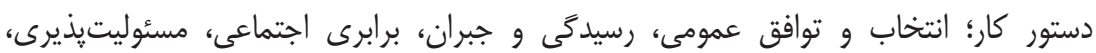

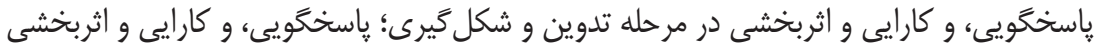
در مرحله اجرا؛ انتخاب و توافق عمومى، ياسخكَويى، و كارايى و اثربخشى در مرحله ارزيابى؛ و و رسيدگى و جبران، ياسخَّويى، و كارايى و اثربخشى در مرحله اصلاح و خاتمه بيشترين حضور

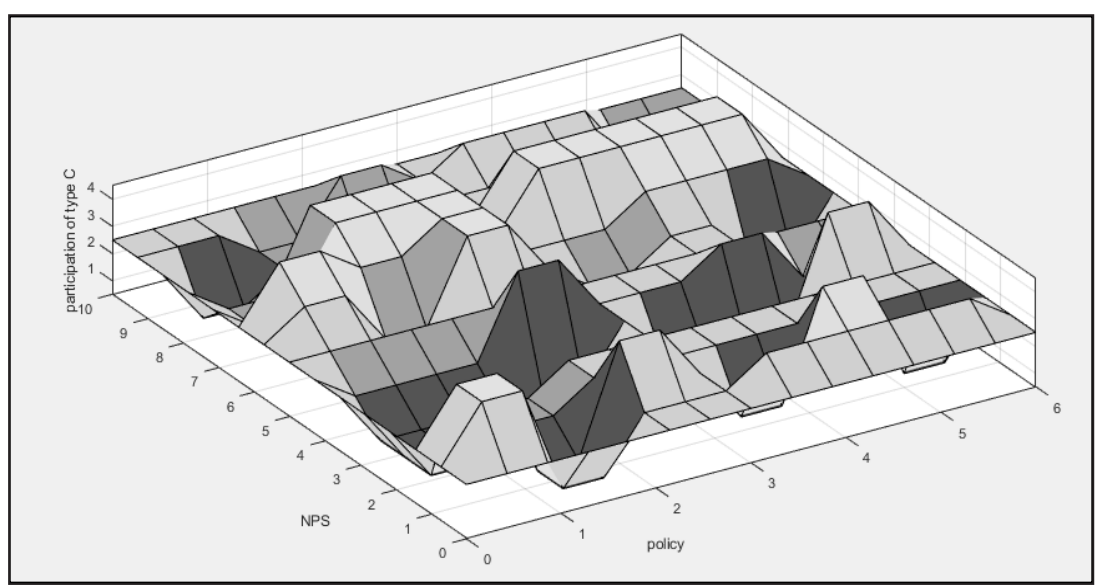

نمودار ه: ديدكاه سرفيس مشار كت نوع سوم - ديالوكى و كفتگوى عميق

در مشاركت نوع جهارم، عدالت و انصاف اجتماعى، برابرى اجتماعى، و مسئوليتيذيرى در مرحله تدوين و شكل گيرى؛ عدالت و انصاف اجتماعى، برابرى اجتماعى، و مسئوليتيذيرى درى مرحله اجرا؛ ياسخَّويى، و كارايى و اثربخشى در مرحله اصلاح و خاتمه داراى بيشترين حضور 


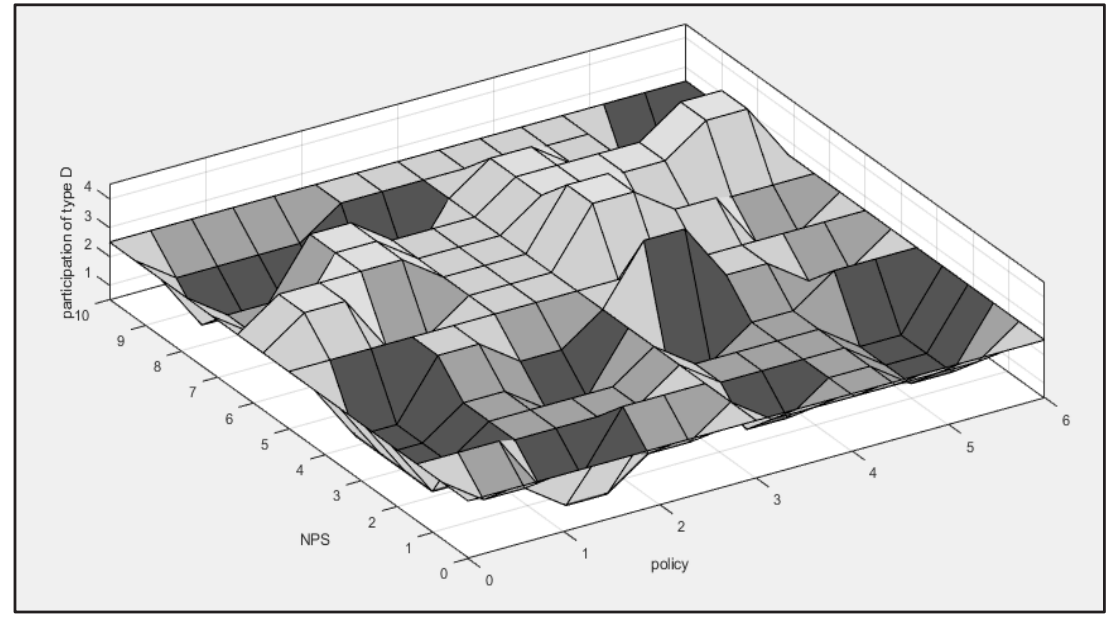

نمودار q: ديد كاه سرفيس مشار كت نوع جهارم - شراكت كارى

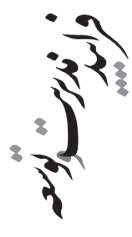

\section{ترسيم وضع موجود شهردارى تهر ان بر اساس التوى تاييدشده}

مقايسه ميانگين وضع موجود با ميانگين وضع مطلوب مشاركت نوع اول در شهردارى تهران:

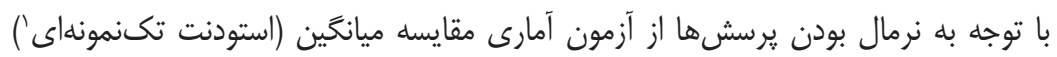

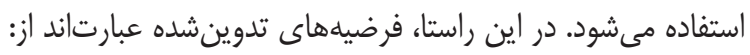
: بيانگر نبود تفاوت ميانگَين يرسشهاى ارتباطات يكسويه و ميانخين در نظرگرفتهشده.

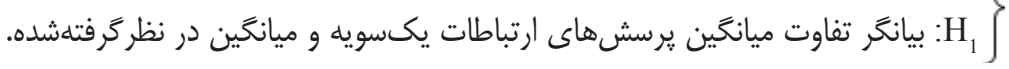




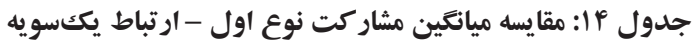

$$
\text { ميانخين مفروض }
$$

\begin{tabular}{|c|c|c|c|c|c|c|c|}
\hline \multicolumn{8}{|c|}{ 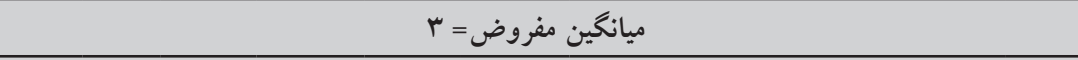 } \\
\hline \multicolumn{2}{|c|}{ فاصله اطمينان } & \multirow{2}{*}{ تفاوت } & \multirow{2}{*}{ معنادارى } & \multirow{2}{*}{ درآز } & \multirow[t]{2}{*}{ استيودنت } & \multirow{2}{*}{ يرس ها } & \multirow{2}{*}{ رديف } \\
\hline بالا & يايين & & & & & & \\
\hline · & W & سו/ & .1 .9 & ऍ人. & • & ارتباط بين "دسترسى به اطلاعات و آكاهى & 1 \\
\hline $1 / 4 q$ & $1 / r$ & $1 / r q 4$ & - & ґ^. & $r V / \cdot \Delta q$ & ارتباط بين (انتخاب و توافق عمومى)" و & r \\
\hline$\cdot / \pi q$ & $\cdot 1 \cdot 0$ & $\cdot /|V|$ & $\cdot 1 \cdot+x$ & ros & Y/AV & ارتباط بين "حاكميت قانون)" و (شناسايى & r \\
\hline$-\cdot 109$ & $-\cdot / \wedge \mid$ & -.1911 & . & req & $-1 \cdot 194 \wedge$ & ارتباط بين (شفافيت)) و (دستور كار)" & c \\
\hline . & $\cdot 1 \cdot 0$ & $\cdot / 19 \mathrm{~V}$ & $.1 \cdot 11$ & ra. & $T / D V$ & ارتباط بين "(رسيدگى و جبران)" & $\Delta$ \\
\hline . / Y & $-\cdot 1 \cdot 9$ & $\cdot / \cdot \wedge r$ & - MYY & ren & l/IVT & ارتباط بين (مسئوليتيذيرى)" و ((دستور كار)" & 9 \\
\hline$-\cdot / \cdot 1$ & سח/•- & $-\cdot / r \cdot \Lambda$ & $\cdot 1 \cdots 1$ & rV. & $-r / r \mid \Lambda$ & آخاهى عمو مى ارتباط بين "(دسترسى به اطلاعات و & V \\
\hline$\cdot / T Q$ & $\cdot / 1$ & •/MI & תr. & TVT & T/ITV & ارتباط بين (انتخاب و توافق عمومى") و & $\wedge$ \\
\hline$-\cdot / 14$ & $-\cdot / 4$ & $-\cdot /$ Y A & - & 快. & $-1 / .90$ & ارتباط بين (شفافيت)" و (تاوين و & 9 \\
\hline$-\cdot / I V$ & $-\cdot /$ M & $-\cdot / \mu \cdot 1$ & - & rve & $-4 / 919$ & ارتباط بين (رسيدگى و جبران)) و ((تدوين & 1. \\
\hline .119 & $-\cdot \cdot \cdot 1$ & $\cdot / \cdot r V$ & - /DYD & rve & $\cdot 19 \cdot 0$ & در ارتباط بين (حاكميت قانون)) و ((اجرا)) & 11 \\
\hline$-\cdot / r$ & $-\cdot / Y^{\mathbb{Q} V}$ & צ & - & rᄉ. & $-Q / \cdot 1 \wedge$ & 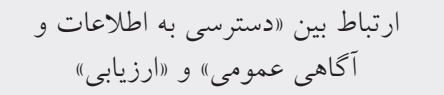 & Ir \\
\hline.$/ 01$ & $\cdot /$ TA & . rqu & • & rVA & $9 / 99 r$ & ارتباط بين "انتخاب و توافت عمومى"و & ir \\
\hline$-\cdot / 0$ & $-\cdot / V 9$ & $-.19 Y V$ & · & ror & $-9 / 491$ & $\begin{array}{l}\text { ارتباط بين (شفافيت) به عنوان مولفه عمومى نوين و (ارزيابى") }\end{array}$ & 14 \\
\hline$\cdot / 10$ & $-\cdot / 1$ & $\cdot / r \Delta$ & .1994 & reo & $\cdot /$ rqr & ارتباط بين (حاكميت قانون)) و (ارزيابى") & 10 \\
\hline$-\cdot / M_{Y}$ & $-\cdot 19$ &.$/ 499$ & · & roq & $-9 / 9 \wedge 9$ & ارتباط بين "رسيد گى و جبران)) و (اصلاح & 19 \\
\hline
\end{tabular}


با توجه به P-Value مىتوان با اطمينان هو درصد و سطح خطاى كوخكتر از ه./. عنوان

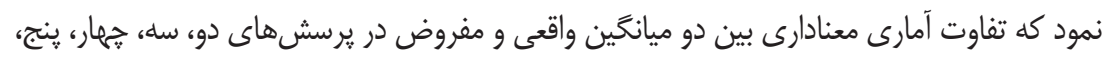

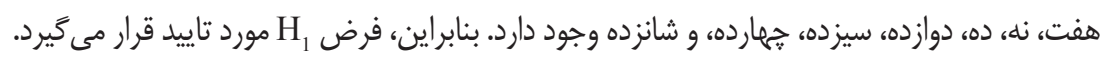

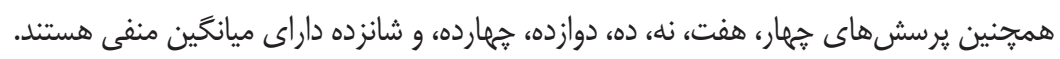

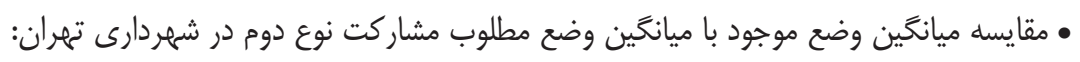

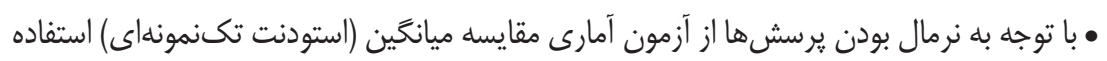

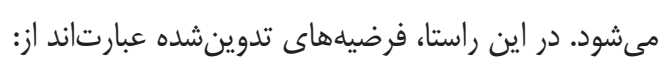

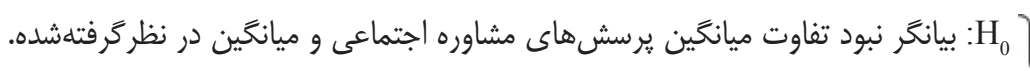

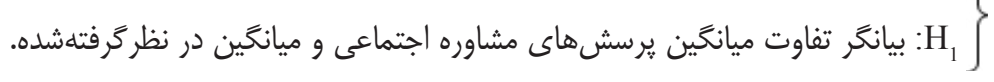

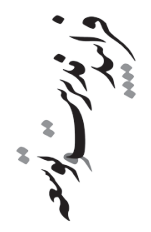

جدول ه ا: مقايسه ميانعَين مشار كت نوع دوم ـ مشاوره اجتماعى

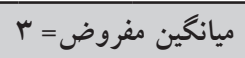

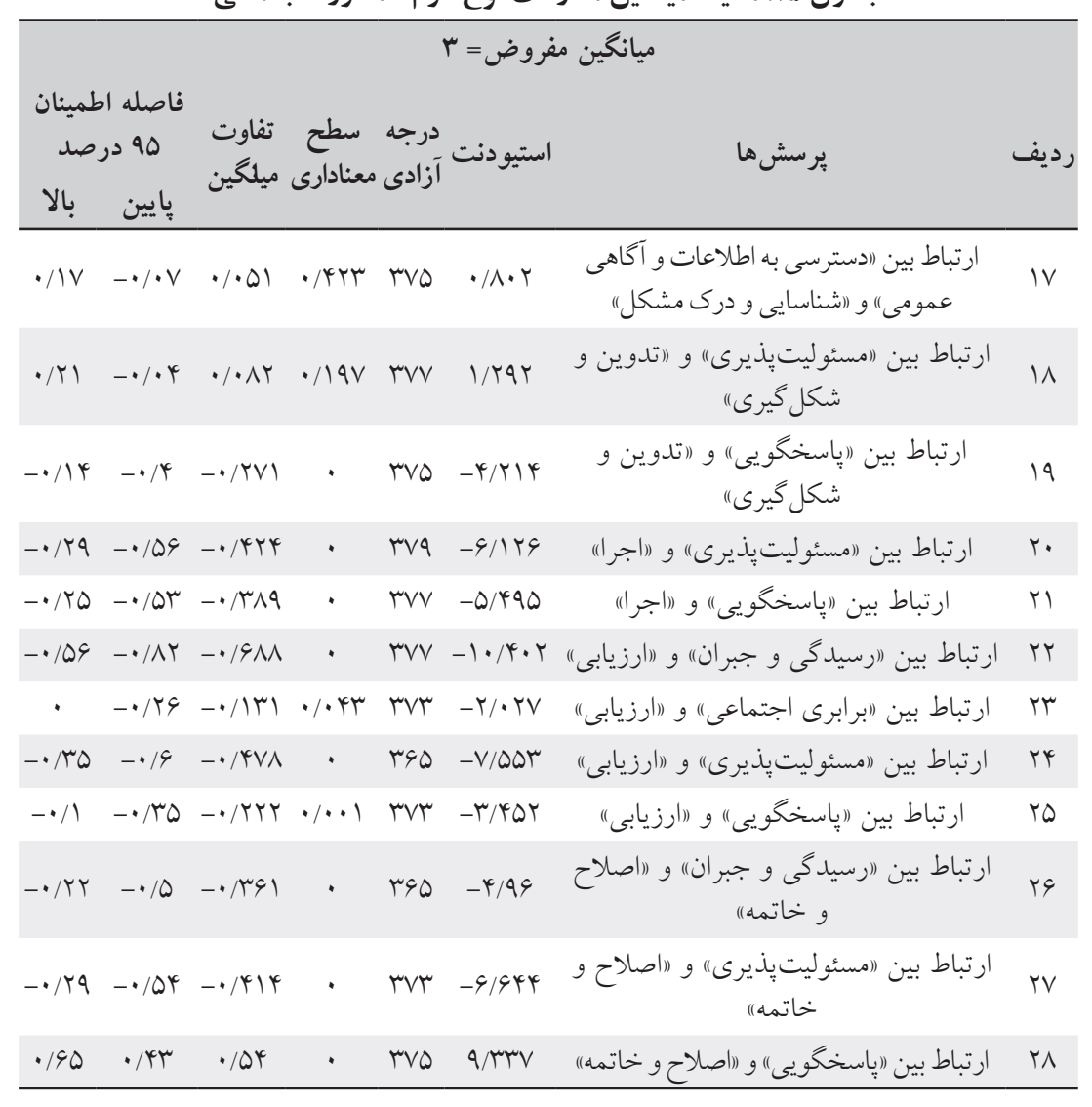


با توجه به P-Value مىتوان با اطمينان هو درصد و سطح خطاى كوجكتر از هـ/. عنوان

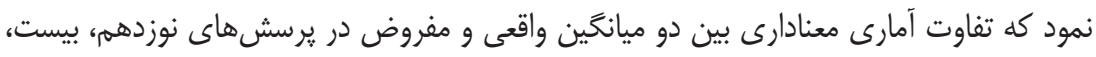

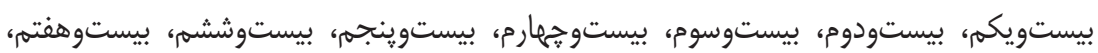

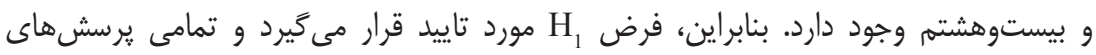
اشارهشه داراى ميانكين منفى هستند. مقايسه ميانكَين وضع موجود با ميانكين وضع مطلوب مشاركت نوع سوم در شهردارى تهران: با توجه به نرمال بودن يرسشها از آزمون آمارى مقايسه ميانكين (استودنت تكنمونهاى)

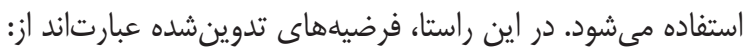

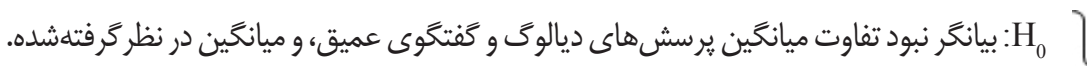

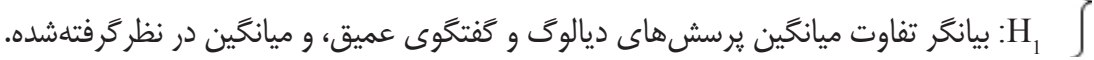


جدول 19: مقايسه ميانكين مشار كت نوع سوم ـ ديالوكى و كفتكوى عميق

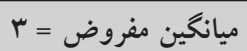

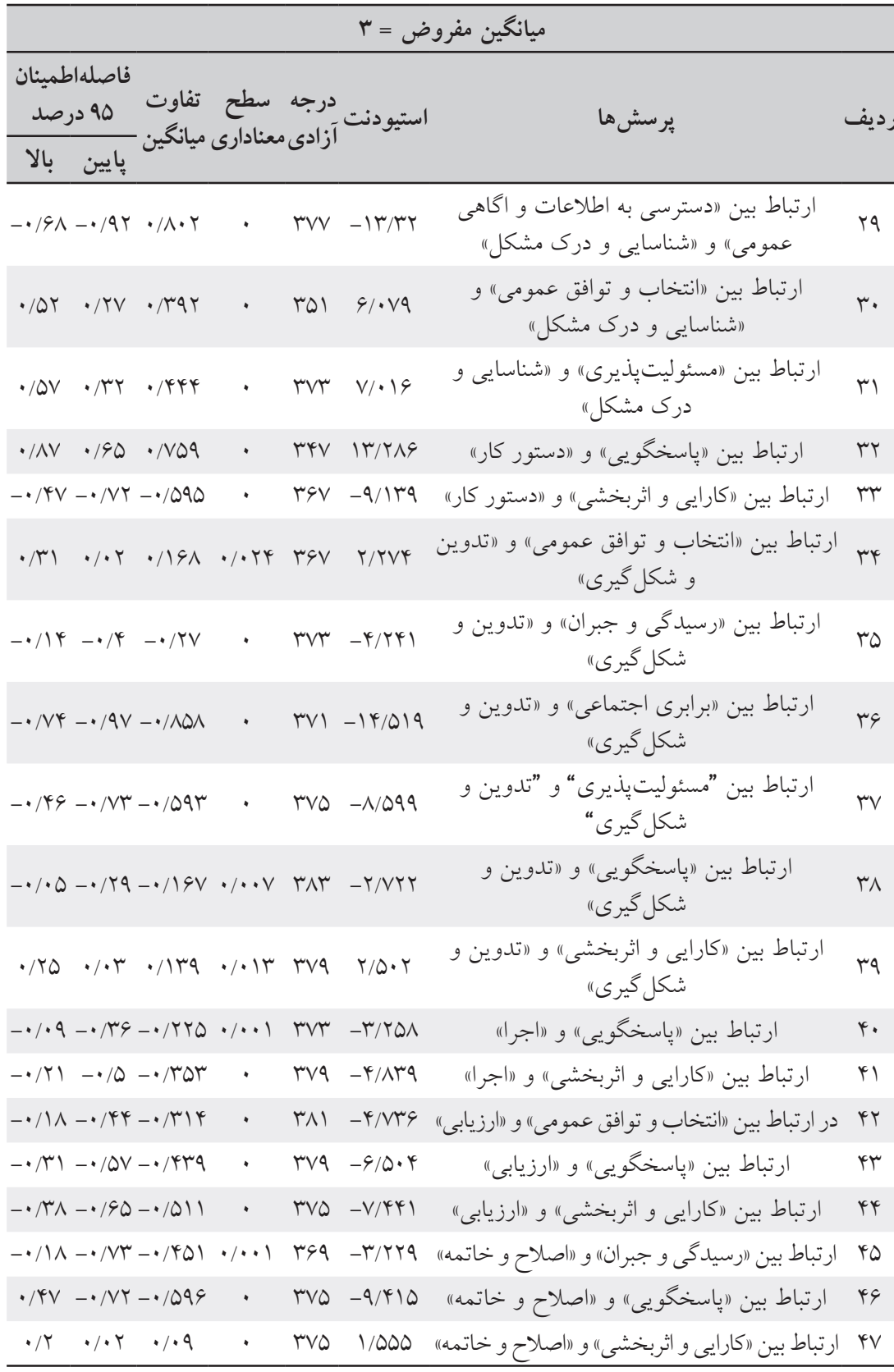


با توجه به P-Value مىتوان با اطمينان هو درصد و سطح خطاى كوجكتر از هـ/. عنوان

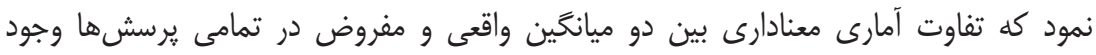
دارد. بنابراين فرض H

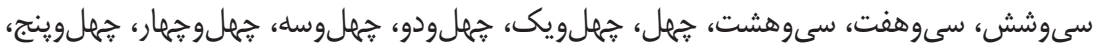
و هجلوشش داراى ميانخين منفى هستند.

مقايسه ميانكَين وضع موجود با ميانكين وضع مطلوب مشار كت نوع جهارم در شهردارى تهران:

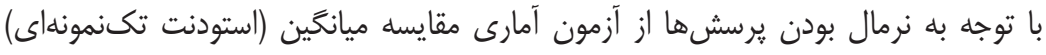

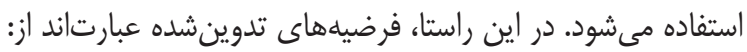

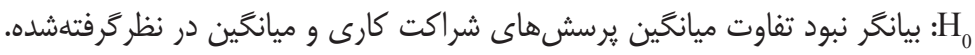

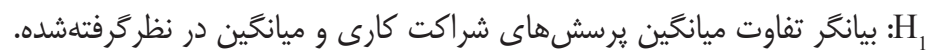

جدول YV: مقايسه ميانكين مشار كت نوع جهارم - شراكت كارى

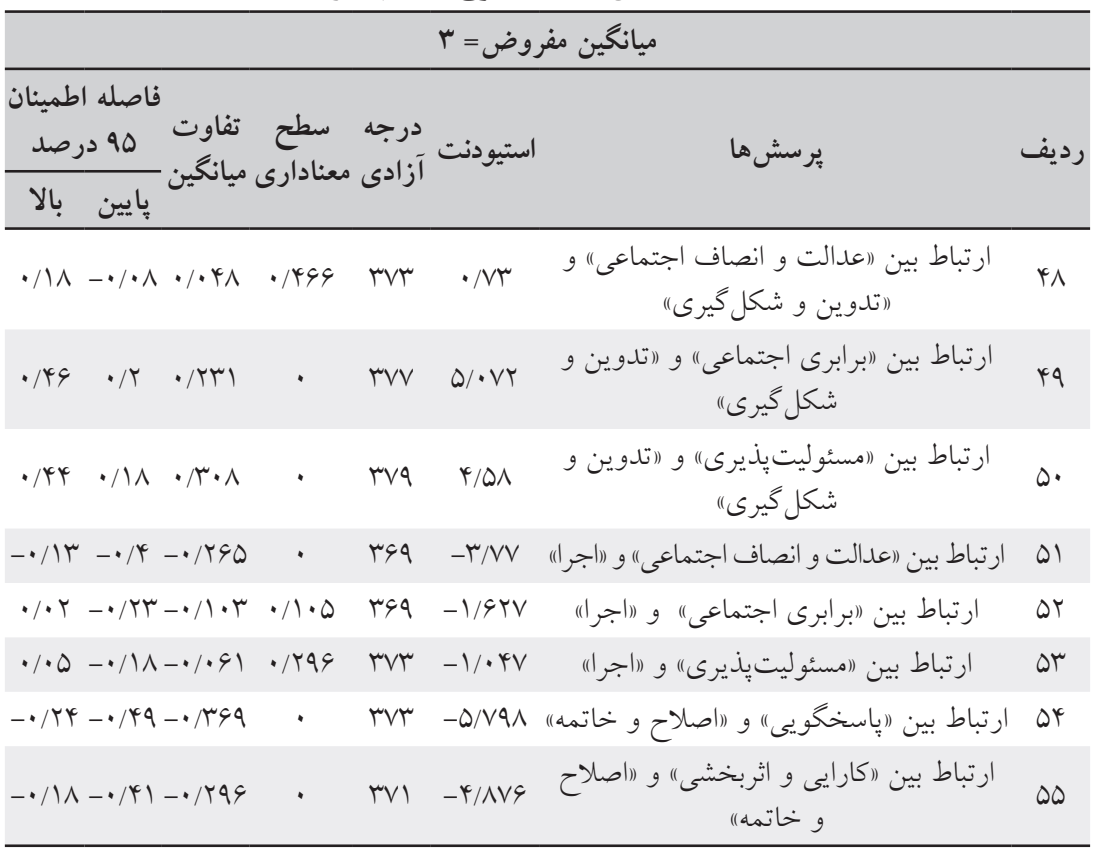

با توجه به P-Value مىتوان با اطمينان ه9 درصد و سطح خطاى كوخكتر از هـ/. عنوان نمود

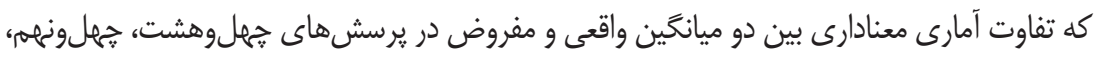




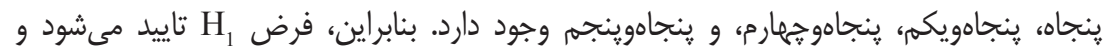

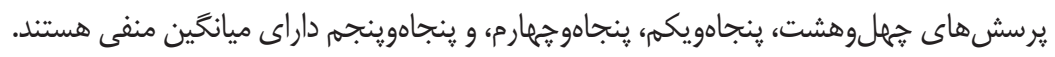

\section{بحث و نتيجه كيرى}

هدف يزوهش حاضر، معرفى يارادايم خدمات عمومى نوين و تاكيد بر نقش حياتى ابعاد خدمات

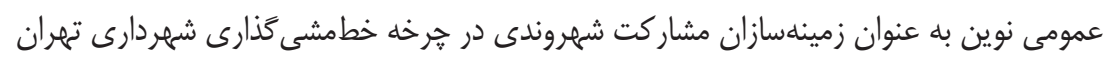

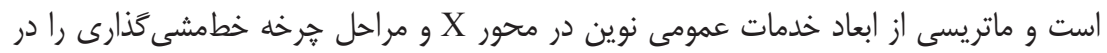

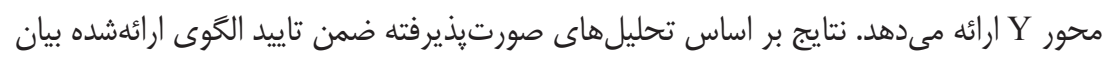

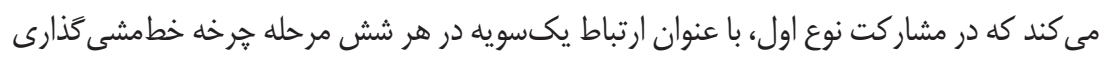

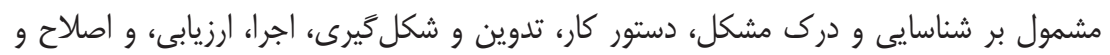

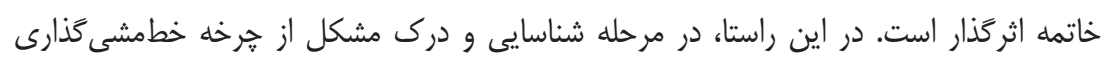

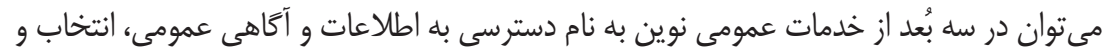

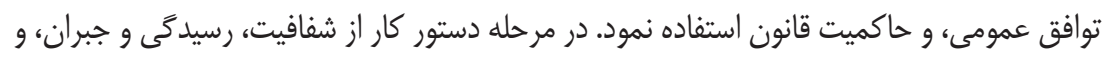
مسئوليتيذيرى؛ در مرحله تدوين و شكل گَيرى از دسترسى به اطلاعات و آكاهى عمومى، انتخاب

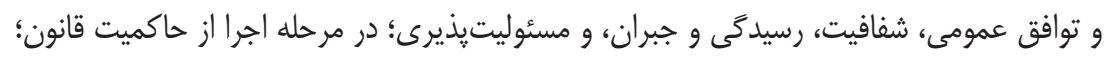

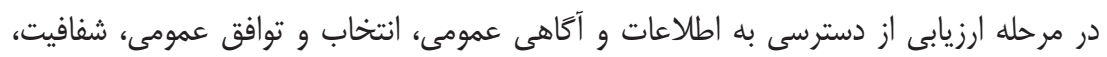

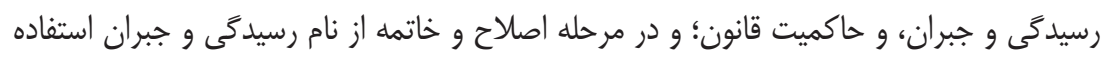

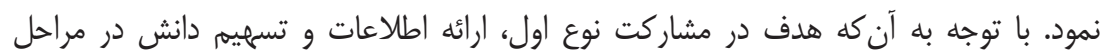

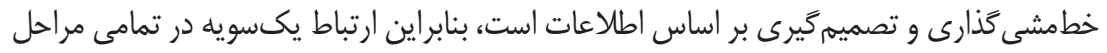
خطمشى تذارى اثر كذار است. در مشاركت نوع دوم با عنوان مشاوره اجتماعى در קنج مرحله خرخه خطمشى گذارى مشمول

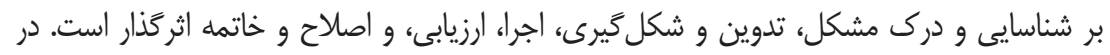

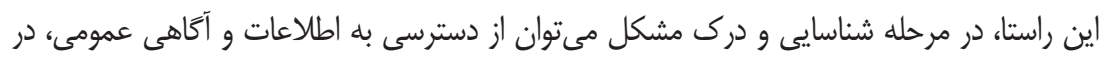

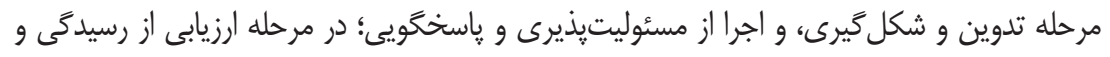

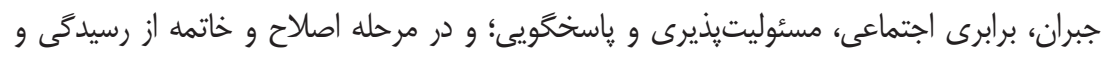

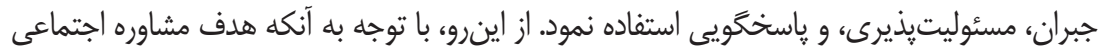

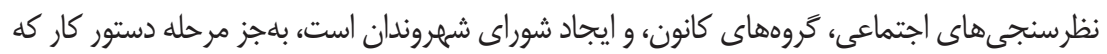

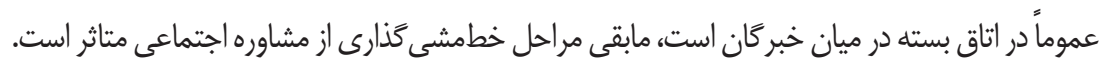


در مشار كت نوع سوم با عنوان ديالوكَ و كَفتكوى عميق در شش مرحله، خرخه خطمشى گذارى

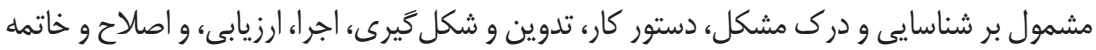

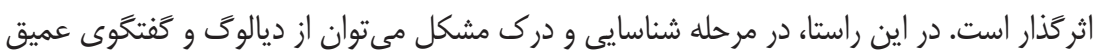

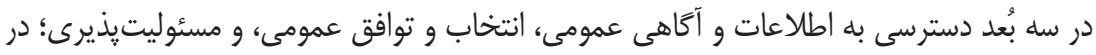

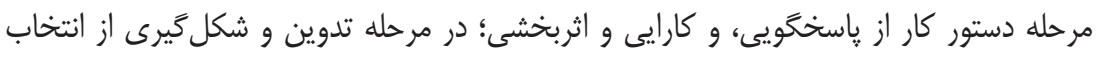

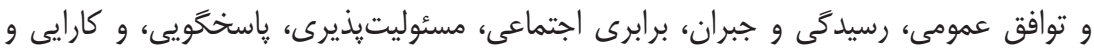

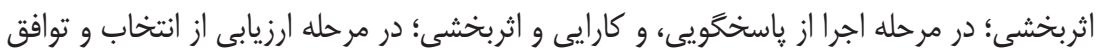

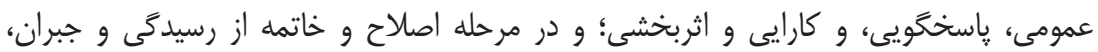

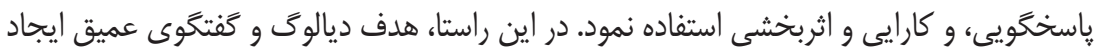

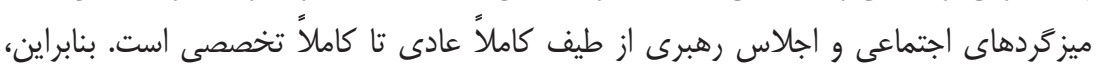

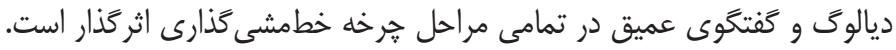

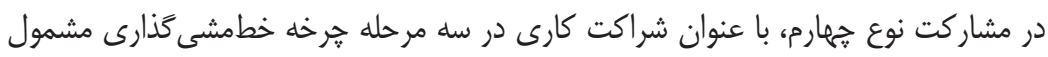

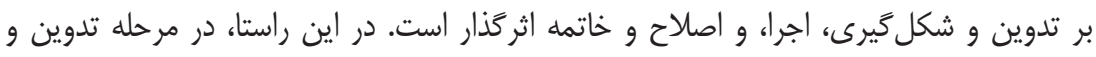

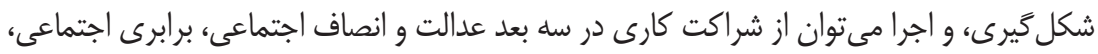

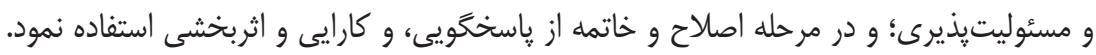

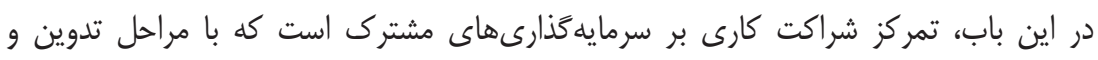
شكل كيرى، اجرا، و اصلاح و خاتمه مرتبط است.

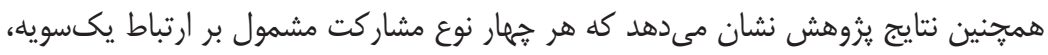

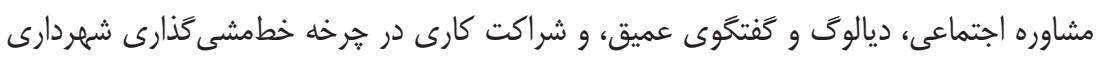

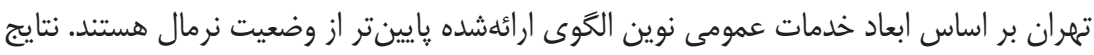

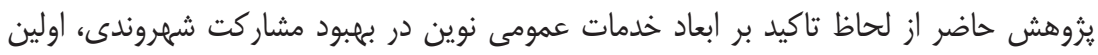

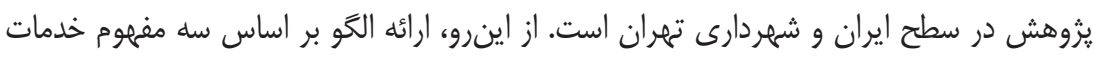

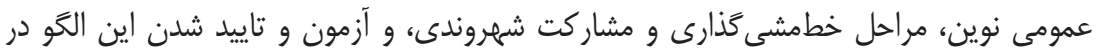

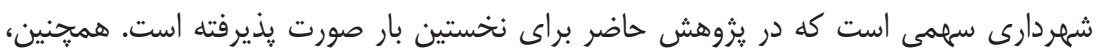
مشخص نمودن اولويت انواع مشاركت شهروندى با ارتباط ابعاد خدمات عمومى نوين و مراحل

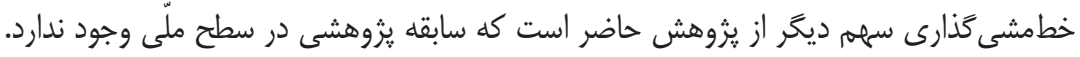

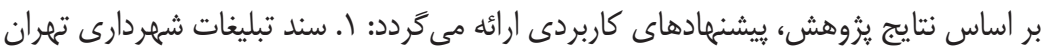

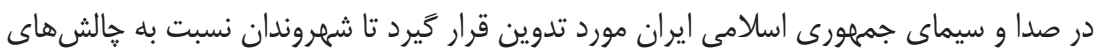


مديريت شهرى و خدمات و فعاليتهايى كه شهردارى ارائه مى كند آشنا شوند و اطلاعات و

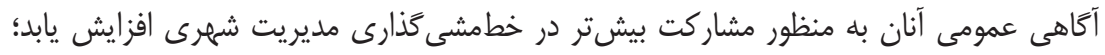

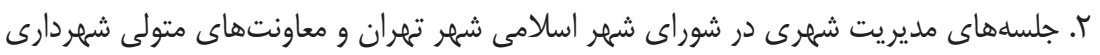

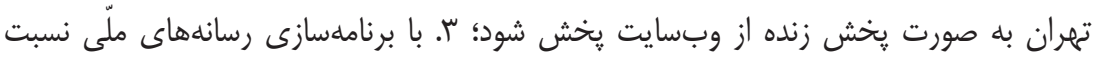

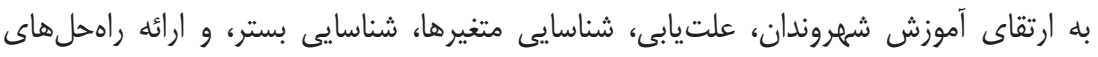

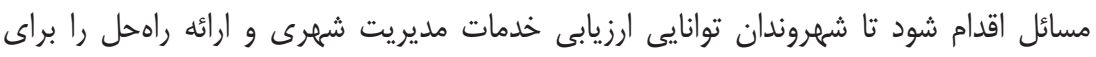

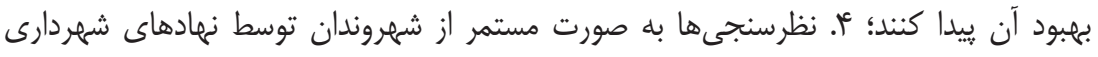

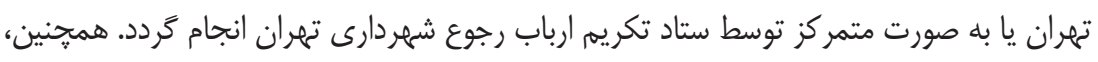

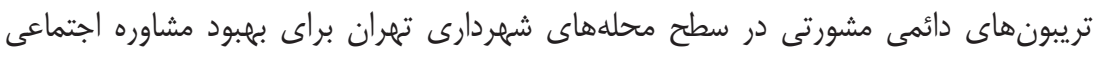

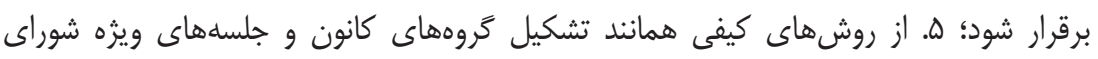
شهروندى (مشاورهاى اجتماعى) استفاده گَردد و در كانونهاى ارزيابى، مديران ارشد شهردارى

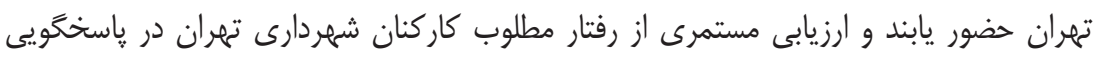

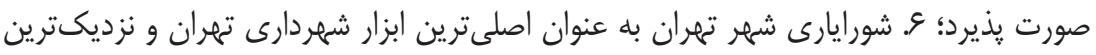

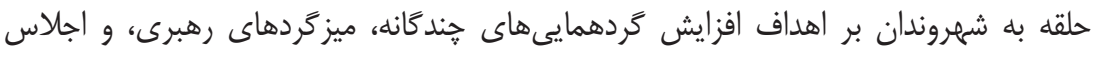

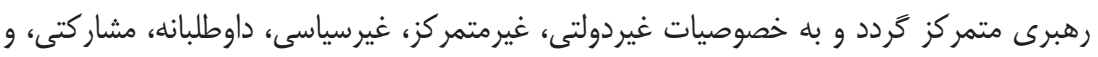

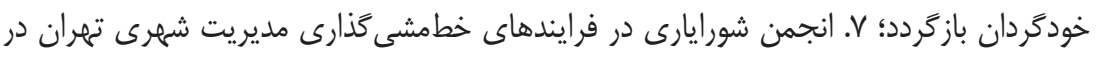

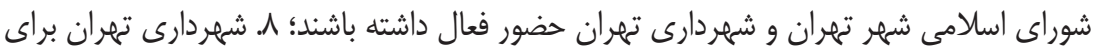

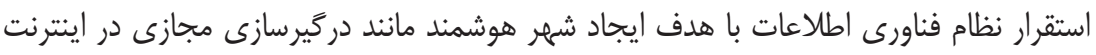

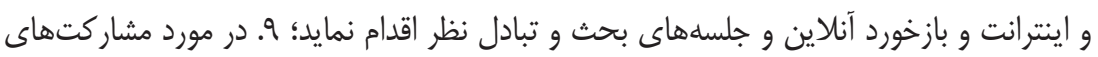

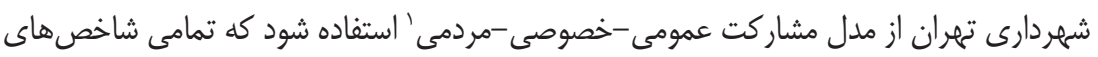

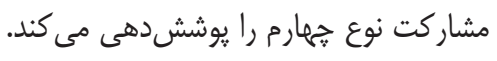

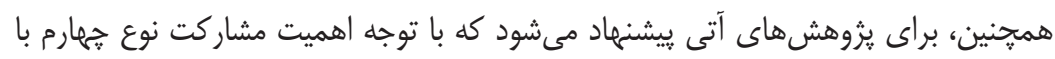

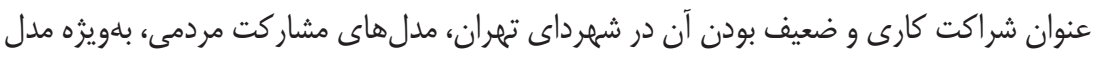

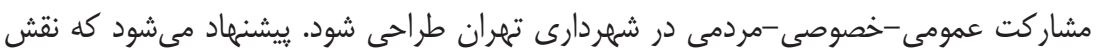

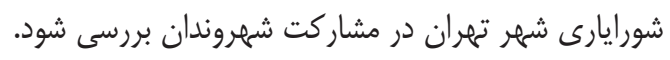

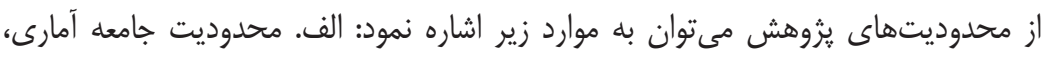

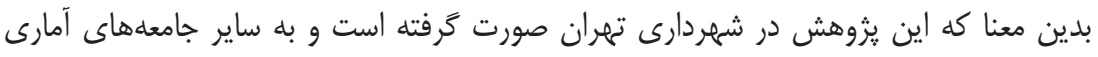

1. Public_Private_People Partnership 
تعميميذير نيست؛ ب. در نظر نخَرفتن متغيرهاى كنترل در ثروهش؛ ج. انجام ندادن آزمونهاى تناسب مدل و بارهاى عاملى يرسشها؛ و د. اجرا نكردن آزمونهاى مشخص كننده خطاى روش مشترى يس از جمع آورى دادهها.

\section{منابع}

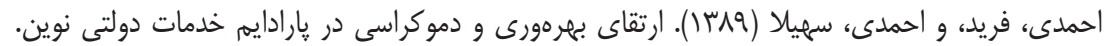

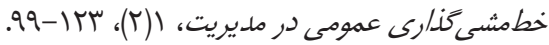

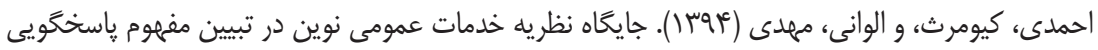

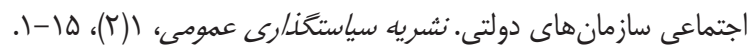

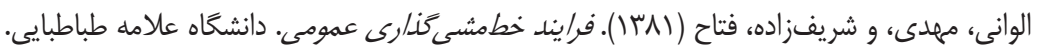

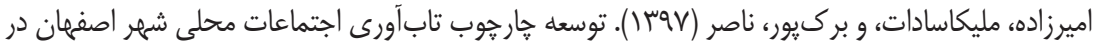

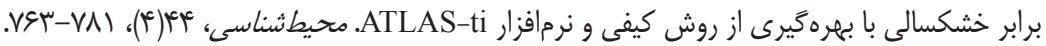

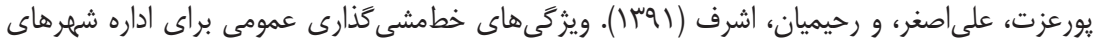

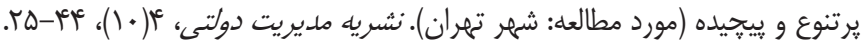

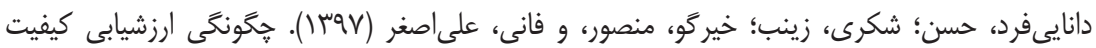

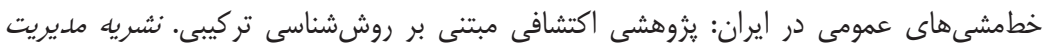

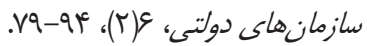

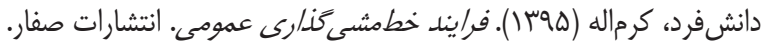

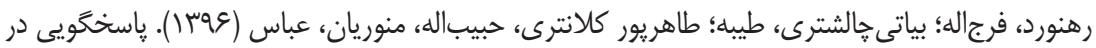

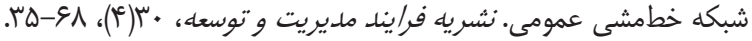

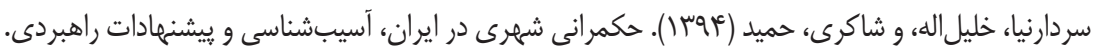

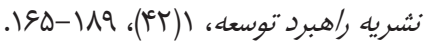

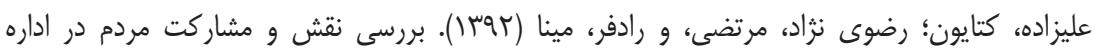

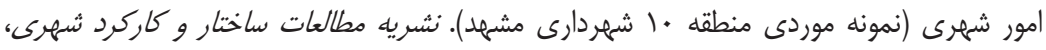

$$
\text { S)-AV،(I)) }
$$

قنبرى، حبيب (1) (1). مديريت رفتار سازمانى. دوره عالى مر كز آموزش امام مهدى (عج) ساحفاناجا.

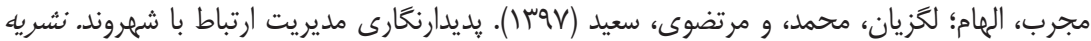

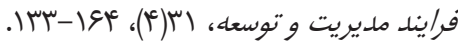
مكوندى، فواد، و رضايى، اسماعيل (Vوسا). بررسى و تحليل شكاف نقشه راهي راه اصلاح نظام ادارى با 

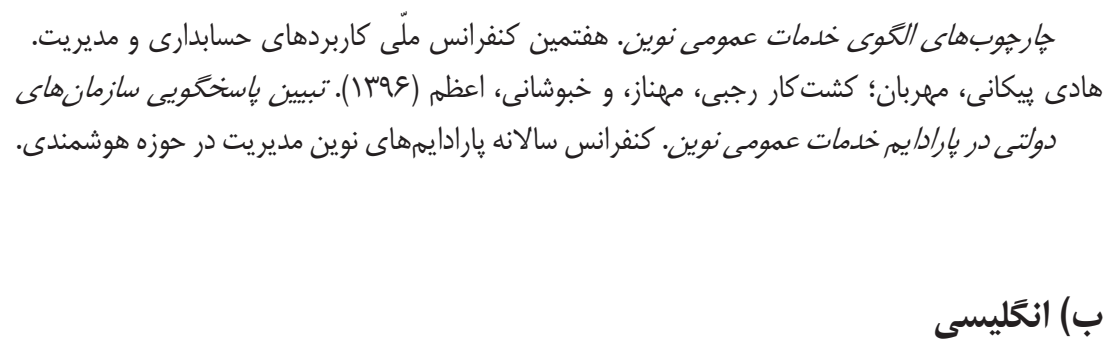

Alamsyah, K. (2019). Community Satisfaction to Regional Public Hospital Banjar City, Indonesia.international knowledge sharing paltform.7(5).

Beise-Zee, R. (2011). Corporate Social Responsibility or Cause-Related Marketing? The Role of Cause Specificity of CSR. Journal of Consumer Marketing, 28(1), 27-39.

Bell, D. E., \& Shelman, M. L. (2011). KFC's Radical Approach to China. Harvard Business Review, 89(11), 137-142.

Brown, T. L., \& Potoski, M. (2003). Contract-Management Capacity in Municipal and County Governments. Public Administration Review, 63(2), 153-164.

Bryson, J. M., Crosby, B. C., \& Bloomberg, L. (2014). Public Value Governance: Moving Beyond Traditional Public Administration and the New Public Management. Public Administration Review, 74(4), 445-456.

Callahan, K. (2010). Next Wave of Performance Measurement: Citizen Engagement. Connected/Communities, ed. James Svara and Janet V. Denhardt, 95-101.

Cheng, J.-H., Lee, C.-M., \& Tang, C.-H. (2009). An Application of Fuzzy Delphi and Fuzzy AHP on Evaluating Wafer Supplier in Semiconductor Industry. WSEAS Transactions on Information Science and Applications, 6(5), 756-767.

Chung, S. Y. (2011). Fostering Citizen Participation trough Innovative Mechanisms In Governance, Policy, and Decision Making: Comparing Washington, DC And Seoul. Arizona State University.

Colgan, A., Rochford, S., \& Burke, K. (2016). Implementing Public Service Reform: Messages from the Literature (0992626919). Retrieved from Centre for Effective Services.

Davis, K. N. (2010). Exploring the Level of Public Participation in Planning: A Case Study Approach. Citeseer.

Denhardt, J. V., \& Denhardt, R. B. (2015). The New Public Service Revisited. Public Administration Review, 75(5), 664-672.

Gaynor, T. S. (2011). Stakeholder Perceptions on the Role of Community 
Development Corporations and Resident Participation. Rutgers UniversityGraduate School-Newark.

Hill, M., \& Hupe, P. (2014). Implementing Public Policy: An Introduction to the Study of Operational Governance: Sage.

Holmes, M. H. (2010). Translating Goals to Practice: An Analysis of US Army Corps of Engineers Public Participation Practices. Public Administration \& Management, 15(1), 177-220.

Muliawaty, D. L., SI, M., \& Muliawaty, L. (2019). The Role of New Public Service Model In Developing Tourist Destination In Bandung City: A New Paradigm For Domestic Tourism Industry. International Journal Of Scientific \& Technology Research, 8(6), 322-326.

Osborne, D., \& Gaebler, T. (1992). Reinventing Government: How the Entrepreneurial Spirit is Transforming the Public Sector: Prentice Hall of India.

Partridge, K., Jackson, C., Wheeler, D., \& Zohar, A. (2005). From Words to Action: The Stakeholder Engagement Manual-Volume 1 The Guide to Practioners' Perspectives on Stakeholder Engagement: Cobourg: AccountAbility, UNEP and Stakeholder Research Associates.

Pierce, E. L. (2011). Citizen-Informed Performance Measurement and Reporting in Local Government: Key Factors for Effective Democratic Governance. (Doctor of Philosophy), Western Michigan University.

Raadschelders, J. C., \& Lee, K. H. (2011). Trends in the Study of Public Administration: Empirical and Qualitative Observations from Public Administration Review, 2000-2009. Public Administration Review, 71(1), 19-33.

Reed, C. M., \& Meyer, K. P. (2004). Medicaid Managed Care for Children with Special Health Care Needs: Examining Legislative and Judicial Constraints on Privatization. Public Administration Review, 64(2), 234-242.

Rho, E. (2013). Contracting Revisited: Determinants and Consequences of Contracting out for Public Education Services. Public Administration Review, 73(2), 327-337.

Riccucci, N. M., \& Thompson, F. J. (2008). The New Public Management, Homeland Security, and the Politics of Civil Service Reform. Public Administration Review, 68(5), 877-890.

Roblek, V., Bach, M. P., Meško, M., \& Bertoncel, T. (2020). Best Practices of the Social Innovations in the Framework of the E-Government Evolution. Amfiteatru Economic, 22(53), 275-302.

Romzek, B. S., \& Johnston, J. M. (2005). State Social Services Contracting: Exploring the Determinants of Effective Contract Accountability. Public Administration Review, 65(4), 436-449. 
Strokosch, K., \& Osborne, S. P. (2020). Debate: If Citizen Participation Is So Important, Why Has It Not Been Achieved? Public Money \& Management, 40(1), 8-10.

Taylor, J. (2006). Performance Measurement in Australian and Hong Kong Government Departments. Public Performance \& Management Review, 29(3), 334-357.

Terry, L. D. (2005). The Thinning of Administrative Institutions in the Hollow State. Administration \& Society, 37(4), 426-444.

Übius, Ü., \& Alas, R. (2009). Organizational Culture Types as Predictors of Corporate Social Responsibility. Engineering Economics, 61(1), 90-99.

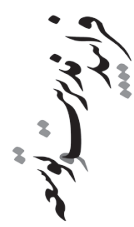

7
2
0
2
2
1
3
$\vdots 3$
0
5
1
3
3
0
2
1
3
0
0
\pm 